\title{
Palaeoecology and biostratigraphy of the Paleogene Foraminifera from the southern Upper Rhine Graben and the influence of reworked planktonic Foraminifera
}

\author{
by \\ Claudius Pirkenseer, Silvia Spezzaferri \& Jean-Pierre Berger
}

with 18 plates, 25 text-figures, 1 table and 1 appendix

\begin{abstract}
Summary
Two cores and several field outcrops covering the entire Paleogene succession of the southern Upper Rhine Graben were studied and sampled in detail. 270 samples were subsequently examined for their microfossil content. This study focuses on recording, palaeoecological interpretation and illustration of the Foraminifera assemblages (180 taxa). Additionally, other fossil groups were documented including Charophyta, fish otoliths, Bolboforma and calcareous nannoplankton. From the occurrence and distribution patterns of these groups palaeoenvironmental and palaeogeographic implications were deduced.

While the Eocene succession contains hardly any fossils, the two Rupelian transgression-regression cycles ("Zone fossilifere", "Série grise") in the Upper Rhine Graben can be well traced by their respective microfossil assemblages. Both transgressions start off with fully marine outer shelf to upper bathyal Foraminifera assemblages. In both cases maximum flooding is reached early in the sequence cycle. During the second Rupelian transgression the benthic and small sized planktonic Foraminifera associations indicate cold to temperate water temperature. While generally well-oxygenated bottom waters and sediments prevailed during the initial phase ("Marnes à foraminiferes"), the situation abruptly changed to suboxic and anoxic conditions during the subsequent deposition of the "Schistes à poissons". This led to a drastic drop in diversity and abundance of benthic Foraminifera species in this interval.

The corresponding regressive phase of the "Série grise" is characterised by a thick interval dominated by planktonic Foraminifera ("Couches à Mélettes") and a reappearance of benthic assemblages in the terminal unit ("Marnes à Cyrènes").

The biostratigraphic data derived from planktonic Foraminifera assemblage ranges is distorted by simultaneously occurring facultatively reworked Eo-Oligocene ranging species. The most conservative age-estimation implies an attribution to the Mid P20 to P21a plankton-zones for the "Série grise" deposits. This corresponds to less precise ages indicated by calcareous nannoplankton, Charophyte assemblages and fish otoliths.

Abundant reworked, mainly Cretaceous and Lutetian to Priabonian planktonic Foraminifera from the Late Rupelian "Série grise" are documented, figured and interpreted in relation to similar occurrences in the northern part of the Upper Rhine Graben and the Mainz Basin.
\end{abstract}

Due to the absence of time-equivalent marine Eocene deposits in the Upper Rhine Graben itself the planktonic Foraminifera are supposed to be reworked from the alpine domain by a northwards trending fluviatile drainage system.

Key words: Paleogene - Foraminifera - palaeoecology - biostratigraphy - reworking - southern Upper Rhine Graben

\section{Zusammenfassung}

270 Proben aus zwei Bohrkernen und verschiedene Aufschlüsse, welche die komplette paläogene stratigraphische Abfolge des südlichen Oberrheingrabens abdecken, wurden auf ihren Mikrofossilinhalt untersucht. Die vorliegende Studie erfasst und klassifiziert die darin vorkommenden Foraminiferen (180 Taxa). Darüber hinaus wurden weitere Fossilgruppen wie Charophyten, Fischotolithen, Bolboforma und kalkiges Nannoplankton erfasst. Die aus der Verteilung aller bestimmten Fossilgruppen abgeleiteten paläoökologischen und paläogeographischen Informationen wurden in die Interpretation der paläogenen Abfolge miteinbezogen.

Während die eozäne Abfolge sehr arm an Fossilien ist, lassen sich die zwei Rupeltransgressionen ("fossilreiche Zone", "Graue Serie") des Oberrheingrabens gut anhand ihres Mikrofossilinhalts nachvollziehen. Beide Transgressionen setzten mit Foraminiferenvergesellschaftungen des äußeren Schelfs bzw. des oberen Bathyals ein. Der relative Meerespiegel-Höchststand wird jeweils früh im

Claudius Pirkenseer, Dr. Silvia Spezzaferri and Prof. Jean-Pierre Berger, Department of Geosciences, University of Fribourg, Chemin du Museé 6, Perolles, 1700 Fribourg, Switzerland 
Sequenz-Zyklus erreicht. Während der zweiten Rupeltransgression weisen die benthischen und kleinwüchsigen planktonischen Foraminiferenassoziationen auf kalte bis gemässigte Wassertemperaturen hin. Generell gute Sauerstoffsättigung des Tiefenwassers und der oberen Sedimentschichten während der initialen Phase der zweiten Rupeltransgression ("Foraminiferenmergel”) wechselt abrupt zu schwach gesättigten bis anoxischen Verhältnisse in den darauf folgenden "Fischschiefern" mit einer stark reduzierten Foraminiferenfauna.

Die anschließende regressive Phase der "Grauen Serie" ist durch ein mächtiges, durch planktonische Foraminiferen dominiertes Intervall ("Meletta-Schichten") und das Wiederauftreten signifikanter benthischer Assoziationen in der letzte Einheit ("Cyrenenmergel”) gekennzeichnet.

Das Vorkommen von fakultativ umgelagerten planktonischen Foraminiferenarten mit einer vom Eozän in das Oligozän reichenden stratigraphischen Reichweite verzerrt die biostratigraphische Interpretation. Die konservativste Einschätzung ordnet die Ablagerungen der "Grauen Serie" den Planktonzonen Mittlere P20 bis P21 zu. Letzteres stimmt grob mit den aus dem kalkigen Nannoplankton, den Charophytenassoziationen und den Fischotolithen gewonnen biostratigraphischen Altern überein.

Häufig vorkommende, aus der späten Kreide und dem Lutet bis Priabon umgelagerte planktonische Foraminiferen der "Grauen Serie” sind dokumentiert und im Vergleich mit ähnlichen Vorkommen aus dem nördlichen Oberrheingraben und dem Mainzer Becken paläogeographisch interpretiert.

Das Fehlen von autochthonen kreidezeitlichen und eozänen marinen Sedimenten im Bereich des Oberrheingrabens legt eine Umlagerung der planktonischen Foraminiferen durch ein nordwärts gerichtetes Flusssystem aus dem alpinen Bereich nahe.

Schlüsselwörter: Paläogen - Foraminiferen - Paläoökologie - Biostratigraphie - Umlagerung - südlicher Oberrheingraben

\section{Contents}

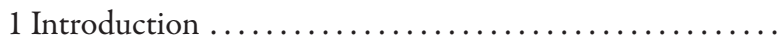

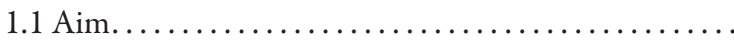

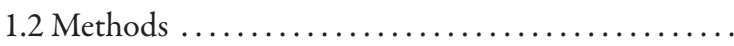

2 Geologic context and Paleogene evolution .............

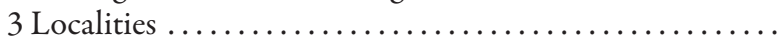

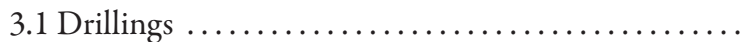

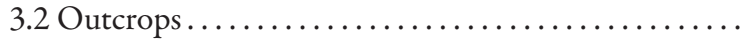

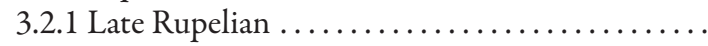

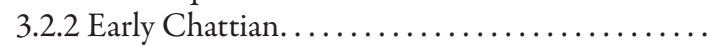

4 Taxonomical notes Foraminifera $\ldots \ldots \ldots \ldots \ldots \ldots \ldots$

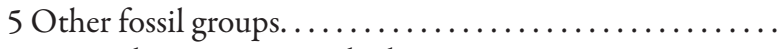

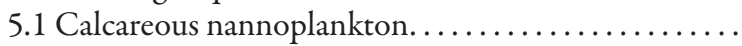

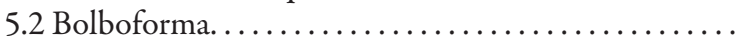

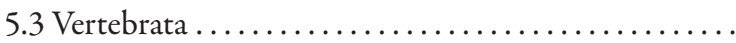

6 Biostratigraphy ...

6.1 Calcareous nannoplankton, fish otoliths,

Charophyta, Ostracoda....................

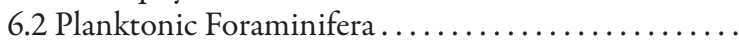

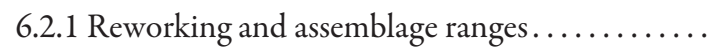

6.2.2 Possible models of assemblage ranges .........

6.2.3 Evaluation of the most likely range linked

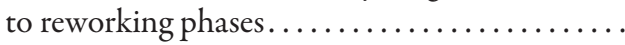

6.2.4 Conclusions.........................

7 Reworking of Cretaceous and Paleogene Foraminifera ...

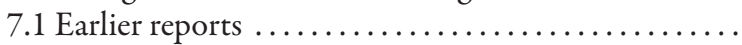

7.1.1 Upper Rhine Graben and adjacent northern

and eastern areas. .

\section{Introduction}

\subsection{Aim}

The rift of the Upper Rhine Graben (between Freiburg i. Br., Colmar, Montbéliard and Basel) provides an interesting field for palaeogeographic, palae-
7.1.2 Jura Molasse (NW Switzerland) ...........

7.1.3 Molasse Basin and northern Alpine margin ....

7.2 This study $\ldots \ldots \ldots \ldots \ldots \ldots \ldots \ldots \ldots \ldots \ldots \ldots$

7.2.1 Stratigraphic distribution of the reworked material in the research area ..............

7.2.2 Magnitude and range of reworked

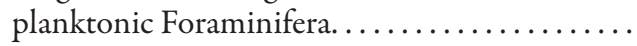

7.3 Discussion of source areas...................

7.3.1 Cretaceous............................

7.3.2 Paleogene ............................

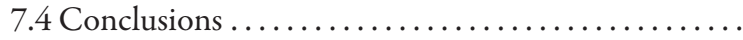



8.1 The "Zone Fossiliferre" (Early Rupelian) .........

8.2 The lowermost "Série grise":

"Marnes à foraminiferes" (Late Rupelian) ...

8.3 The lower "Série grise": "Schistes à poissons"

(Late Rupelian) ....

8.4 The middle "Série grise": "Couches à Mélettes"

(Late Rupelian)...

8.5 The upper "Série grise": "Marnes à Cyrènes"

(Late Rupelian).

9 Palaeogeography.

10 Summary ...

11 Acknowledgements

12 References....

13 Appendix: Foraminifera species list

oecologic, tectonic and sedimentary analyses. During the Cenozoic the area was characterized by an alternately either isolated or connected situation. While several comprehensive publications have dealt with aspects of regional geology, lithostratigraphy, palynology, palaeoenvironment, tectonics and sedimentology 
as well as special fossil groups (e.g., DURINGER 1988, Pharisat 1991a, Schuler 1990, Sittler 1965, STORNi 2002, UsTASZEWSKI 2004), work on microfossils from the research area has generally been of limited extent or concerns deposits of adjacent areas like the Swiss Jura Molasse (e.g., Huber 1994, Oertli 1956, Рісот 2002). Furthermore, only few biostratigraphic age determinations have been obtained for the southern Upper Rhine Graben (see BERGER et al. 2005b).

This study aims at a complete stratigraphic overview and record of Tertiary microfossils and their palaeoecologic, palaeogeographic and taxonomic implications and is based on the PhD thesis Pirkenseer (2007). The correlation of the fossil assemblages with the two Rupelian Upper Rhine Graben transgressions and the role of the abundant reworked planktonic Foraminifera are of special interest. Improving the known biostratigraphic framework represents a further objective. The results of the additional fossil groups will be covered in a subsequent volume. A recently compiled analysis and an interpretation of the sedimentological architecture of the research area by Roussé (2006) have been integrated into this study. To obtain a maximum of stratigraphic coverage, two drill cores (Allschwil-2, DP-202) covering the entire Lutetian to Chattian succession were chosen for investigation in addition to several field outcrops.

\subsection{Methods}

Each samples taken from the drilling DP-202 and the various outcrops weighed between 1 and $3 \mathrm{~kg}$. In order to obtain a maximum number of microfossils, only small reference samples were put aside. The sediment was treated with hydrogen peroxide at concentrations between $10 \%$ and $25 \%$, dependent on the solubility of the material. Samples were wet-sieved through $63 / 125 / 250 / 500 / 1000 \mu$ meshes to remove the mud fraction. The residues were then airdried at $50^{\circ} \mathrm{C}$.

To obtain a maximum diversity of the microfossil assemblages, the whole fractions from 250-1000 $\mu$ (except for the quartz rich sandstones) and a justifiable amount of the 63-125 $\mu$ material was generally picked under a binocular microscope (Zeiss SV11, Nikon SMZ1500). Nevertheless, some species are only represented by one or few specimens (e.g., Marginulina hirsuta, Lagena gracilicosta). In fractions showing no microfossils seven picking dishes were checked before dismissing the sample.
The samples derived from the Allschwil-2 core were forwarded as already washed and partly separated dry residues. Microfossils in samples with higher clastic content were enriched by gravity separation methods (chemicals unknown).

Figured specimens were coated with gold (thickness depending on specimen) and then photographed with a FEI XL30 Sirion FEG scanning electron microscope generally at maximum resolution with spot size 5 and $20 \mathrm{kV}$ acceleration voltage. The size of the specimens was either measured directly during the scanning or via an ocular micrometer calibrated with a Zeiss glass microscale.

\section{Geologic context and Paleogene evolution}

The Upper Rhine Graben represents the central part of the European Continental Rift System (ECRIS) and extends about $300 \mathrm{~km}$ on an approximately North-South axis between the cities of Wiesbaden (W Germany) and Basel (NW Switzerland).

Paleogene outcrops are generally found close to the Mulhouse Horst, along river valleys and near the graben margins. The main lithology is formed by medium to large-scale conglomerates of various origins. They were raised during the development of the graben and basement uplift on small horsts or on smaller fracture zones and thus provide the most common Paleogene outcrop locations (Text-fig. 1).

Towards the basin, the grain size diminishes considerably. The basin fill consists mainly of lacustrine to marine sands and marls, as well as the massive Potash salt deposits in the basin centre.

Neogene deposits are rare and far apart in the region South of Strasbourg, with the Miocene volcanics of the Kaiserstuhl penetrating the sedimentary cover.

The oldest preserved deposits date from the Lutetian. These restricted lacustrine limestones probably formed isochronous with the karstic Siderolithic Formation. They are overlain by the brackish "Marnes à Limnées" or the time-equivalent evaporitic "Zone salifere inférieure" of the pre-rifting stage (Textfigs. 2, 3).

The initial rifting phase in the Priabonian deepend the basin and increased the development of the marginal conglomeratic fans ("Steingang"). A further series of evaporites ("Zone Salifère moyenne") were deposited in the basin centre, rimmed by brackish to lacustrine marly sediments ("Marnes vertes", "Calcaires à Mélanies"). 


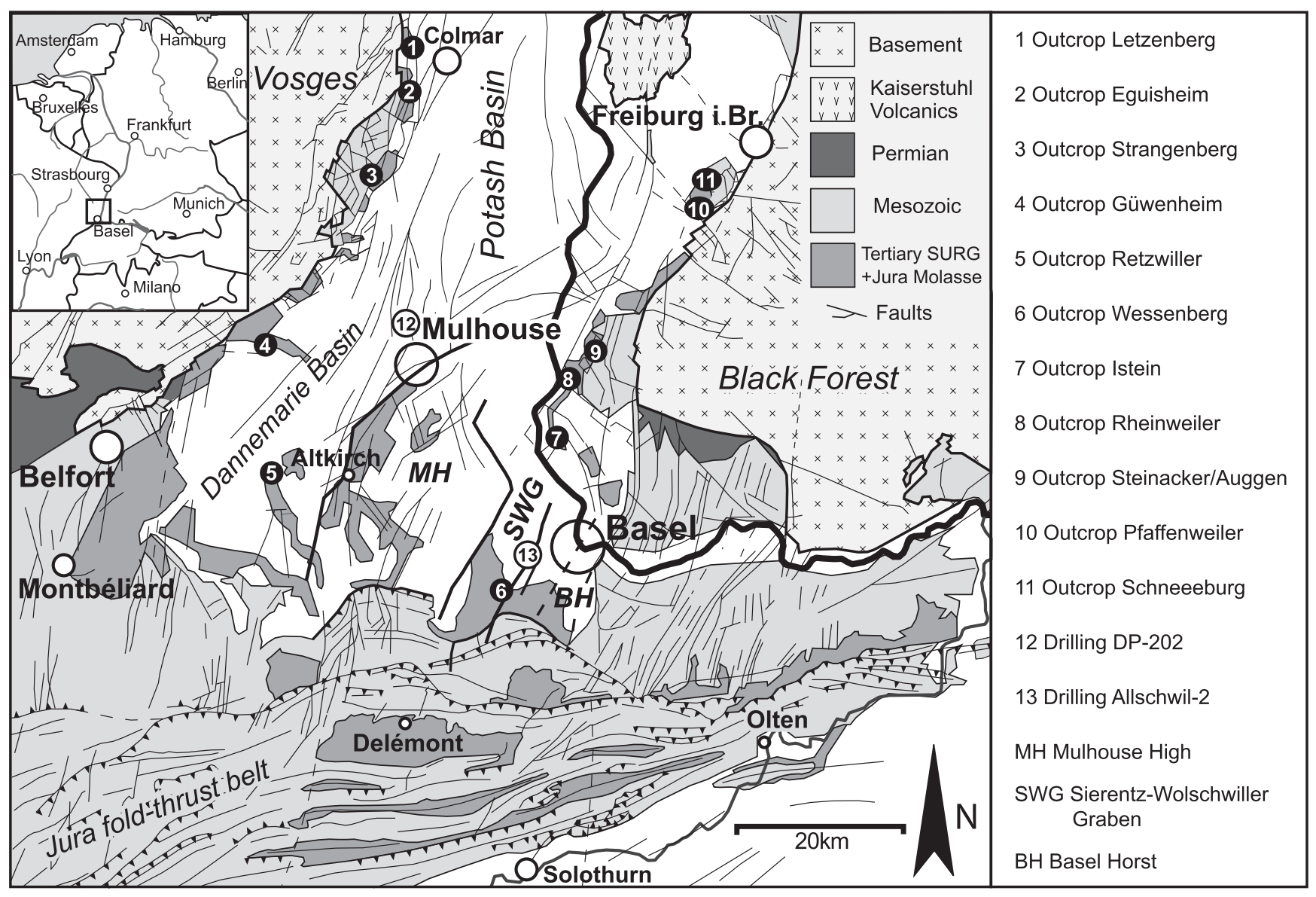

Text-fig. 1: Geologic and geographic overview of the research area.

At the base of the Oligocene the first Rupelian transgression invades the basin via the Hessian depression (Text-figs. 2, 3). This results in the deposition of the marly to calcareous, fossil-rich "Zone fossilifère". The transgression can also be traced in the marginal conglomerates wehre it is represented by several decimetres to meters thick marly intercalations. Near to and on the Mulhouse horst a time equivalent, but condensed series of organic rich laminar limestones and marls was deposited. The "Zone fossilifere" is overlain by the brackish to lacustrine "Haustein" or, depending on the region, by the "Zone Salifere supérieure".

The widespread second, "Middle" to Late Rupelian transgression affected the whole basin and led to the deposition of the several hundred meters thick "Série grise" (Text-figs. 2, 3). The fossil rich "Marnes à foraminiferes" and the more or less anoxic "Schistes à poissons" indicate fully marine conditions throughout the basin. The succeeding "Couches à Mélettes" consist of interbedded marls and fine to medium grained sandstones. The increasingly brackish and shallower "Marnes à Cyrènes" contain an abundant fauna and represent the last interval of the "Série grise". The transition from the "Couches à Mélettes" to the "Marnes à Cyrènes" is gradual.

According to BERGER et al. (2005b), the transgressions correspond to the Ru1 and Ru2-3 sequences (Neal \& Hardenbol 1998) respectively. The URG was most likely connected with the Paratethys during the second, Late Rupelian transgression.

The Latest Rupelian to Early Chattian fluvio-lacustrine Niederroedern Formation ("Molasse alsacienne") represents the last preserved Tertiary sediment series in the investigated area. 


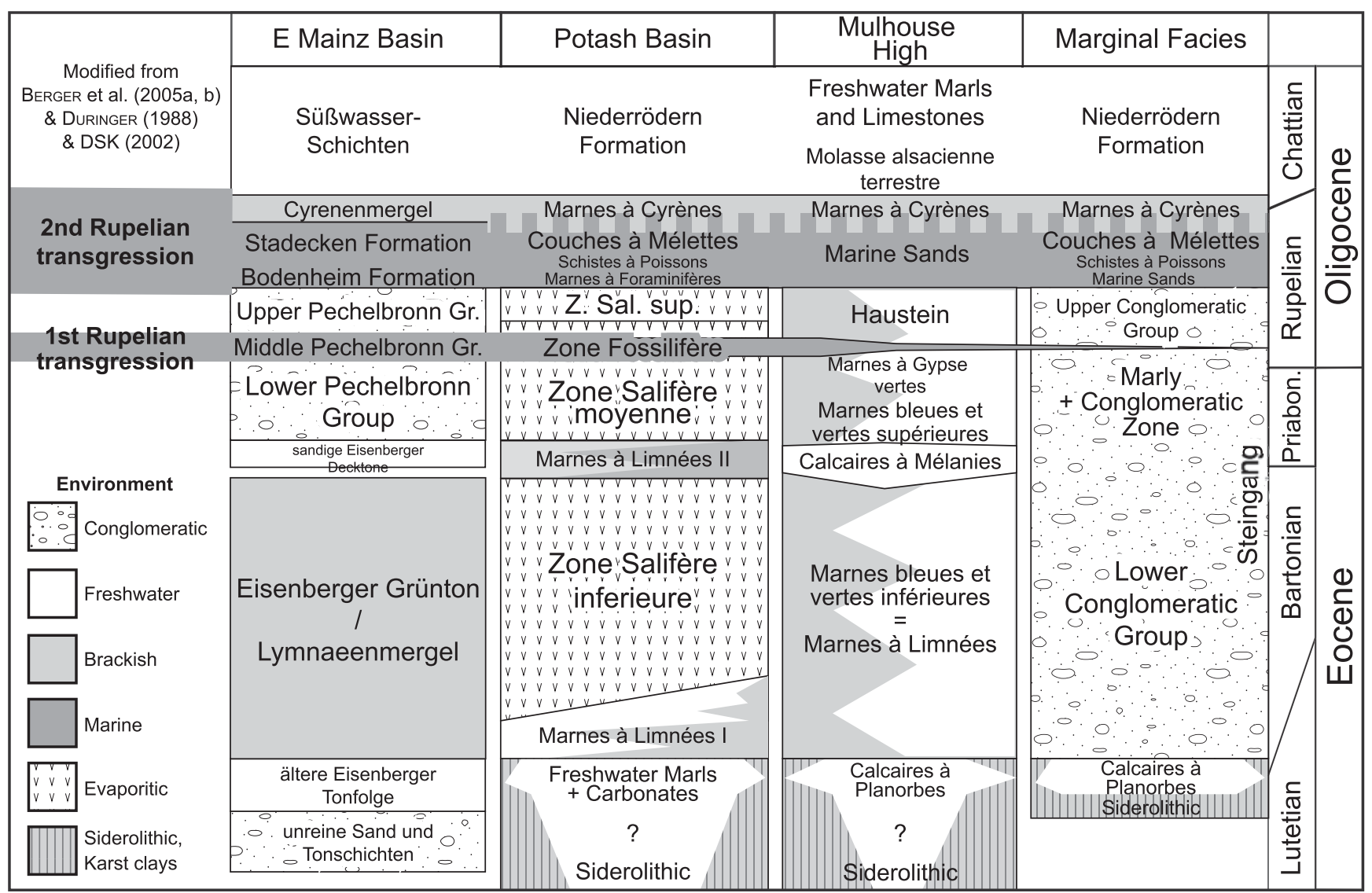

Text-fig. 2: Lithostratigraphic overview of the southern Upper Rhine Graben and the eastern Mainz Basin.

\section{Localities}

The field area for this study is located on the territory of three different countries; therefore three different graticules are involved. These are: the Swiss kilometric, the French Lambert II (L II) and the German Gauss-Krüger (G-K) coordinate systems.

\subsection{Drillings}

The Allschwil-2 (Swiss 605970/265825) drill site (Text-figs. 1, 4, 5) near the village Allschwil (SW of Basel, NW Switzerland) is situated close to the eastern margin of the Wolschwiller Graben and was completed in 1927. According to FisCHER et al. (1971), about $50 \%$ of a total of $922,1 \mathrm{~m}$ were cored. Of 282 existing samples from the core, about 130 were forwarded to the authors as already treated residues for picking and analyses. The drilling DP-202 (L II $971^{980} / 2327^{850}$ ) (Text-figs. 1, 6, 7) is located north of Mulhouse close to the centre of the Potash Basin. 91 samples were taken from the available, complete core between $721.7 \mathrm{~m}$ and $191 \mathrm{~m}$.

Foraminifera are recorded from the earliest Rupelian "Zone fossilifère" (rare, Allschwil-2) and throughout the "Série grise" (both drill cores). The highest diversity and abundance with more than 55 species and hundreds of specimens is reached in the "Marnes à foraminiferes", the basal lithological unit of the "Série grise". Throughout the subsequent "Schistes à poissons" and even more so the thick "Couches à Mélettes" diversity and abundance of Foraminifera is generally low. The occurrence of reworked Eocene and Late Cretaceous planktonic Foraminifera starts in both drill cores in the "Couches à Mélettes". In the "Marnes à Cyrènes", the final lithological unit of the "Série grise", the diversity and abundance of Foraminifera is again increasing. The combined palaeoecological results of both drill cores are discussed in chapter 7 . 


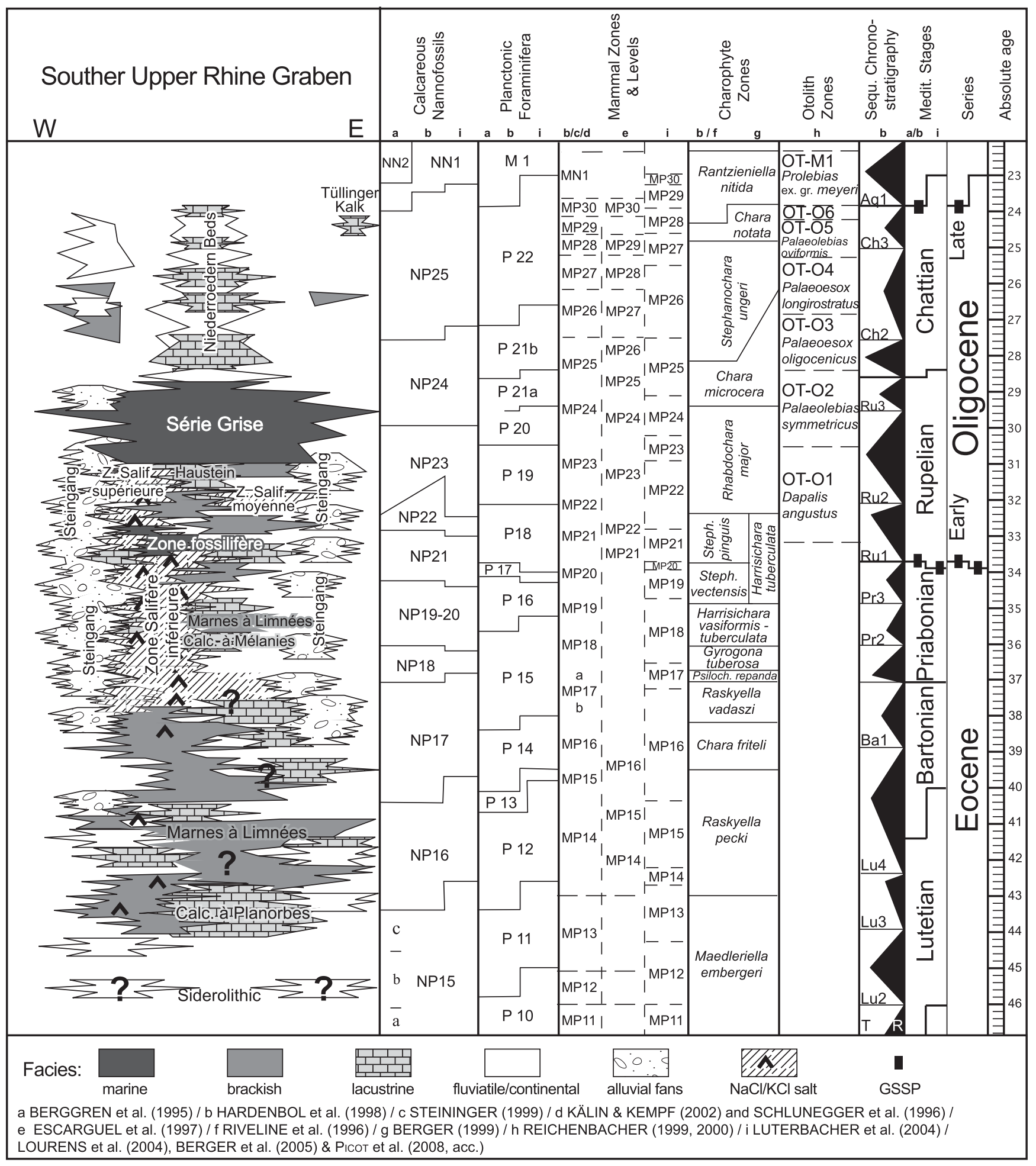

Text-fig. 3: Biostratigraphic overview in relation to international biozones and facies development of the research area. 


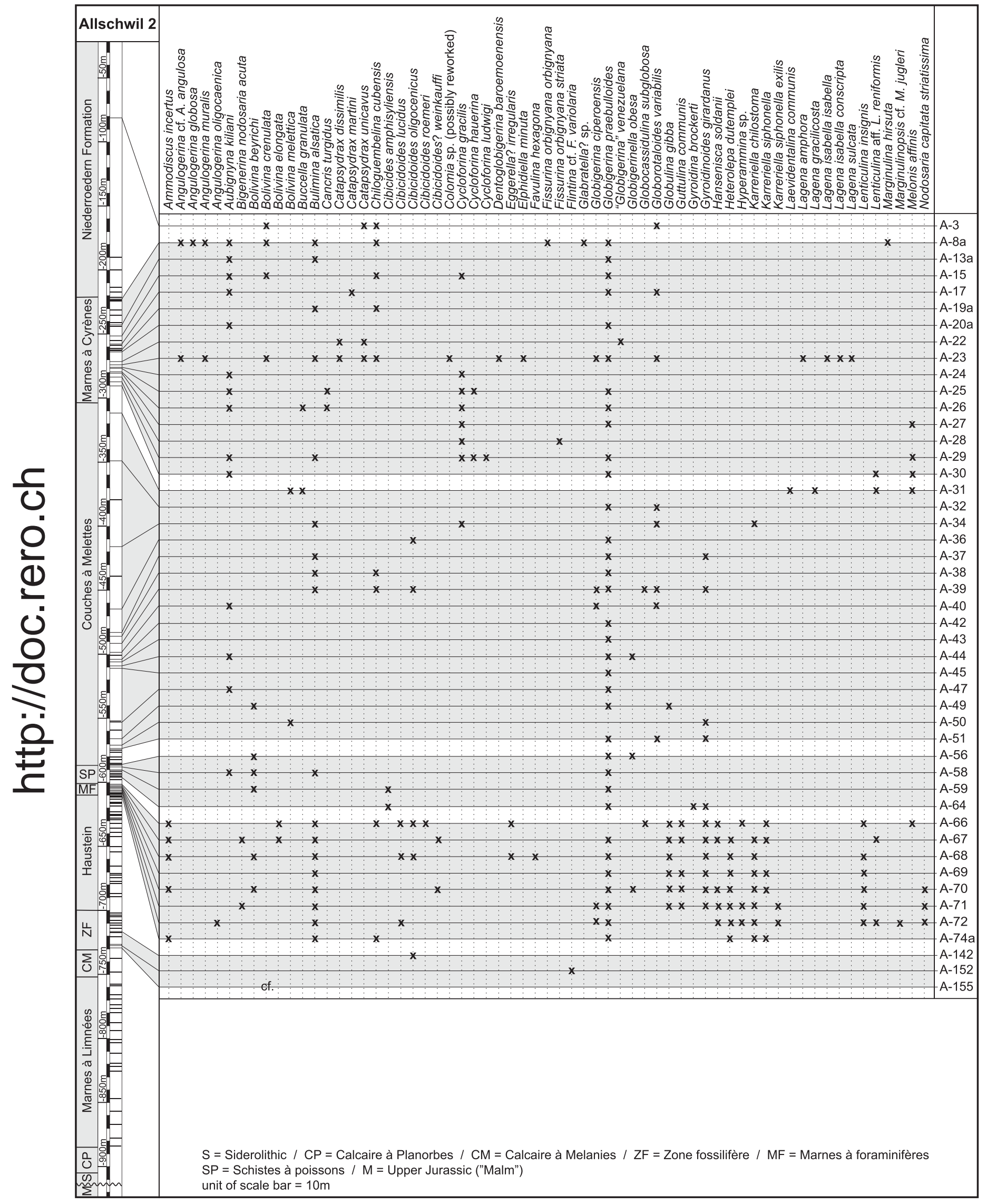

Text-fig. 4: Foraminifera range chart of the Allschwil-2 drill core (a). 


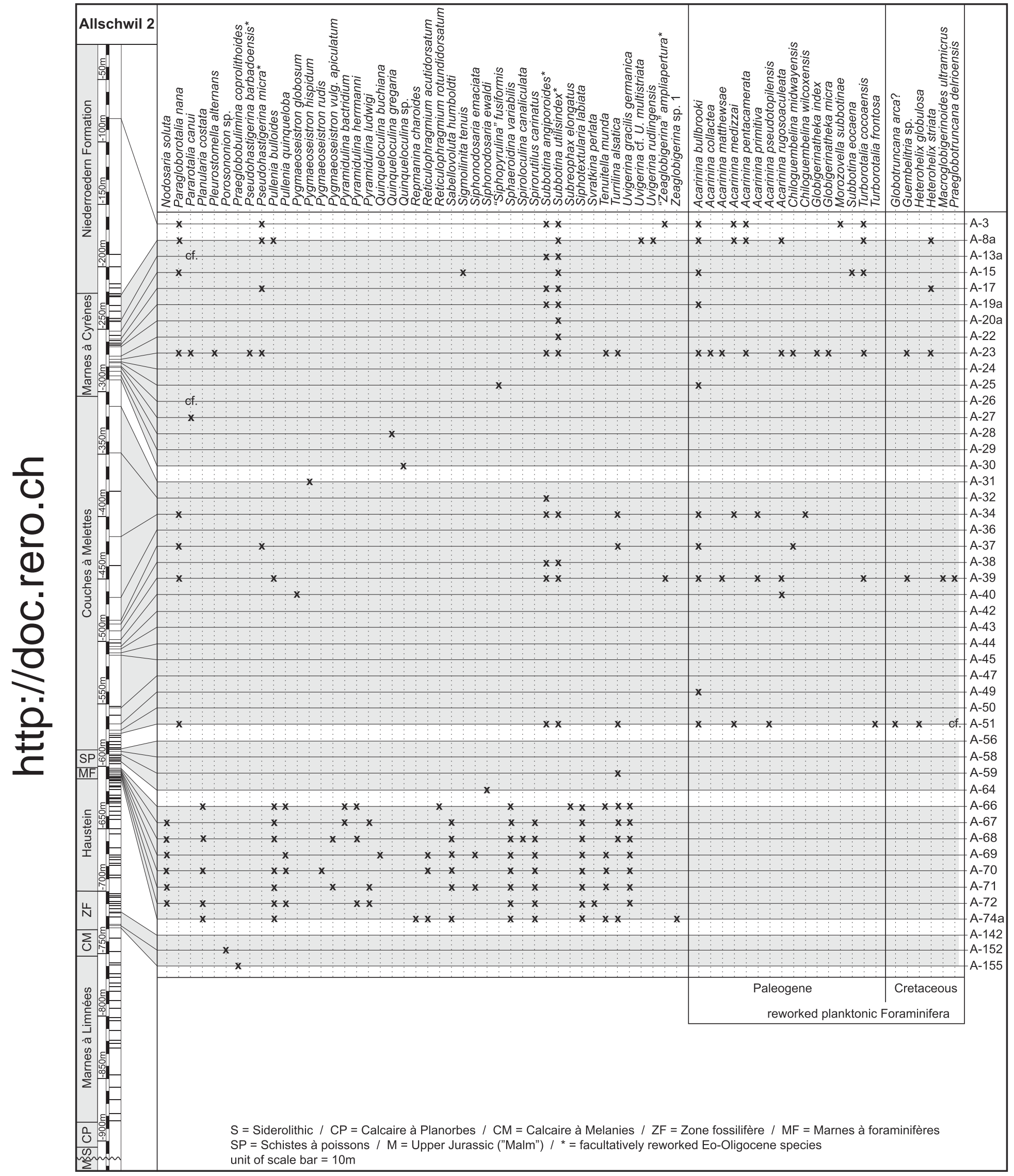

Text-fig. 5: Foraminifera range chart of the Allschwil-2 drill core (b). 


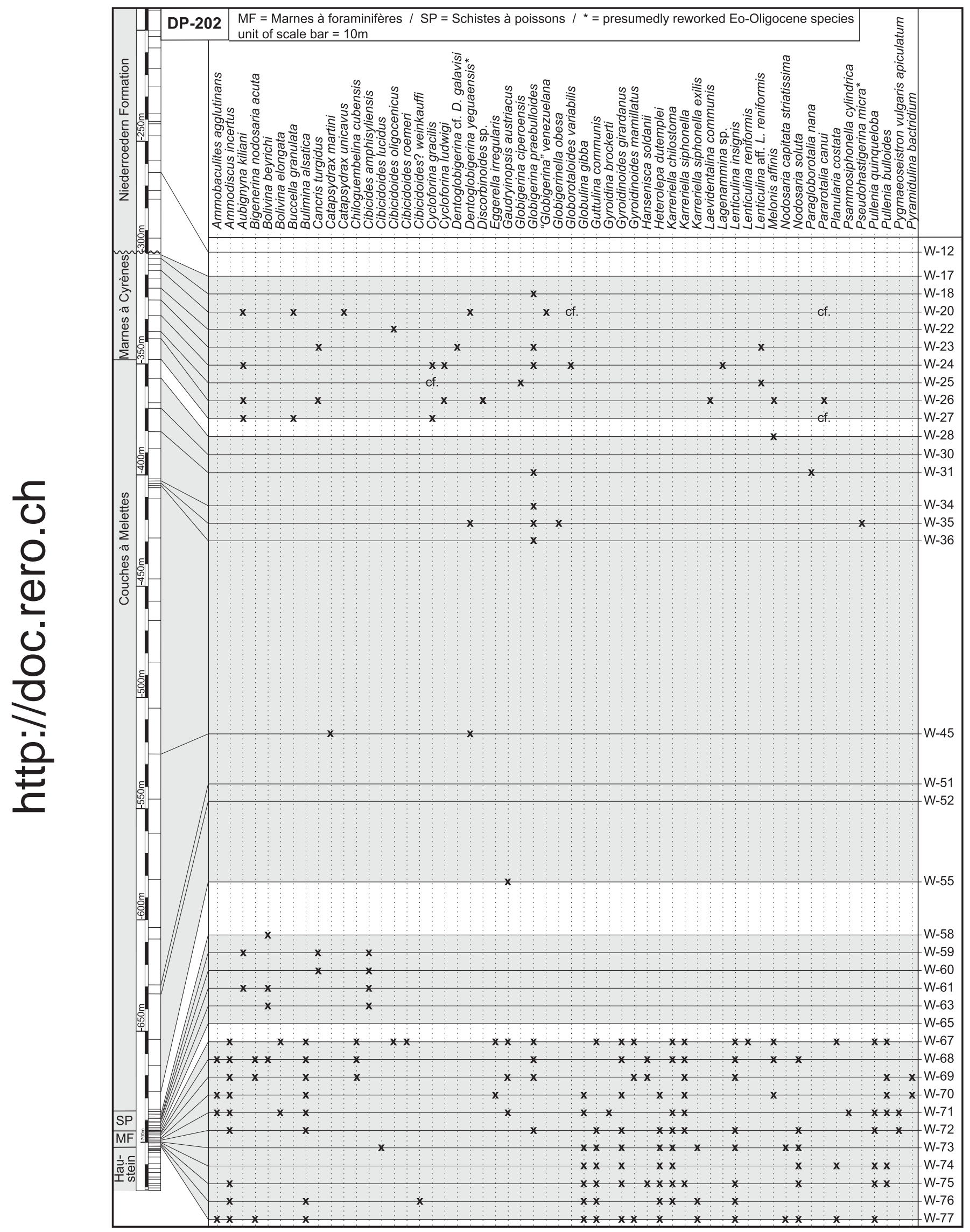

Text-fig. 6: Foraminifera range chart of the DP-202 drill core (a). 


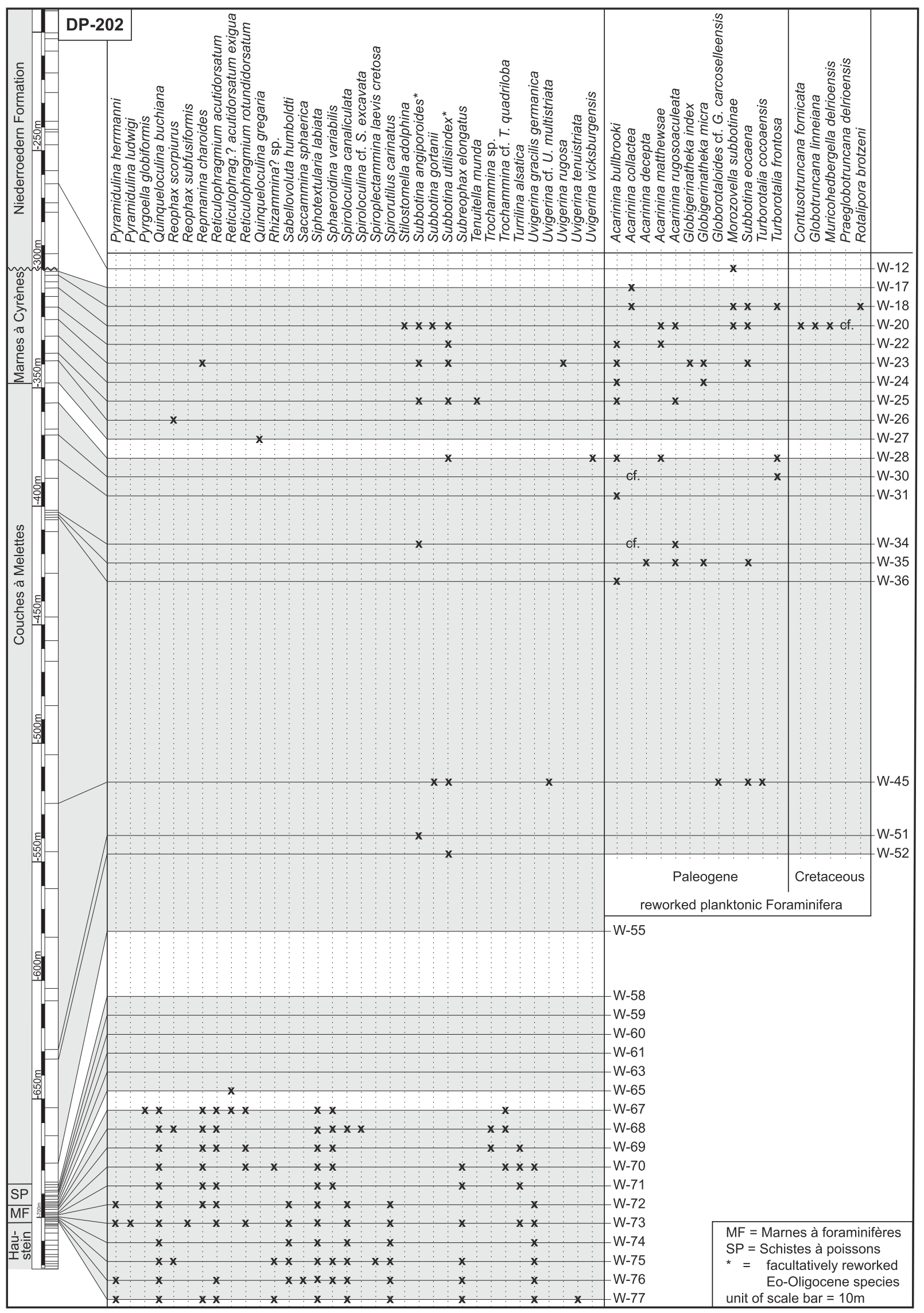

Text-fig. 7: Foraminifera range chart of the DP-202 drill core (b). 


\subsection{Outcrops}

\subsubsection{Late Rupelian}

Eguisheim (Text-fig. 8, western Graben shoulder, L II $970^{550} / 2349^{425}$ )

The large inactive quarry near is now used as vineyard and is situated 400 metres south of the village Eguisheim hidden behind a service causeway. Laterally a profile of about 7 metres of beige marls to platy discontinuous sandstones and massive coarse sands belonging to the "Marnes à foraminiferes" can be examined. Three samples from the marly facies of the western corner of the outcrop yielded an abundant and diverse benthic Foraminifera fauna indicating an outer shelf environment and cold to temperate water temperatures (see Text-fig. 20). A relatively rapid change between high-energy shoreface (Roussé 2006) and calm offshore deposits (below the storm wave base) occurs between $2.5 \mathrm{~m}$ and $3 \mathrm{~m}$ in the section. This is evidenced by the changing sedimentary architecture and the faunal assemblage in sample 3.

Rheinweiler (Text-fig. 9, eastern Graben shoulder, G-K $33^{90.550} / 52^{86.600}$ )

The small outcrop is at the end of a private road on the slope east of the village Rheinweiler (SW Germany). About 3 metres of schistoid black marls of the "Schistes à poissons" and about 3 metres of massive grey silty marls with small scale turbiditic fine sand layers (pro-delta facies A1; Roussé 2006) of the lowermost "Couches à Mélettes" crop out. Thin intermittent white layers are rich in coccolithophorids.

22 of 40 samples contained a lowly diverse but relatively abundant benthic Foraminifera assemblage (e.g., Bolivina beyrichi [Plate 7, figs. 3, 4], Cibicides amphisyliensis [Plate 10, fig. 2], Siphonodosaria ewaldi [Plate 9, fig. 2]) indicating suboxic to dysoxic bottom



Text-fig. 8: Eguisheim outcrop lithostratigraphic log and range chart. 


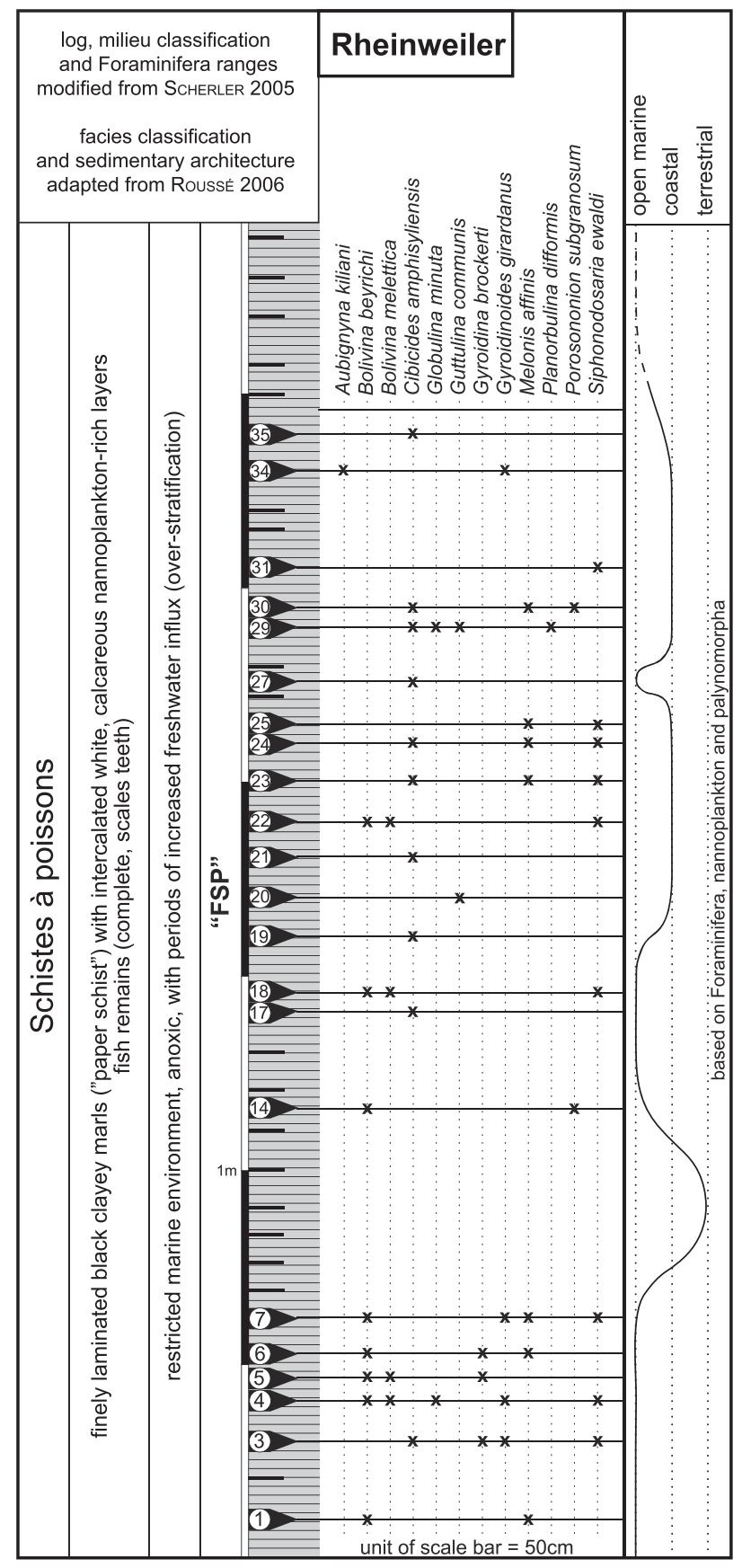

Text-fig. 9: Rheinweiler outcrop lthostratigraphic log and range chart.

conditions and outer shelf water depths (SCHERLER 2005). The samples gathered for this sudy yielded a similar fauna and very poorly preserved but abundant planktonic Foraminifera mainly of the Globigerina praebulloides group (Plate 16, figs. 2, 3).

Güwenheim (western Graben shoulder, 956 $750 / 2317^{300}$ )
The outcrop is located in the bed of the sream Doller, $1 \mathrm{~km}$ east of the small village of Güwenheim. The outcrop covers about 11 metres of grey silty marls and laminar and turbiditic sandstones, which have been attributed to the offshore/distal prodelta to distal delta-front facies (Roussé 2006) of the "Couches à Mélettes". 


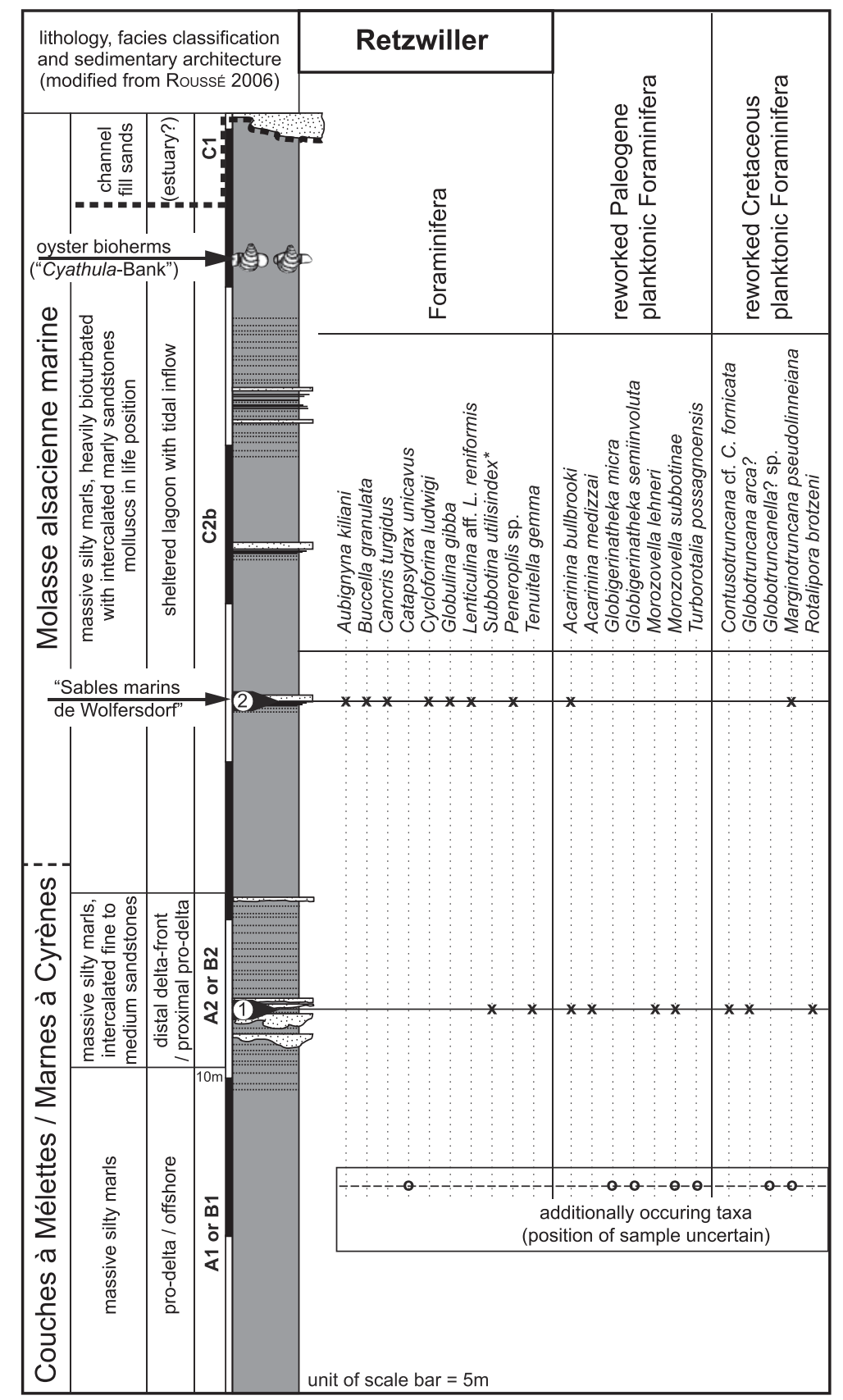

Text-fig. 10: Retzwiller outcrop lithostratigraphic log and range chart.

In the upper part of the profile abundant reworked Cretaceous and Eocene nannofossils and a few Eocene planktonic Foraminifera (e.g., Acarinina pentacamerata [Plate 14, fig. 1]) are recorded (SChERLER 2005). Further samples yielded the Late Eocene species Globigerinatheka semiinvoluta (Plate 15, fig. 4).

The rare benthic fauna comprises Bulimina alsatica (Plate 7, figs. 14, 15), Aubignyna kiliani (Plate 11, fig. 5), Porosononion sp. (Plate 10, fig. 4) and Lagena striata (SCHERLER 2005). A few autochthonous or possibly reworked planktonic species as Subbotina angiporoides (Plate 16, fig. 7), S. utilisindex (Plate 17, figs. 2, 3), Pseudohastigerina micra (Plate 17, fig. 6) and Paragloborotalia nana (Plate 17, fig. 8) are present.

Retzwiller (Text-fig. 10, Dannemarie Basin, L II $957^{950} / 2303^{750}$ ) 
The fenced-in and guarded clay pit west of the village Retzwiller presents the most extended outcrop within the upper "Série grise". The section covers about 40 metres of grey silty marls and intercalated sandstones related to pro-delta, sheltered lagoon and estuarine channel fill deposits (Roussé 2006).

The fauna derived from the distal delta-front sands in the lower part of the profile (sample 1) almost exclusively consists of reworked Cretaceous and Eocene planktonic Foraminifera. Sample 2 was obtained from the Mollusc-rich so called "Sables marins de Wolfersdorf" and yielded a shallow marine and relatively warm water benthic Foraminifera (e.g. Peneroplis sp. [Plate 5, fig. 2]) and Ostracoda assemblage. Low water energy is indicated by the presence of the ostracod Pterygocythereis ceratoptera.

\subsubsection{Early Chattian}

Wessenberg (L II 985 $550 / 2291^{550}$ )

The outcrop is located on the summit ridge of the Wessenberg between the villages Liebenswiller and Hagenthal-le-Haut (E France; Text-fig. 1). About $8 \mathrm{~m}$ of yellow silts, sands and irregularly platy sandstones crop out on the northern flank of the ridge. Only one sample contained benthic (Bulimina sculptilis [Plate 7, figs. 16, 17], Almaena osnabrugensis [Plate 10, fig. 8], Globocassidulina subglobosa [Plate 7, fig. 11], Melonis affinis [Plate 10, fig. 5]) and planktonic Foraminifera (e.g., Subbotina angiporoides [Plate 16, fig. 7], Zeaglobigerina ampliapertura [Plate 16, fig. 5], Catapsydrax sp.). Due to the poor state of preservation, the cooccurrence of reworked Cretaceous and Eocene planktonic Foraminifera like Globotruncana sp., Subbotina eocaena (Plate 16, fig. 8) and Turborotalia cerroazuelensis as well as the rather fluviatile character of the sediments the entire assemblage is considered to be reworked. Accordingly the profile is tentatively attributed to the "Molasse alsacienne continentale".

\section{Taxonomical notes Foraminifera}

The taxonomic arrangement of the Plates follows Cicha et al. (1998). For most genus and type descriptions the Ellis \& Messina online (http://micropress.org, part Foraminifera) and printed catalogues were consulted. BATjEs (1958), Cicha et al. (1998), Doebl \& Sonne (1974), Grimm (1994), Huber (1994), Kiesel (1970), ŁuCzKowska (1970), PAPP \& Schmidt (1985), Reiser (1987), Wenger
(1987) were employed to survey benthic Foraminifera of the Paratethys and the northwest European Paleogene. The determination of planktonic Foraminifera and the compilation of the range charts follow mainly Premoli Silva et al. (2003) and Premoli Silva, I. \& VERGA, D. (2004), with some updates derived from Huber et al. (2006). Taxonomical notes were only authored for not well-defined, controversial or aberrant taxa. For the stratigraphic distribution of each species and ecological parameters in the "Marnes à foraminiferes” see Text-figs. 4-7, 19-21.

The material is stored in the collections of the $\mathrm{Na}$ tural History Museum of Basel, Switzerland (Augustinergasse 2, CH-4001 Basel) as catalog numbers C39028 to C39348. Thin sections of agglutinated Foraminifera include the numbers C39349 to C39357. The specimen of Planorbulina difformis (RWL 2-29, Plate 10, fig. 10) is kept within the collection of the MSc-Thesis of Laurine Scherler, University of Fribourg (Switzerland).

\section{Ammobaculites? sp. \\ (Plate 1, fig. 15a, b)}

Distribution research area: Late Rupelian, "Marnes à foraminifères", outcrop Eguisheim.

Catalogue-No.: C39200.

Remarks: A small species, supposedly belonging to Ammobaculites. Much smaller and flatter than the simultaneously occuring Ammobaculites agglutinans (Plate 1, figs. 13, 14). Due to the small size thin sections could not be prepared.

\section{Bolivina beyrichi Reuss, 1851 \\ (Plate 7, figs. 3a, b, 4a, b)}

* 1851 Bolivina Beyrichi-Reuss: 83; pl. 6, fig. 51.

1875 Bolivina Beyrichi Reuss var. carinata - HANTKEN: pl. 7 , fig. 12 .

1884 Bolivina Beyrichi Rss. - ANdreaE: ?; pl. 8, figs. 4-8.

1958 Bolivina beyrichi Reuss - BATJEs: 131; pl. 5, fig. 11a, b.

1962 Bolivina beyrichi beyrichi ReUss, 1851 (cf. beyrichi bituminosa SPANDEL 1909) - Doebl: 389; pl.57, fig. 5a, b.

1965 Bolivina (Brizalina) beyrichi (REUss) - GRAMANN: fig. $1 / 7$.

1967 Bolivina beyrichi beyrichi Reuss, 1851 - Hofmann: 137-141; pl. 3, figs. 1, 2a, b, 3a, b, 4a, b.

1967 Bolivina beyrichi carinata HANTKEN, 1875 - HoFMANN: 142-141; pl. 3, figs. 5a, b, 6a, b.

1987 Bolivina beyrichi beyrichi Reuss - ReISER: 85; pl. 8, figs. 6, 11. 
1987 Bolivina beyrichi carinata HANTKen - ReISER: 85; pl. 8, figs. 8, 13 .

1994 Bolivina beyrichi Reuss, 1851 - GRIMm: 78-79; pl. 1, fig. 6.

1994 Brizalina beyrichi Reuss - Huber: 74-75; pl.5, figs. 6-9.

1998 Bolivina beyrichi beyrichi Reuss - CICHA et al.: 83; pl. 44, figs. 1-2.

1998 Bolivina beyrichi carinata HANT Ken - Cicha et al.: 83; pl. 44, fig. 3 .

2000 Bolivina beyrichi Reuss, 1851 - MehrnusCH: 223233; pl. 1, figs. 1-8, pl. 2, figs. 1-8.

2002 Bolivina beyrichi-Grimm: 74, pl. 1, fig. 8.

Type locality and horizon: Hermsdorf near Berlin or Freienwalde on the Oder (Germany), "Septharienton", "Eocene" (sensu Reuss 1851).

Holotype: depository not given

Distribution research area: Late Rupelian, "Marnes à foraminiferes", "Schistes à poisons", "Couches à Mélettes”, drillings Allschwil-2 and DP-202, outcrops Eguisheim and Rheinweiler.

Catalogue-No.: C39170 (Plate 7, fig. 4), C39171 (Plate 7, fig. 3).

Remarks: According to Mehrnusch (2000) the previous reports of various subspecies of Bolivina beyrichi (ssp. carinata HANTKEN, 1875; bituminosa SPANDEL, 1909; beyrichi) represent ecomorphotypes, with no indication of regional speciation. Thus he revokes HoFmANN's (1967) concept of two morphometric and morphologic clearly separable subspecies (ssp. beyrichi, carinata). Accordingly the carinate, spinose and "normal" morphotypes of the research area are exclusively attributed to Bolivina beyrichi.

Bolivina crenulata Cushman, 1936

(Plate 7, figs. 5, 6a, b)

* 1936 Bolivina crenulata-Cushman: 50; pl. 7, fig. 13.

1967 Bolivina crenulata crenulata CusHMAN 1936 - HofMANN: 146-147; pl. 1, figs. 4a, b, 5a, b, 6a, b.

1974 Bolivina crenulata trunensis HofMANN 1967 - DoebL \& Sonne: 28; pl. 7, fig. 52.

1987 Bolivina crenulata Cushman - ReISer: 86; pl.8, figs. 17, 21.

1998 Bolivina crenulata CUshmAN - Cicha et al.: 83; pl. 43, figs. 11, 12.

Type locality and horizon: near Budapest (Hungary), "Kleinzellner Tegel”, "Upper Eocene” (sensu Cushman 1936).

Holotype: Cushman Laboratory, Sharon, Massachusetts, USA, No. 21497.

Distribution research area: possibly Early Rupelian, "Zone fossilifère" and Late Rupelian, "Marnes à Cyrènes" and Niederrödern Formation, drilling Allschwil-2.
Catalogue-No.: C39338 (Plate 7, fig. 5), C39335 (Plate 7, fig. 6), C39224 (Plate 7, fig. 7).

Remarks: A few badly preserved specimens from the Earliest Rupelian "Zone fossilifere" are tentatively associated with this species (see Plate 7, fig. 7). They show a resembling pitted surface morphology and are of similar size as Bolivina crenulata from the "Marnes à Cyrènes". The latter material deviates somewhat from the type descrition in having more obscured chamber outlines.

\section{Bolivina melettica Andreae, 1884 \\ (Plate 7, fig. 9a, b)}

* 1884 Bolivina melettica n. sp. - AndreaE: 165; pl. 11, fig. 5. 1958 Bolivina beyrichi Reuss var. melettica ANDREAE BATJES: 131; pl. 5, fig. 10a, b.

1967 Bolivina melettica AndreaE - Hofmann: 177; pl. 1, fig. 3a, b.

1994 Bolivina melettica (ANDreAe) - Huber: 73-74; pl. 5, figs. 1-4.

Type locality and horizon: Buchsweiler (Bouxwiller, Alsace, France), "Fischschiefer", "Middle Oligocene" (sensu ANDREAE 1884).

Holotype: Depository not given.

Distribution research area: Late Rupelian, “Couches à Mélettes”, drilling Allschwil-2, "Schistes à poissons", outcrop Rheinweiler

Catalogue-No.: C39154.

Remarks: This species is very similar to Bolivina beyrichi (REUss 1851), but lacks the marginal spines or carinae, features more inclined chambers and shows less distinct chamber outlines. The species is not restricted to the "Schistes à poissons" beds, as reported by Huber (1994) and proposed by ANDrEAE (1884).

Chiloguembelina cubensis (PALMER 1934)

(Plate 15, figs. 7a, b, 8)

? 1884 Textilaria gracillima n.sp. - AndreaE: 143; pl. 8, fig. 9.

* 1934 Guembelina cubensis - PALmer: 74, figs. 1-6.

? 1940 Guembelina ototara - FINLAY: 453; pl. 63, figs. 50-52.

1958 Gümbelina gracillima (ANDREAE) - BATJES: 163; pl. 11, figs. 9a, b.

1974 Chiloguembelina cubensis (PALMer, 1934) - Doebl \& SONNE: 33; pl. 9, fig. 70a, b.

1985 Chiloguembelina cubensis (PALMer) - Jenkins: 274; fig. 6.13a, b.

1987 Chiloguembelina cubensis (PALMER) - REISER: 115116; pl. 18, figs. 12, 13 .

1991 Chiloguembelina cubensis PALMer - Spezzaferri \& Premoli Silva: 250, pl. 10, figs. 5a, 6a, 7a, 8a, 9a, b. 
? 1994 Streptochilus gracillima(AndreAE) - HubER: 72; pl. 7 , figs. $3,4$.

1994 Chiloguembelina cubensis (PALMER) 1934 - SPEZzAFERRI: 65; pl. 29, fig. 1.

1998 Chiloguembelina cubensis (PAlmer) - Cicha et al.: 89-90; pl. 30, figs. 1, 2.

? 1998 Chiloguembelinagracillima (ANDREAE, 1884)-CICHA et al.: 90; pl. 30, figs. 3, 4.

2003 Chiloguembelina cubensis - Premoli Silva et al.: pl. 12 , fig. 6.

2006 Chiloguembelina cubensis (PALMer 1934) - Huber et al.: 473-474; pl. 16.3, figs. 23, 24.

Type locality and horizon: Palmer Station 1163, Cartagena, St. Clara Province (Cuba), "Lower Oligocene” (sensu PALMER 1934). Cuba.

Topotypes: Museo Poey, Universidad de La Habana,

Distribution research area: Late Rupelian, "Marnes à foraminiferes" to Niederrödern Formation, drilling Allschwil-2, "Marnes à foraminiferes", drilling DP-202, outcrop Eguisheim.

Catalogue-No.: C39201 (Plate 15, fig. 7), C39038 (Plate 15, fig. 8).

Remarks: According to the short description ("globulose chambers with smooth, finely perforated and glossy wall"), the single figure and the given size (1 $=250 \mu \mathrm{m})$ of Textilaria gracillima by ANDREAE (1884) the latter species possibly represents the first report of Chiloguembelina cubensis. Consequently the species was listed by Batjes (1958) and Huber (1994) as Gümbelina or Streptochilus gracillima. Сıсна et al. (1998) define Chiloguembelina cubensis as striate and C. gracillima as pustulate, closely related taxa. Huber et al. (2006) characterize Chiloguembelina cubensis as striate and more elongated compared to the pustulate and more tapered $C$. ototara. The material from the research area however yields striate, semistriate, pustulo-striate and pustulate specimens.

As the original description and type figure of Textilaria gracillima lacks important information (see also Huber 1994; e.g., presence of striation), a reevaluation of the taxonomical status Chiloguembelina cubensis, C. gracillima and C. ototara should be considered. However the type material seems to be lost (oral communication, University of Strasbourg) and the type locality and section can not be precisely located.

\section{Cibicidoides roemeri (REuss 1856) \\ (Plate 9, fig. 11a-c)}

1856 Rotalia roemeri-Reuss: 240; pl. 4, fig. 52a-c.
1958 Cibicides lobatulus (WAlker \& JACOB) - BATJEs: 153-154; pl. 9, fig. 7a-c.

non 1994 Heterolepa römeri (TEN DAM \& ReINHOLD) Huber: 84; pl. 12, figs. 1-3.

Type locality and horizon: "Casseler Schichten, Sand", Kassel (Germany), "Oligocene” (sensu Reuss 1856).

Holotype: Depository not given.

Distribution research area: Late Rupelian, “Marnes à foraminifères", drilling DP-202, drilling Allschwil-2.

Catalogue-No.: C39307.

Remarks: Some of the specimens from the research area reach sizes twice as large as those reported for the type material. This species represents generally the largest taxon within the genus Cibicidoides of the research area.

\section{Cycloforina gracilis (KARRER 1867)}

(Plate 4, fig. 4a-c)

* 1867 Quinqueloculina gracilis - KARRER: 361; pl.3, fig. $2 \mathrm{a}-\mathrm{c}$.

1974 Cycloforina gracilis (KARRER 1867) - LUCZKOWSKA: 79-80; pl. 12, fig. 1a-c.

1998 Cycloforina gracilis (KARRER) - RöGL: 142; pl.3, figs. 5, 6 .

Type locality and horizon: Holubica, near Pieniaky, Galicia (Poland), "Neogen" (sensu Karrer 1867).

Holotype: Depository not given.

Distribution research area: Late Rupelian, “Couches à Mélettes", "Marnes à Cyrènes", drilling DP-202, drilling Allschwil-2.

Catalogue-No.: C39342.

Remarks: The material from the research area is considerably smaller than the minimal size of $500 \mu \mathrm{m}$ given by LUCZKOWSKA (1974) and the size of 1.6 mm given by KARRER (1967).

\section{Globotruncana linneiana (D'ORBIGNy 1839)}

(Plate 12, fig. 5a-c)

* 1839 Rosalina linneiana - D'Orbigny: 101; pl. 15, figs. 10-12.

1985 Globotruncana linneiana (D'ORBIGNY) - CARON: 50; figs. 20.5a-c, 20.6a-c.

2004 Globotruncana linneiana (D'ORBIGNY 1839) Premoli Silva \& Verga: 109, pl. 39, figs. 2a-c, 3a-c, $4 a-c$.

Type locality and horizon: "marine sands" (Cuba), "recent" (sensu D'ORBIGNY 1839).

Holotype: Depository not given.

Distribution research area: Late Rupelian, “Marnes à Cyrènes”, drilling DP-202. 


\section{Catalogue-No.: C39063.}

Remarks: As the chambers of the specimens from the research area show a slightly steeper inclination than normal, they may belong to the subspecies $G$. linneiana obliqua Herm, 1965 described from the Early Maastrichtian of northern Spain.

\section{Karreriella chilostoma (REuss 1852)}

(Plate 3, figs. 4a-c, 5a-c)

* 1852 Textularia chilostoma-REUss: 18, figs. a, b.

1884 Gaudryina chilostoma Rss. var. globulifera Rss. ANDREAE: ?; pl. 7, figs. 8a, b, 9.

1958 Karreriella siphonella (REUss) var. chilostoma (REUSs) - BATJEs: 101; pl. 1, fig. 8a, b.

1962 Gaudryina chilostoma chilostoma ReUss 1852 - DoeBL: 387; pl. 56, fig. 9a, b.

1994 Karreriella chilostoma (REUss 1852) - GRIMm: 66-67; pl. 2, fig. 1.

1994 Siphotextularia chilostoma (Reuss) - Huber: 66; pl. 2, figs. 7,8 .

2002 Karreriella chilostoma-GRIMM: 74, pl. 1, fig. 4.

Type locality and horizon: "Septarienthone", Görzig near Köthen (Germany, sensu Reuss 1856).

Holotype: Depository not given.

Distribution research area: Late Rupelian, "Marnes à foraminiferes", drilling DP-202, drilling Allschwil-2, "Marnes à Cyrènes", drilling DP-202.

Catalogue-No.: C39244 (Plate 3, fig. 4), C39314 (Plate 3, fig. 5).

Remarks: The test of the single specimen (see Plate 3, fig. 4a-c) derived from the "Couches à Melettes" is entirely agglutinated of coccoliths, suggesting a habitat lacking sufficient clastica or oversupply of nannoplankton material (blooms). The type description does not recognise the trochospiral nature of the test.

\section{Lenticulina aff. reniformis (D'ORBIGNY 1846) \\ (Plate 5, fig. 14a-d)}

Distribution research area: Late Rupelian, "Marnes à foraminifères", drilling Allschwil-2, "Marnes à Cyrènes" drilling DP-202, outcrop Retzwiller.

Catalogue-No.: C39283.

Remarks: The rare specimens from the "Marnes à foraminiferes" display a keel similar to the type material. In the more abundant specimens derived from the "Couches à Mélettes" a rounded periphery is developed. The speciemns are collectively linked to Lenticulina reniformis, but may represent two different taxa.

\section{Pararotalia canui (Cushman 1928)}

(Plate 11, fig. 9a-c)

* 1856 Rotalia stellata - Reuss: 242; pl. 5, fig. 54.

1928 Rotalia canui nom. nov. - CUSHMAN: 55; pl. 3, fig. 2.

1987 Pararotalia canui (Cushman) - ReIser: 105-106; pl. 14, figs. 1-3.

Type locality and horizon: "Casseler Schichten, Sand", Luithorst (Germany), "Oligocene” (sensu Reuss 1856).

Holotype: Depository not given.

Distribution research area: Late Rupelian, "Marnes à Cyrènes", drilling DP-202, drilling Allschwil-2.

Catalogue-No.: C39072.

Remarks: As Ehrenberg (1838) already used the term Rotalia stellata, therefore, it was renamed by Cushman (1928). The figures of the latter author however show more inflated chambers and an arched lateral shape compared to the very schematic type figures given by Reuss (1856). Pararotalia canui rhenana (ELlermann 1960; see Plate 11, fig. 7a-c) from the Late Oligocene of the Lower Rhine Embayment lacks the umbilical disc as described by Reuss (1856) and shows a more pinched, less inflated and more straight lateral view than the Pararotalia canui reported by Cushman (1928). The varying material from the research area falls in between both descriptions (Pararotalia cf. P. canui; see Plate 11, fig. 8a-c), as some specimens bear the umbilical disc, while others lack it.

Several other very similar species (e.g., Pararotalia curryi Loeblich \& TAPPAN) may belong to P. canui.

\section{Reticulophragmium acutidorsatum (HANTKEN 1868)}

(Plate 2, figs. 4a, b, 5)

* 1868 Haplophragmium acutidorsatum-HANTKEN: 82; pl. 1, fig. 1.

1884 Haplophragmium acutidorsatum Hant. - Andreae: ?; pl. 7, fig. 5.

1994 Reticulophragmium acutidorsatum (v. HANTKEN) Huber: 63; pl. 1, figs. 9, 11, 12.

1998 Reticulophragmium acutidorsatum (HANTKEN) Cicha et al.: 123, fig. 60; pl. 4, figs. 12-14.

2005 Reticulophragmium acutidorsatum (HANTKEN 1868) - Kaminski \& Gradstein: 488-491, figs. 122-1, 122-2; pl. 122, figs. 1a-7c.

Type locality and horizon: "Kis-Czell Mergel”, multiple possible type localities (Hungary), "Oligocene" (sensu Hant Ken 1868).

Holotype: Depository not given.

Distribution research area: Late Rupelian, "Marnes à foraminiferes", drilling DP-202, drilling Allschwil-2, outcrop Eguisheim. 
Catalogue-No.: C39330 (Plate 2, fig. 4), C39351 (Plate 2, fig. 5, thin section).

Remarks: Due to the presence of supplementary apertures and sigmoidal sutures in Cyclammina placenta the latter species is separated from $R$. acutidorsatum by KAMINSKI \& GRADSTEIN, 2005 (in contrast to other authors). The material from the research area shows less distinctly developed characteristics (probably a preservation issue) and is therefore preliminarily associated with $R$. acutidorsatum. The type figure of HANTKEN (1868) shows a more pinched ("keeled") chamber cross section.

\section{Reticulophragmium? acutidorsatum exigua (SCHRODT 1893) \\ (Plate 2, fig. 6a, b)}

* 1893 Cyclammina acutidorsata (HANTKEN) var. exigua SCHROdT: 735.

1962 Cyclammina placenta exigua Schrodt 1893 - Doebl: 389; pl. 57, fig. 4.

Type locality and horizon: "Septarienthon", drilling in Frankfurt am Main (Germany), "Oligocene" (sensu ScHrodT 1893).

Holotype: Depository not given.

Distribution research area: Late Rupelian, "Marnes à foraminifères", "Schistes à poisons", drilling DP-202.

\section{Catalogue-No.: C39278.}

Remarks: Due to the very thin test with supposedly compressed chambers, no thin sections of this species could be successfully produced. Thus the generic status remains uncertain. The size is considerably smaller than in the nominate species.

\section{Sabellovoluta bumboldti (REUss 1851) \\ (Plate 2, figs. 1a, b, 2a-c, 3)}

* 1851 Spirolina Humboldti-Reuss: 65; pl. 3, figs. 17, 18.

? 1994 Ammobaculites agglutinans (D'Orbigny 1846) Grimm: 62, 63; pl. 2, fig. 6.

1994 Sabellovoluta humboldti (Reuss) - Huber: 63; pl. 1, figs. 7, 8.

1998 Sabellovoluta humboldti (REUss) - CicHA et al.: 124, 125; pl. 4, figs. 7, 9.

Type locality and horizon: "Septarienthon", Hermsdorf near Berlin (Germany), "Eocene” (sensu Reuss 1851).

Holotype: Depository not given.

Distribution research area: Late Rupelian, "Marnes à foraminiferes", drilling DP-202, drilling Allschwil-2.

Catalogue-No.: C39323 (Plate 2, fig. 1), C39300 (Plate 2, fig. 2), C39350 (Plate 2, fig. 3, thin section).
Remarks: Some specimens show the development of a trigonal shape in the last few chambers, a feature reported by ANDREAE (1890) of "Haplophragmium" humboldti var. trigona.

Sphaeroidina variabilis REUSS, 1851

(Plate 9, figs. 5a, b, 6a, b)

* 1851 Sphaeroidina variabilis - Reuss: 88; pl. 7, figs. 61a-c, 62, 63a, b, 64a, b.

1958 Sphaeroidina bulloides D'ORBIGNY - BATJEs: 140; pl. 6, fig. 11a, b.

1994 Sphaeroidina variabilis Reuss, 1851 - GRIMm: 80, 81; pl. 3, fig. 7.

1994 Sphaeroidina cf. bulloides D'Orbigny - Huber: 77; pl. 7, fig. 75-7.

Type locality and horizon: "Septarienthon", Hermsdorf or Freienwalde near Berlin (Germany), "Eocene" (sensu Reuss 1851).

Holotype: Depository not given.

Distribution research area: Late Rupelian, "Marnes à foraminiferes", drilling DP-202, drilling Allschwil-2, outcrop Eguisheim.

Catalogue-No.: C39318 (Plate 9, fig. 5), C39316 (Plate 9, fig. 6).

Remarks: According to GRIMm (1994) the differentiation between the very similar species Sphaeroidina bulloides D'ORBIGNY, 1846 and S. variabilis by means of the deeper suture of the latter is valid and thus negates the merging of both species affected by Batjes (1958).

Spiroplectinella carinata (D'ORBIGNY 1846)

(Plate 2, figs. 9a-c, 10a, b, 11)

* 1846 Textularia carinata - D'Orbigny: 247; pl. 14, figs. 32-34.

1884 Plecanium carinatum D'ORB. sp. - AndreAe: pl.7, fig. 10a, b.

1958 Spiroplectammina carinata (D'ORBIGNY) - BATJEs: 98, 99; pl. 1, fig. 2a, b.

1962 Spiroplectammina carinata carinata (D'ORBIGNY 1826) - DoeBL: 386; pl. 56, figs. 6, 7.

1993 Spiroplectinella carinata (D'ORBIGNy 1846) - GRIMM: 22-24, fig. 1a, b, fig. 3a-h.

1994 Spiroplectinella carinata (D'ORBIGNY 1846) - GRIMm: 64, 65; pl. 1, fig. 5, pl. 2, fig. 8 .

1994 Spiroplectinella carinatus (D'ORBIGNY) - HuBER: 64, 65; pl. 1, figs. 13-17.

1998 Spirorutilus carinatus (D'ORBIGNY) - Cicha et al.: 128; pl. 5, fig. 10.

2002 Spiroplectinella carinata-GRIMm: 74, pl. 1, fig. 3.

2003 Spirorutilus carinatus (D'ORBIGNY) - SzTrÁKos \& DU FORNEL: 259, pl. 3, fig. 5. 
Type locality and horizon: not given, probably "Tegel” clay pit, Nussdorf, Vienna (Austria), "Badenian" (sensu PAPP \& SCHMIDT 1985).

Lectotype: Badenian of Nussdorf, Hauer-D’Orbigny Collection, Geologische Bundesanstalt, Vienna, Austria.

Distribution research area: Late Rupelian, "Marnes à foraminiferes", drilling DP-202, drilling Allschwil-2, outcrop Eguisheim.

Catalogue-No.: C39176(Plate 2, fig. 9), C39177 (Plate 2, fig. 10), C39353 (Plate 2, fig. 11, thin section).

Remarks: According to Grimm (1993), the final position of this species is within the genus Spiroplectinella Kiselman, 1972. The proof of pseudopores in the nominate species ( $S$. wrighti) of Spiroplectinella renders the younger genus Spirorutilus HofKeR, 1973 unnecessary, as the latter was only separated due to the presence of pseudopores (HOTTINGER et al. 1990).

\section{Siphotextularia labiata (REuss 1861)}

(Plate 3, figs. 12a-c, 13, 14)

\section{* 1861 Textilaria labiata-Reuss: 362; Plate 2, fig. 17a-c.}

Type locality and horizon: "Crag, Sand", Antwerpen (Belgium), "Pliocene" (sensu Reuss 1861).

Holotype: Depository not given.

Distribution research area: Late Rupelian, "Marnes à foraminiferes", drilling DP-202, drilling Allschwil-2, outcrop Eguisheim.

Catalogue-No.: C39319 (Plate 3, fig. 12), C39356 (Plate 3, fig. 13, thin section), C39357 (Plate 3 , fig. 14, thin section).

Remarks: Completely preserved specimens show an entirely biserial test and are hence attributed to $\mathrm{Si}$ photextularia due to the flanged aperture. The more triangular elongated shape, the more rectangular chamber shape and the more elongated aperture slit furthermore separate the material from Karreriella siphonella.

\section{Trochammina sp.}

(Plate 2, fig. 13a-c)

Distribution research area: Late Rupelian, "Marnes à foraminiferes", drilling DP-202, outcrop Eguisheim.

Catalogue-No.: C39285.

Remarks: Due to the coarsely agglutinated, nearly discoidal to trochospiral test with four chambers in the last whorl the material from the research area is associated with the genus Trochammina.
Trochammina cf. quadriloba (GRZYBOwsKi 1896)

(Plate 3, fig. 1a, b)

Distribution research area: Late Rupelian, "Marnes à foraminiferes", drilling DP-202.

Catalogue-No.: C39106.

Remarks: The material from the research area resembles a flattened Trochammina quadriloba. In the nominate species the four chambers are spherical.

Uvigerina gracilis germanica CUSHMAN \& EDWARDS, 1938

(Plate 8, figs. 1a, b, 2a, b, 3a, b)

* 1938 Angulogerina germanica - Cushman \& Edwards: 85; pl. 15, figs. 14-16.

1958 Angulogerinagracilis(Reuss) var. germanica Cushman \& Edwards - BATJes: 136; pl. 6, fig. 4.

1987 Trifarina gracilis (Reuss) var. germanica Cushman \& EDWARdS - REISER: 84; pl. 8, fig. 1.

? 1994 Neouvigerina oligocaenica (ANDREAE) - HubER: 76; pl. 6, figs. 7, 8, 10, 11 .

1998 Uvigerina gracilis Reuss - Cicha et al.: 133; pl. 49, fig. 11.

Type locality and horizon: Calbe near Magdeburg (Germany), "Lower Oligocene" (sensu Cushman \& Edwards 1938).

Holotype: Cushman Laboratory, Sharon, Massachusetts, U.S.A., No. 24678.

Distribution research area: Late Rupelian, "Marnes à foraminiferes", drilling DP-202, drilling Allschwil-2, outcrop Eguisheim.

Catalogue-No.: C39218 (Plate 8, fig. 1), C39214 (Plate 8, fig. 2), C39204 (Plate 8, fig. 3).

Remarks: BATJES (1958) regrouped the species "Uvigerina" oligocaenica ANDREAE, 1884, “U." germanica CUSHMAN \& EDWARDS, 1938 and U. tenuistriata Reuss, 1870 to be variants of Angulogerina gracilis (REuss 1851). At least Uvigerina tenuistriata was later re-elevated to species level and reattributed to the genus Uvigerina (e.g. RöGL 1998). The material of the research area represents the variant germanica, but due to only minor differences is not raised to species level.

\section{Uvigerina cf. multistriata Hant Ken, 1871 \\ (Plate 8, figs. 4a, b, 5a, b)}

Distribution research area: Late Rupelian, "Marnes à Cyrènes", drilling Allschwil-2, "Couches à Mélettes", drilling DP-202.

Catalogue-No.: C39271 (Plate 8, fig. 4), C39277 (Plate 8, fig. 5).

Remarks: CiCHA et al. (1998) report the similarity of the lectotype of Uvigerina multistriata with the 
material described by REISER (1987) as U. cichai and judge the latter as being synonymous. The species resembles Uvigerina gracilis germanica CusHMAN \& EDWARDS, 1938, but features a more rounded apertural view, more globular chambers and attains its maximum diameter faster. The trend of a more biserial arrangement of younger chambers described by REISER (1987) is observable. The rare specimens from the research area however feature less numerous striae than the nominate taxon.

\section{Other fossil groups}

\subsection{Calcareous nannoplankton}

The samples W-81 to W-78 (drilling DP-202) are derived from a transitional facies of organic rich, partly laminated marls containing only poorly preserved, reworked Mesozoic nannoplankton. Widespread reworking of Cretaceous and Paleogene nannofossils is reported from other Late Rupelian localities in the Upper Rhine Graben (e.g., Mainz Basin, Grimm et al. 2005). In sample W-77 to W-67 the well-preserved and abundant nannoflora co-occurs with the highly diverse benthic Foraminifera assemblages of the "Marnes à foraminiferes". In sample W-70 a higher ratio of small Reticulofenestra sp. (related to $R$. minuta) suggest a calm, fully marine milieu within a well-stratified water column (CORIC, pers. comm. 2006). In the subsequent sample W-67 a higher abundance of Coccolithus pelagicus hints at cold-water conditions ( 7 to $14^{\circ} \mathrm{C}$ ) and an increased nutrient supply (e.g., Li 2003, Roetzel et al. 2006, Spezzaferri \& Coric 2001).

This trend continues within the lower part of the "Schistes à poissons" (W-65). Unaffected by the drastic decrease of diversity and abundance of benthic Foraminifera within the "Schistes à poissons", the perseverance of a rich nannoflora with a raised percentage of Braarudosphaera bigelowii indicates a higher fluviatile freshwater influx (CORIC, pers. comm. 2006).

In the entire Paratethys a bloom of Reticulofenestra ornata occurs in the lower NP23 nannoplankton zone. Further occurrences of Reticulofenestra ornata are also reported from the zone NP24. The high abundance of Reticulofenestra cf. $R$. ornata in sample W-61 and the absence of Reticulofenestra umbilica and Ericsonia formosa indicate a general age of NP23-24 for the "Marnes à foraminiferes" - "Schistes à poissons" succession of the research area (CORIC, pers. comm. 2006). Reticulofenestra ornata is considered to be endemic to the Paratethys region (e.g., Melinte 2005).

\subsection{Bolboforma}

Bolboforma latdorfensis and Bolboforma irregularis share a globular test shape of about $110 \mu$ to $130 \mu$ in diameter, a short neck with a relatively wide opening and reticulospinose ornamentation. The main difference between the two species is the more structured, hexagonal reticulation of Bolboforma latdorfensis. Due to the difficult classification of the slightly eroded specimens from the research area, the attribution to the two species has a preliminary character. The overlapping ranges of both species indicate a "Middle" Oligocene age (NP24; SPIEgler \& Spezzaferri 2005).

According to Spiegler \& Spezzaferri (2005), Bolboforma are representative for temperate to cool, fully marine conditions and were restricted to middle and higher latitudes. The exclusive occurrence of $\mathrm{Bol}$ boforma in sample A-17 (drilling Allschwil-2) suggests a short pronounced recurrence of fully marine conditions in the upper part of the "Marnes à Cyrènes".

\subsection{Vertebrata}

The record of fish otoliths from the research area is limited. At the drill site Allschwil-2 otoliths are restricted to the middle part of the "Marnes à Cyrènes" and the middle part of the Early Rupelian "Zone fossilifere". Within the "Marnes à Cyrènes" the otoliths suggest a Late Rupelian to Early Chattian age. The deduced fish species indicate freshwater to brackish conditions. This coincides with the predominantly brackish ostracod fauna and the near absence of Foraminifera in this unit. The single specimen of the lagoonal / brackish Enoplophthalmus sp. from the "Zone fossilifere" co-occurs with abundant brackish ostracod species.

At the drill site DP-202 otoliths occur exclusively in the uppermost sample W-1 within the Niederroedern Formation. The occurrence of Palaeolebias symmetricus implies freshwater to brackish conditions and a Late Rupelian to Early Chattian age. In contrast, $\mathrm{Da}$ palis angustus indicates a brackish milieu and a definite Rupelian age.This inmplies either an earlier onset of the Niederroedern Formation in the Late Rupelian at the DP-202 drill site or the conclusion of an extended range of Dapalis angustus. 
Cetorhinus parvus, Aeoliscus heinrichi and scales of Clupea (Meletta) sp. were only found in the "Schistes à poissons" at the DP-202 drill site (sample W-59) and the outcrop Rheinweiler. Occurrences within the subsequent "Couches à Mélettes" are reported by Pharisat (1991a, b).

Related to the recent basking shark Cetorbinus maximus, Cetorhinus parvus represents a large, plankton-feeding shark species that generally prefers cooler water. Aeoliscus heinrichi is interpreted as an "upright" swimming fish of warmer littoral environments in accordance with very similar recent species (PHARISAT 1991a). Cetorhinus parvus and Aeoliscus heinrichi were also found in the "Série grise" sediments of the Allschwil clay pit (Hess \& Weiler 1955). Dasyatus (stingrays) represents a shallow marine genus that tolerates reduced salinities (JosT, pers. comm. 2006).

A partial, but relatively complete skeleton of a diomedeoidid bird (resembling extant storm petrels) was found during a field course in 2004. As stated in De Pietri et al. (2010) the relatively frequent fossil occurrence of these pelagic birds in the Rupelian of the Upper Rhine Graben may be related to high seasonal productivity.

\section{Biostratigraphy}

\subsection{Calcareous nannoplankton, fish otoliths, Charophyta, Ostracoda}

According to BERGER et al. (2005a, b), the calcareous nannoplankton indicates a range from zones NP21-22 in the "Zone Fossilifere" to NP23-24 in the "Marnes à foraminiferes" - "Schistes à poissons" "Couches à Melettes" succession.

Reticulofenestra ornata (calcareous nannoplankton) from the Paratethys occurs in the NP23-24 nannoplankton zone (Text-fig. 3). The high abundance of Reticulofenestra cf. R. ornata in sample W-61 from the drilling DP-202 and the absence of Reticulofenestra umbilica and Ericsonia formosa indicate a similar age for the "Marnes à foraminiferes" - "Schistes à poissons" succession of the research area (CORIC, pers. comm. 2006).

The fish otoliths "genus Eleotridarum" cf. martinii (sample A-13a, Allschwil-2) and Palaeolebias monasterii (A-20a, Allschwil-2) allow the attribution of the Upper "Série grise" to the Late Rupelian (Text-fig. 3; otolith-zone OT-02, REICHENBACHER et al. 1996; Reichenbacher et al. 2002). A single otolith of Palaeolebias symmetricus recorded from the youngest sample (W-1) of the Niederroedern Formation of the drilling DP-202 indicates a Late Rupelian to Earliest Chattian age and thus implies a slightly earlier onset of the fluviatile Niederroedern formation than previously supposed (Text-fig. 3; e.g., otolith zonation in BERGER et al. 2005b, REICHENBACHER 2000, Reichenbacher \& Weidmann 1992). A comparable observation is stated by MöDDEN et al. (2000) for the time-equivalent freshwater beds ("Süßwasserschichten") of the Mainz Basin. Dapalis angustus from the same sample represents the type species for the "Mid"-Rupelian OT-01 otolith zone (see also first description in ReICHENBACHER \& WeIDMANN 1992). More recent discoveries from the Lower Freshwater Molasse (UMM) of the Swiss Jura Mountains (REICHENBACHER et al. 1996) allow a correlation also with younger (Early Chattian) ages.

This coincides with the overlapping occurrence of the algal cysts Bolboforma latdorfensis and Bolboforma irregularis (Rupelian Bolboforma latdorfensis-Zone; Spiegler \& SPezzaferri 2005), giving a "Middle" Oligocene age.

The charophyte assemblages from the "Marnes à Cyrènes" and Niederroedern Formation of the drilling Allschwil-2 and DP-202 suggest a correlation with the NP24 nannoplankton zone (possibly Chara microcera zone; Text-fig. 3).

So far no established biostratigraphy based on Ostracoda exists for Central Europe. A preliminary scheme was compiled by STEININGER et al. (1982), which describes the Rupelian ostracod-zone No 0 as lower part of the Oligocene Hemicyprideis helveticasuperzone of the Central Paratethys. The index species Hemicyprideis helvetica and Cyamocytheridea punctatella of the Ostracod-zone No 0 occur in high numbers in the "Marnes à Cyrènes" of the research area. The record of Hammatocythere ex gr. H. oertlii from the Early Rupelian lower "Zone fossilifere" coincides with the Earliest Rupelian last occurrence date of the this species given by HARDENBOL et al. (1998).

\subsection{Planktonic Foraminifera}

\subsubsection{Reworking and assemblage ranges}

Only four species (Globigerinella obesa [Plate 17, fig. 4], Globorotaloides variabilis [Plate 18, fig. 6], Dentoglobigerina baroemoenensis, Globigerina ciperoensis [Plate 16, fig. 1]) of the recorded planktonic Foraminifera reflect true Oligo-Miocene ranges and are thus definitely not reworked (Text-fig. 13). The re- 
maining species represent either long-ranging taxa (e.g., Globigerina praebulloides [Plate 16, figs. 2, 3], Paragloborotalia nana [Plate 17, fig. 7], Catapsydrax unicavus [Plate 18, fig. 4]), a few Barton-Priabonian to Rupelian taxa (e.g., Subbotina angiporoides [Plate 16, fig. 7]) or some Lutetian to Rupelian taxa (e.g., Subbotina utilisindex [Plate 17, figs. 2, 3], Pseudohastigerina micra [Plate 17, fig. 6]).

The most important species for isolating assemblage ranges are represented by Globigerinella obesa and Globorotaloides variabilis as "first occurrence"marker (both Mid P20 to Miocene), whereas Pseudohastigerina micra (Basal Lutetian to Mid P20, Plate 17, fig. 6), Dentoglobigerina yeguaensis (Late Ypresian to Late P20), Subbotina utilisindex (Late Lutetian to Mid P21a), S. angiporoides (Late Priabonian to Mid P21a) and Chiloguembelina cubensis (Early Bartonian to Final P21a) may be important "last occurrence"marker species (Text-fig. 3). However, according to their Eo-Oligocene ranges, the latter species could theoretically all be derived from Eocene deposits, due to the partly significant rate of reworking observed in Late Rupelian sediments of the research area.

\subsubsection{Possible models of assemblage ranges}

(Text-fig. 11)

No reworking of Eo-Oligocene ranging species presumed (setting A)

According to earliest appearance of the "first occurrence"-marker Globigerinella obesa (Mid P20 to Miocene) in sample A-70 (middle "Marnes à foraminifères") and the "last occurrence"-marker Pseudohastigerina micra (Basal Lutetian to Mid P20) in

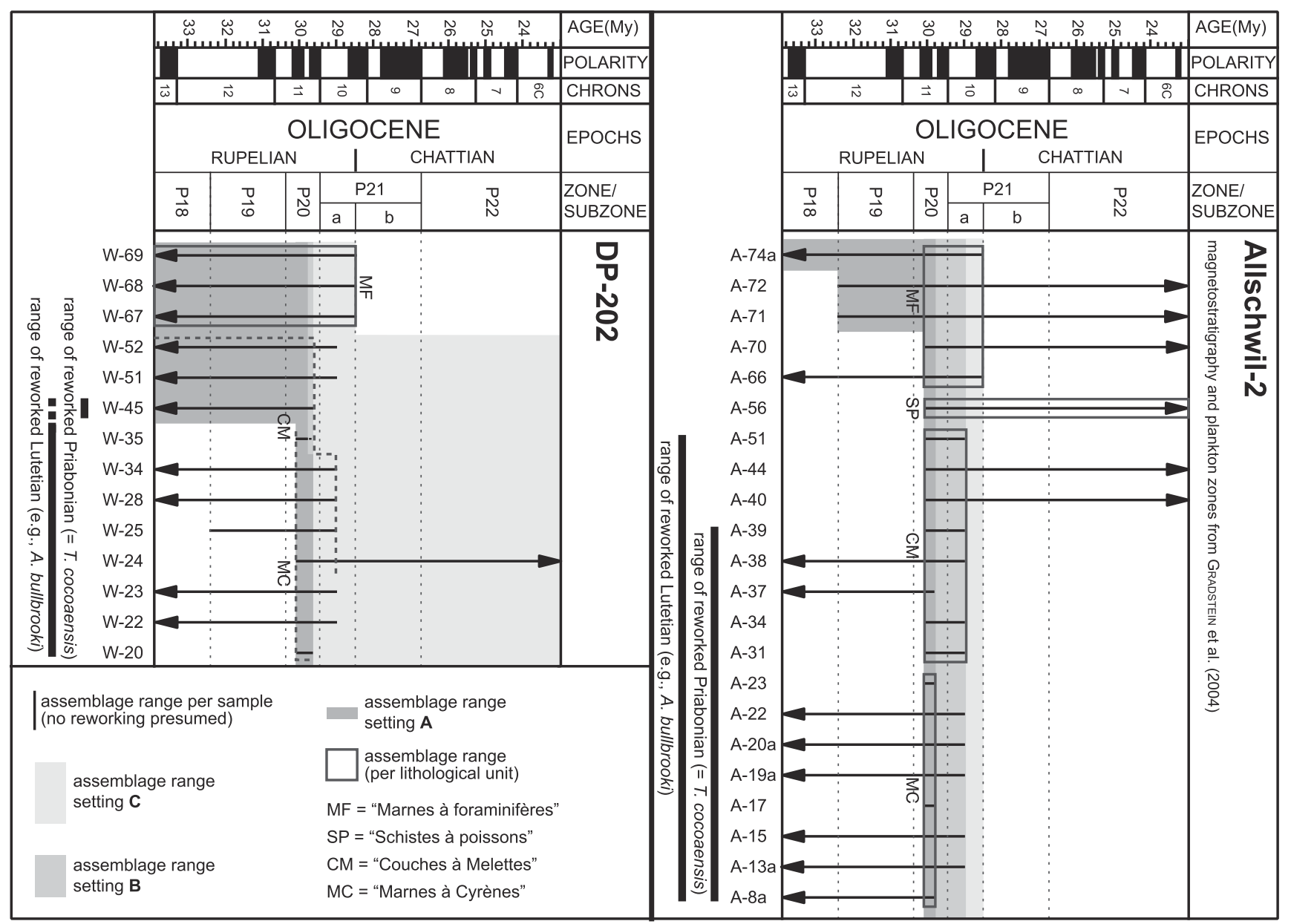

Text-fig. 11: Potential biostratigraphic assemblage range settings of the "Série grise" deposits in relation to facultatively reworked, Eo-Oligocene ranging planktonic Foraminifera species (explanation see text). 
sample A-8a (upper "Marnes à Cyrènes"), the whole "Série grise" ("Marnes à foraminiferes" to "Marnes à Cyrènes") of the drilling Allschwil-2 can attributed to a Mid P20 age. Only the lower part of the "Marnes à foraminiferes" could be older than Mid P20.

At the drilling DP-202 the situation is more complex. Only sample W-35 (upper "Couches à Melettes") represents the Mid P20 age as depicted above. Thus the older samples W-69 to W-45 ("Marnes à foraminifères" to middle "Couches à Melettes") cannot be younger than Mid P20, but older ages are possible because of presence of Chiloguembelina cubensis (Early Bartonian to Final P21a) or Subbotina utilisindex (Late Lutetian to Mid P21a) and S. angiporoides (Late Priabonian to Mid P21a). The youngest evaluable sample W-20 (upper "Marnes à Cyrènes") gives an age of Mid to Late P20 due to the cooccurrence of Dentoglobigerina yeguaensis (Late Ypresian to Late P20) and Globorotaloides variabilis (both Mid P20 to Miocene).

Reworking of Pseudohastigerina spp. presumed (setting B)

Lacking Pseudohastigerina spp., the range is now defined by Globigerinella obesa (Mid P20 to Miocene) in sample A-70 (middle "Marnes à foraminiferes") and Subbotina utilisindex (Late Lutetian to Mid P21a) and $S$. angiporoides (Late Priabonian to Mid P21a). In most of the remaining samples of the drilling Allschwil-2 a Mid P20 to Mid P21a range with a similar lithostratigraphic coverage as in setting $\mathrm{A}$ can be inferred, with possible older ages only in samples A-74a to A-70.

At the drilling DP-202 the slight extension of the range to a Mid P20 to Late P20 age is based on Globigerinella obesa (Mid P20 to Miocene) and Dentoglobigerina yeguaensis (Late Ypresian to Late P20) in sample W-35, with possible older ages in the segment W-69 to W-45.

Reworking of Pseudohastigerina spp. and Subbotina spp. presumed (setting $\mathbf{C}$ )

Based on the same "first occurrence"-markers as above and Chiloguembelina cubensis (Early Bartonian to Final P21a) as "last occurrence"-marker, the corresponding ranges of the relevant lithological units of the two drill cores extend to a Mid P20 to Final P21a age at Allschwil-2.

At DP-202 the samples W-69 to W-67 contain Chiloguembelina cubensis which defines a Final P21a age or older, W-52 to W-45 yield no marker and W-35 to W-20 are not older than Mid P20 due to the occurrence of Globigerinella obesa and Globorotaloides variabilis.

\section{All Eo-Oligocene ranging species reworked (D)}

The samples A-72 to A-71 would not be older than Basal P19, A-70 through A-8a not older than Mid P20. The samples from the drilling site DP-202 W-35 through W-20 would not be older than Mid P20.

\subsubsection{Evaluation of the most likely range linked to reworking phases}

According to the results in chapter 5.2, four reworking events took place at the Allschwil-2 drill site: the lower and middle "Couches à Melettes", the middle to upper "Marnes à Cyrènes" as well as the Niederroedern Formation. These events are important for the biostratigraphic interpretation of the assemblages. Most of the material indicates a reworking of Lutetian deposits, as Lutetian ages are present in all of the above-mentioned reworking events. Priabonian, Ypresian and Cretaceous sediments are of lesser importance. An increase of material of Priabonian age is observed throughout the "Marnes à Cyrènes" event.

Setting A represents the very short Mid P20 range based on the presence of Pseudohastigerina micra as "last occurrence"-marker. The latter species occurs in low abundance only in five samples (see range charts). Of these, only one sample contains no reworked Eocene material.

Setting B presumes Pseudohastigerina micra to be reworked along with the Eocene material. The upper boundary of setting B's Mid P20 to Mid P21 a range is now defined by the relatively abundant and well-represented species Subbotina utilisindex and S. angiporoides. Of 14 corresponding samples, six samples contain no reworked Lutetian or Priabonian material.

Even if the Late Lutetian to Mid P21a ranging Subbotina utilisindex should be reworked, the Late Priabonian to Mid P21a ranging Subbotina angiporoides is generally not recorded in samples containing Turborotalia cocoaensis (marker of reworked Priabonian deposits). Turborotalia cocoaensis thus functions as last occurrence marker. Samples containing one or both species of Subbotina are however always linked to the reworking intervals.

In setting $\mathbf{C}$ the upper boundary of the Mid P20 to Final P21a range is defined by Chiloguembelina cubensis throughout the "Série grise". Chiloguembelina 
cubensis represents the only "last occurrence"-marker derived from the "Marnes à foraminiferes". This lithological unit is not affected by reworked material at the drill sites Allschwil-2 and DP-202. In subsequent lithological units Chiloguembelina cubensis occurrences are always linked to samples within the three reworking events.

If no reworking of Eo-Oligocene ranging species is presumed, the maximum range possible within each lithological unit (dark grey rectangles; Text-fig. 11) gets progressively shorter and older for each younger unit.

The situation at the DP-202 drill site tends to be quite similar, though the reworking events are slightly offset and start higher up in the lithostratigraphic column than at Allschwil-2.

\subsubsection{Conclusions}

Due to the absence of an Oligocene-only "last occurrence"-marker only limited definite conclusions can be drawn:

1. The upper "Marnes à foraminiferes" (sample A-70 to A-66) at Allschwil-2 are confined to a Mid P20 to Final P21a age (last occurrence of Chiloguembelina cubensis, first occurrence of Globigerinella obesa). The remaining younger lithological units of the "Série grise" are not older than Mid P20 (first occurrence dates of Globigerinella obesa and Globorotaloides variabilis).

2. The "Marnes à foraminiferes" at DP-202 are not younger than Final P21a (Chiloguembelina cubensis last occurrence). The lower part of the "Couches à Melettes" cannot be definitively assigned. The upper "Couches à Melettes" and the "Marnes à Cyrènes" can be attributed to an age not older than Mid P20 (same two species as Allschwil-2).

The exclusive association of Subbotina spp. within the range of the reworking events of the "Série grise" suggest an allochthonous source of these taxa.

The state of preservation of the rare Pseudohastigerina micra is generally poor and its occurrence is almost always linked to reworking events. Therefore, the age of the "Série grise" at Allschwil-2 is most likely to be placed within the "Chiloguembelina cubensis - Globigerinella obesa / Globorotaloides variabilis"-assemblage range of Mid P20 to Final P21a (light grey area of setting C; Text-fig. 11). Additionally the "last occurrence"-date of Pseudohastigerina spp. remains somewhat uncertain, as either all species disappear at the P18/P19 boundary (e.g., GRADSTEIN et al. 2004, HARDENBOL et al. 1998) or P. micra continues until a Mid P20 age (Spezzaferri \& Premoli Silva 1991).

At the drill site DP-202 the parameters are even less precise. However, an attribution of the "Série grise" to a similar age range seems plausible, due to the basin-wide, supposedly isochronous onset of the sedimentation ("Marnes à foraminiferes") at the base of the second Rupelian transgression into the Upper Rhine Graben.

Based on a Mid P20 age, the initial flooding of the Upper Rhine Graben does not exactly coincide with the maximum flooding of the global Ru2 sequence, but may rather correspond to the late highstand.

\section{Reworking of Cretaceous and Paleogene Foraminifera}

\subsection{Earlier reports}

\subsubsection{Upper Rhine Graben and adjacent northern and eastern areas}

FISCHER (1965a) published the single comprehensive survey on reworked microfaunas (mainly planktonic Foraminifera) in Rupelian and earliest Chattian sediments from the southern Upper Rhine Graben in his thesis on the regional geology of the area southeast to the city of Basel (Text-fig. 12). Additional outcrops include the clay pits of Allschwil (see also Fischer 1965b) and Therwil (south of Basel; see also BitTerli-Brunner \& Fischer 1988) as well as the Froidefontaine clay pit (southeast of Belfort, E France). As reported by FISCHER (1965a), a strong increase in abundance and diversity can be observed towards the top of the "Série grise", i.e. the regressive phase of the second Rupelian transgression. According to FisCHER (1965a) the occurrence of reworked microfaunas is limited to the upper part of the "Couches à Melettes" ("Septarienton") and the lower part of the "Marnes à Cyrènes" ("Cyrenenmergel").

FisCHER (1965a) compiled an overview of the Oligocene Foraminifera assemblages for the following adjacent sedimentary basins based on the data from numerous publications. 
Oligocene sands from the Lower Rhine Embayment (Ruhr area, W Germany) yield abundant Jurassic to Paleogene benthonic and planktonic Foraminifera (e.g., "Globotruncanids"). Late Oligocene sediments from the Hessian Depression (C Germany) bear Late Cretaceous debris including microfaunal components and reworked Paleogene planktonic Foraminifera (e.g. Heterohelix, "Globotruncanids").

Abundant reworked Cretaceous and Paleogene planktonic Foraminifera occur in Rupelian beds of the Mainz Basin that are equivalent to the upper "Couches à Melettes" and the "Marnes à Cyrènes" of the research area. This coincides with the very abundant and diverse reworked Cretaceous and Paleogene planktonic Foraminifera assemblages from the Late Rupelian "Oberer Rupelton" and "Schleichsand" (= "Série grise") of the Mainz Basin (W Germany; Textfig. 12) reported by SCHÄFER \& KuHN (2004). Accordingly, autochthonous species are often outnumbered by the well preserved reworked material. SCHÄFER \& KuHN (2004) correlate the onset of the reworking with the first sedimentation of more psammite-dominated sediments at the base of the Stadecken Formation (= upper "Couches à Melettes"). Additional Rupelian localities from the Mainz Basin evidencing episodes of reworked Cretaceous and Paleogene material include the Junk clay pit (W Mainz Basin; GrImm et al.2005) and the drilling Lautersheim-1 (S Mainz Basin; SCHÄFER 2000).

FisCHER (1965a) also reports Cretaceous planktonic Foraminifera from two drill cores of Late Rupelian "Série grise" deposits from the central Upper Rhine Graben (Karlsruhe area, SW Germany).

Hasemann \& Heinemann (1957) describe Cretaceous (abundant large "Globotruncana sp.") and possibly Eocene ("Globorotalia sp.") faunal elements from an outcrop of supposedly Late Rupelian age ("Couches à Melettes") from the eastern slope of the Kaiserstuhl volcano.

OHMERT (1993) described one single, supposedly autochthonous benthonic and planktonic Foraminifera assemblage of early P17 age (e.g., Turborotalia cocoaensis [Plate 14, fig. 5]). The assemblage is described from the Late Eocene basal "Couche rouge" bed ("Rote Leitschicht") of the drilling Bremgarten-1 (near Bad Krozingen, Baden, SW Germany).

\subsubsection{Jura Molasse (NW Switzerland)}

Fischer (1965a) describes Cretaceous elements in coarse Oligocene clastica from several locations of the Jura Molasse. Recent samples have been provided by the Section de Paléontologie (Transjurane project, Canton du Jura). They were obtained from Rupelian and ?Chattian sediments ("Septarienton", "Molasse alsacienne") of the Porrentruy and Delémont area and yield Cretaceous and Paleogene reworked Foraminifera (including Nummulites).

\subsubsection{Molasse Basin and northern Alpine margin}

Weidmann, Homewood \& Fasel (1982) described poorly preserved Cretaceous, Paleocene and Eocene planktonic Foraminifera in the marine Rupelian Cucloz Formation from the western flank of the Romond Prealps (W Switzerland) by.

One section in the lower part of of the open marine Late Rupelian (P20) Val d'Illiez Formation (W Chablais Prealps, Haute-Savoie, E France) bears poorly preserved Late Cretaceous and Late Paleocene to Middle Eocene material (UJETZ, KIndLER \& WERNLI 1994).

Abundant Late Cretaceous (e.g., Globotruncana linneiana [Plate 12, fig. 5]) and Middle to Late Eocene (e.g., Morozovella lehneri [Plate 14, Fig. 8], Turborotalia cocoaensis [Plate 14, fig. 5]) planktonic Foraminifera are recorded from the Oligocene, supposedly Rupelian, Flysch deposits of the deeper marine Gersterngraben Formation in the Canton of Bern, W Switzerland (SCHERER 1966).

FisCHER (1965a) describes reworked Cretaceous and Paleogene planktonic Foraminifera from mainly younger Chattian and / or Miocene (partly subalpine) Molasse units. These are found in Yverdon, Bulle and Fribourg (W Switzerland), Wynau (NC Switzerland), the Beichlen-Honegg area (Prealps, canton Lucerne, C Switzerland) and along the Bavarian Alpine margin (S Germany) (Text-fig. 12). Reworked Cretaceous species (including the genera Globotruncana, Globigerinelloides, Heterohelix) from Eggenburgian localities are confirmed by WENGER (1987). A single Rupelian (lower Marine Molasse, "UMM") outcrop yielding Cretaceous and Paleogene material reported by FisCHER (1965a) is located near Bregenz (Vorarlberg, W Austria). No reworking is indicated by ReISER (1987) in his monographic publication on the Rupelian Foraminifera assemblages from southern Bavaria. 


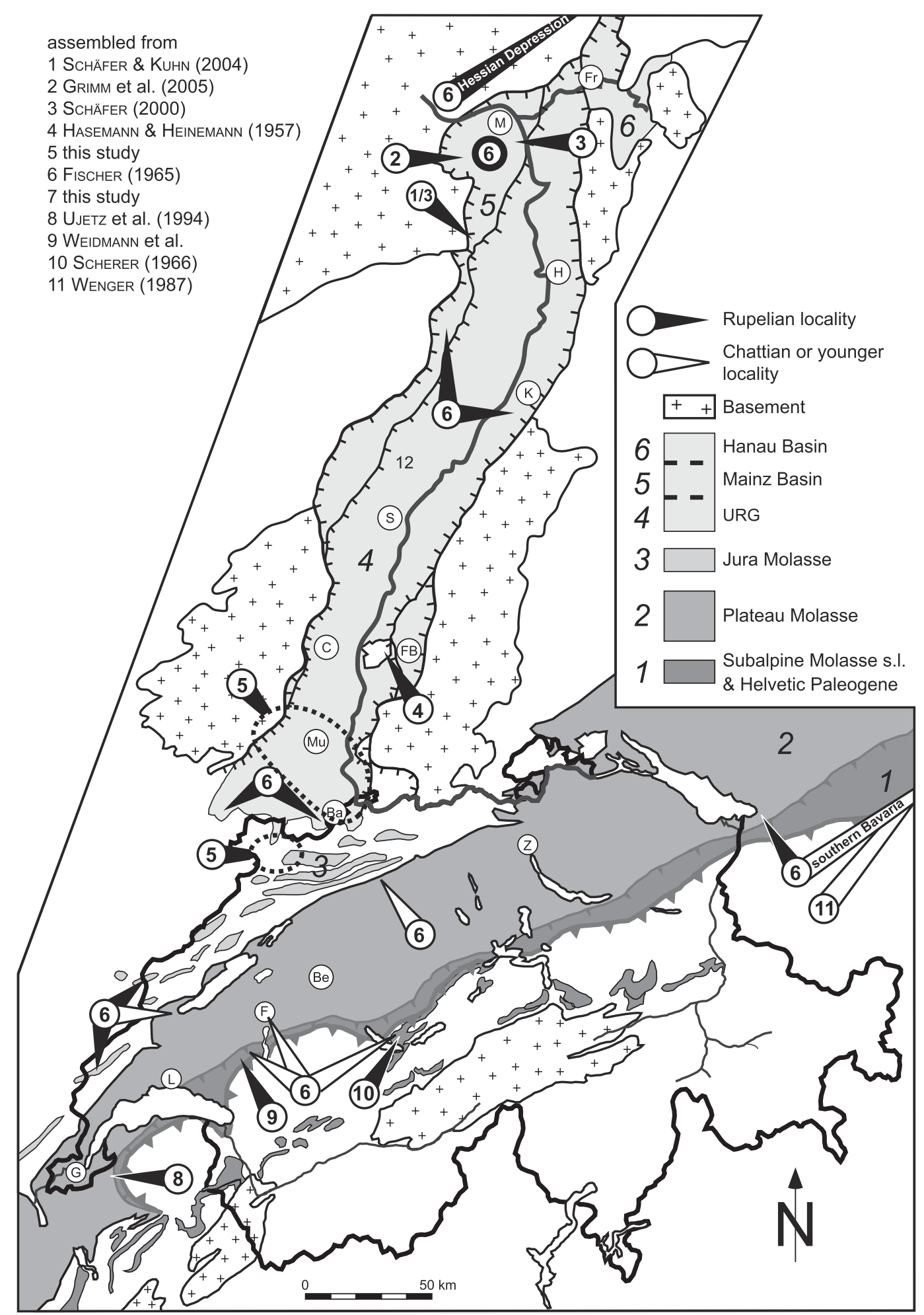

Text-fig. 12: Distribution of localities containing reworked planktonic Foraminifera and possible source localities in the Upper Rhine Graben, the Swiss Molasse Basin, the subalpine Molasse and the Helvetic Paleogene 


\subsection{This study}

7.2.1 Stratigraphic distribution of the reworked material in the research area

Compared to Fischer (1965a), the two drill cores Allschwil-2 and DP-202 and the outcrops Eguisheim ("Marnes à foraminifères"), Retzwiller (upper "Couches à Melettes") and Wessenberg ("Molasse alsacienne") extend the stratigraphic coverage. The range of evidently reworked Foraminifera is thereby also extended. The onset of reworked material at the drilling sites DP-202 and Allschwil-2 starts in the middle "Couches à Melettes" and in the basal "Couches à Melettes" respectivly (Text-figs. 6, 11).

The onset of reworked Foraminifera coincides with the second lithological unit ("Couches à Mélettes") of the second Rupelian transgression of the Upper Rhine Graben. According to BERGGREN et al. (2006) the Late Middle Eocene to Late Eocene (P12 - P15) ranging species Acarinina echinata (Text-fig. 8; Plate 18, fig. 1) recorded from the "Marnes à foraminifères" possibly ranges into the Oligocene. Thus its status as reworked species is under consideration.

Four consecutive, increasingly diverse and abundant episodes characterize the reworking in the drill core Allschwil-2. All four events are generally linked to increased clastic input and include Late Cretaceous and Paleogene taxa. The four pulses relate to the lowermost and middle "Couches à Melettes", the "Marnes à Cyrènes" as well as scarce occurrences within the lacustrine Niederroedern Beds.

The reworked Foraminifera of the drilling DP202 are less clearly linked to increasing clastic input, though the general trend can also be observed. A single event (sample W-45) derived from the middle "Couches à Melettes" is followed by two more or less brief episodes in the upper "Couches à Mélettes". With the overall increase in clastic input the diversity and abundance of reworked specimens rises throughout the "Marnes à Cyrènes". Cretaceous species only occur in the upper part of this stratigraphic unit. A single isolated sample from the Niederroedern Formation (W-12) yielded one Paleogene species (Text-fig. 7).

Eocene and Cretaceous material is also reported from the clay pit Retzwiller ("Couches à Mélettes"; Text-fig. 10) and the outcrop Wessenberg ("Molasse alsacienne"; both Sundgau, E France).
7.2.2 Magnitude and range of reworked planktonic Foraminifera

The samples from the research area yielded 10 Cretaceous (Text-fig. 14) and 21 Eocene (Text-fig. 13) reworked, rather well preserved taxa. Species with a predominantly Lutetian range represent by far the most abundant group (e.g., Acarinina bullbrooki [Plate 13, fig. 4], A. rugosoaculeata [Plate 14, fig. 4]; see Textfigs. 15, 16). Only one Ypresian (Morozovella subbotinae [Plate 15, figs. 1, 2]) and three post-Lutetian (e.g., Turborotalia cocoaensis) species occur in the research area. The single Paleocene species Chiloguembelina midwayensis (Plate 15, fig. 5) is rare and poorly preserved. Several Eocene to Oligocene / Miocene, biostratigraphically important species are potentially reworked. Most occurrences of the latter like Subbotina utilisindex and Pseudohastigerina micra are linked to reworking events and are thus supposed to be of allochthonous origin (see chapter 5.2).

The essentially Late Cretaceous species concentrate on three intervals; a Cenomanian (e.g., Rotalipora brotzeni [Plate 13, fig. 2]), a Turonian to Santonian (Marginotruncana pseudolinneiana [Plate 12, figs. 8, 9]) and a Campanian to Maastrichtian (e.g., Heterobelix striata) interval (Text-fig. 17). The Turonian to Santonian interval is only observed at the outcrop Retzwiller (Text-figs. 10, 14).

No clear age-trends can be observed in the reworked assemblages. In the upper part of the drilling Allschwil-2 ("Marnes à Cyrènes" and Niederroedern Formation) a slight shift from Lutetian towards Lutetian to post-Lutetian ranging species is apparent. At the DP-202 drill site the trend tends to be reversed, from Late Lutetian and Priabonian species in sample W-45 to predominantly Lutetian and Ypresian as well as Cretaceous species in the samples W-20 and W-18. Both samples from the clay pit Retzwiller cover the whole Eocene range (Morozovella subbotinae, Globigerinatheka semiinvoluta). The outcrop Wessenberg is rather restricted to a Bartonian to Priabonian age (Turborotalia cocoaensis, Subbotina eocaena).

Fischer (1965a) lists 26 corroded Cretaceous and about 16 Eocene, relatively well preserved species (without open taxa). According to FISCHER (1965a), the stages Cenomanian, Turonian, Campanian, Maastrichtian and Lutetian to Priabonian are confirmed. SCHÄFER \& KUHN (2004) report 38 Cretaceous and 38 Paleocene to Eocene species (without open taxa). Identical taxa of both references and the research area are listed in Table 1. 


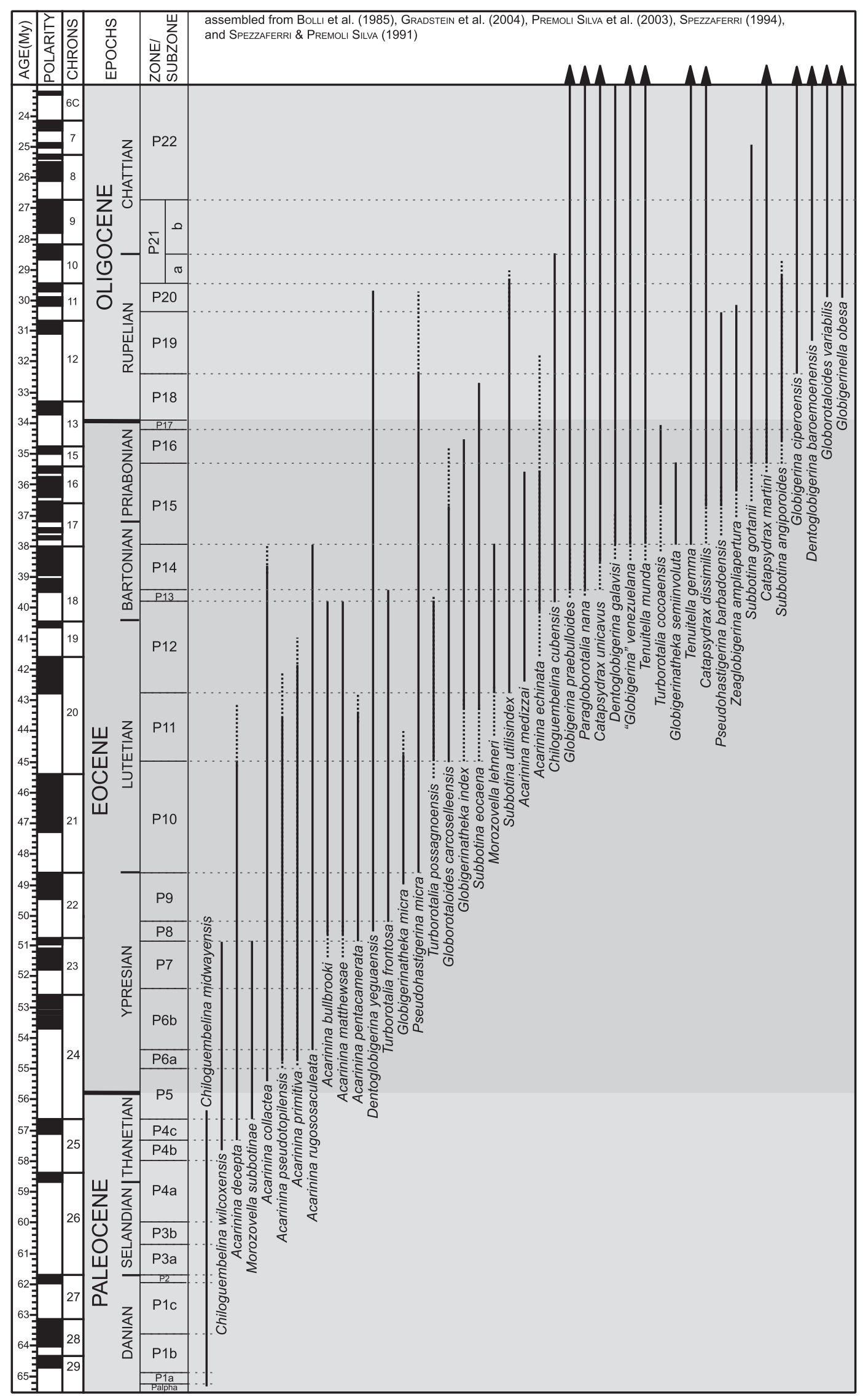

Text-fig. 13: Biostratigraphic ranges of recorded Paleogene planktonic Foraminifera species. 


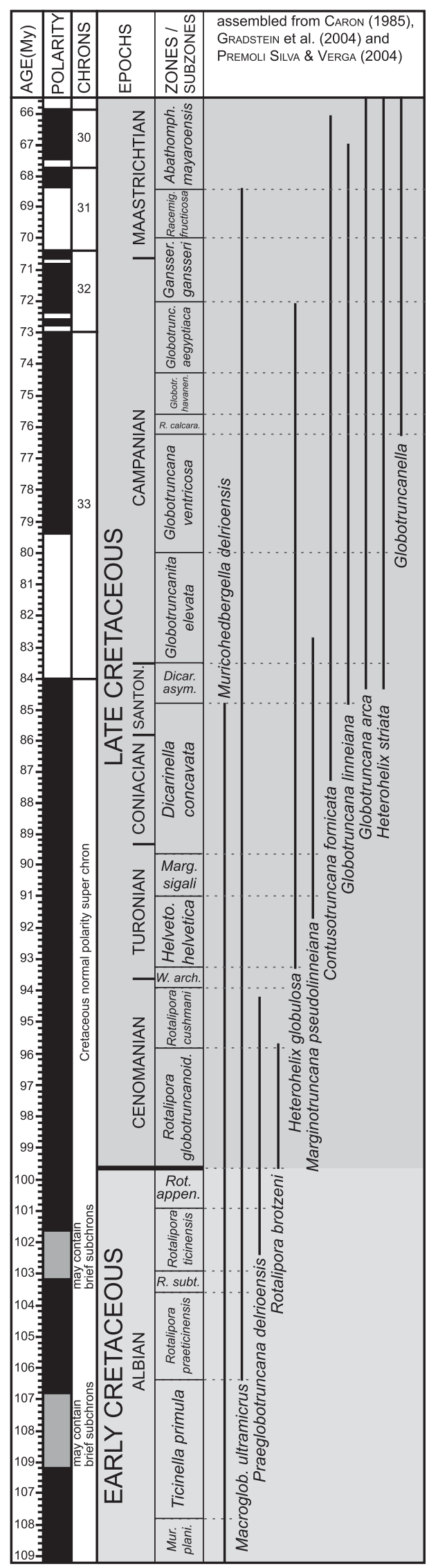

Text-fig. 14: Biostratigraphic ranges of recorded Cretaceous planktonic Foraminifera species. 


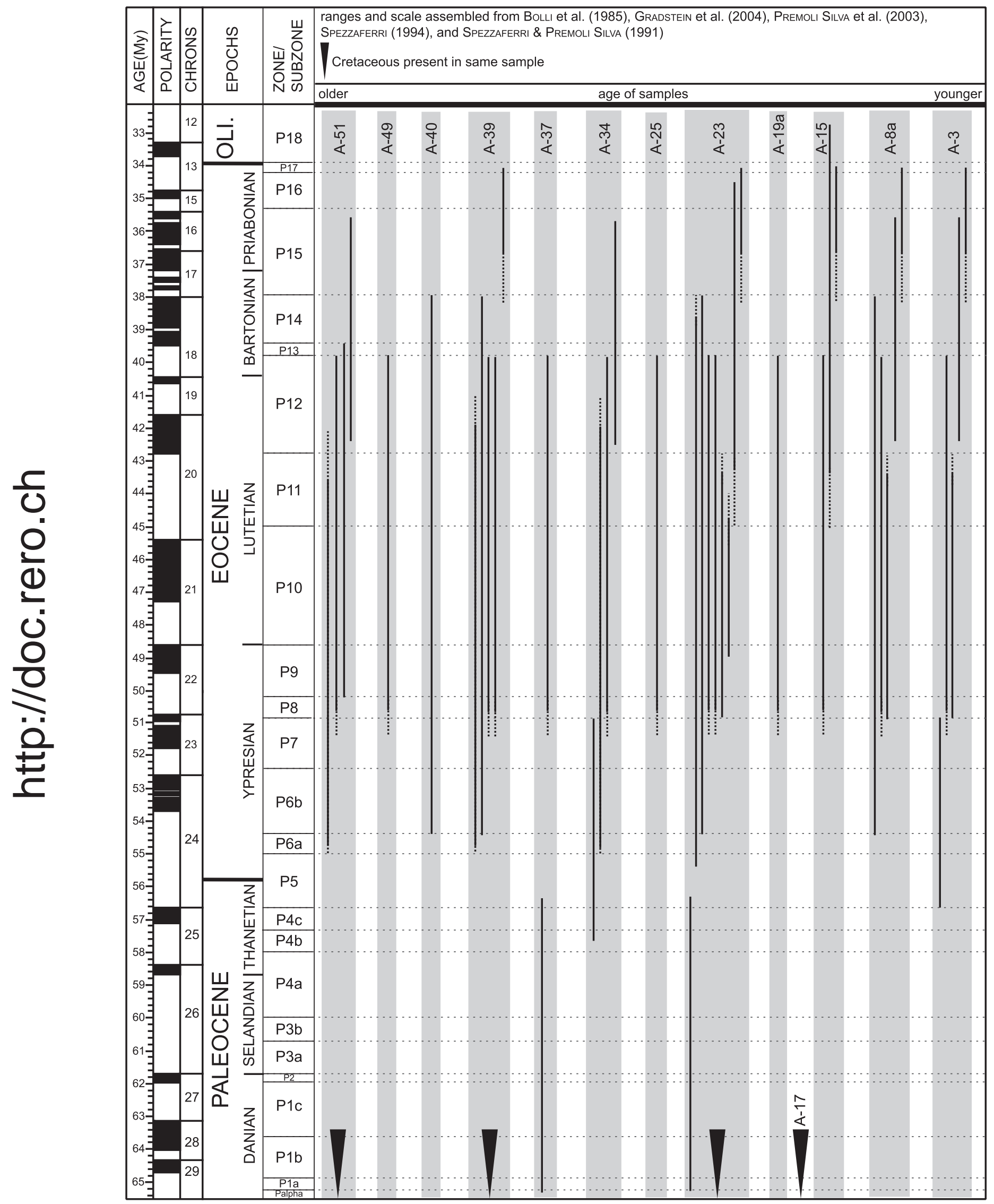

Text-fig. 15: Per sample distribution of reworked planktonic Foraminifera species ranges (Eocene drilling Allschwil-2). Greatest overlap indicates the most likely source age(s). 


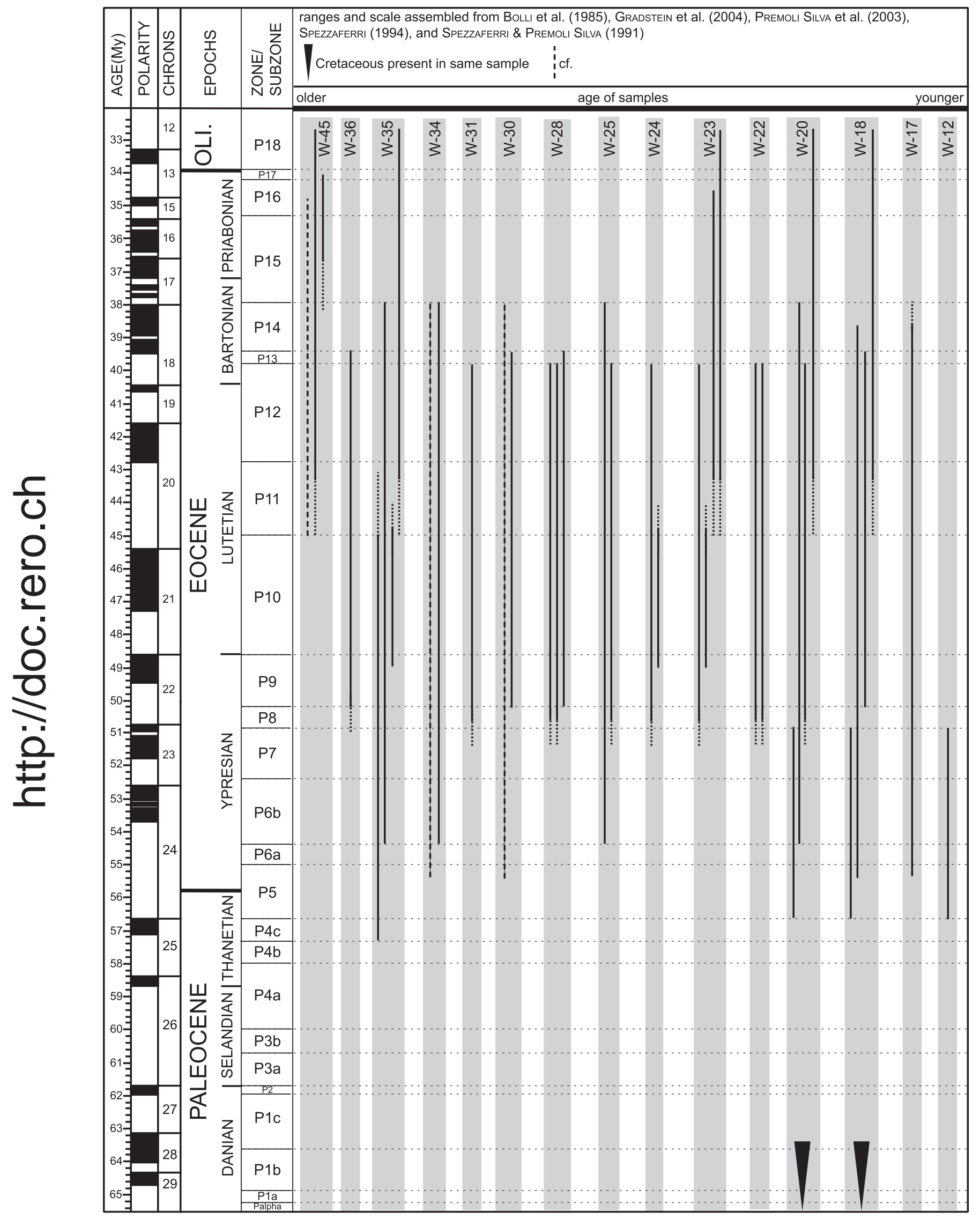

Text-fig. 16: Per sample distribution of reworked planktonic Foraminifera species ranges (Eocene drilling DP-202). Greatest overlap indicates the most likely source rock age(s). 


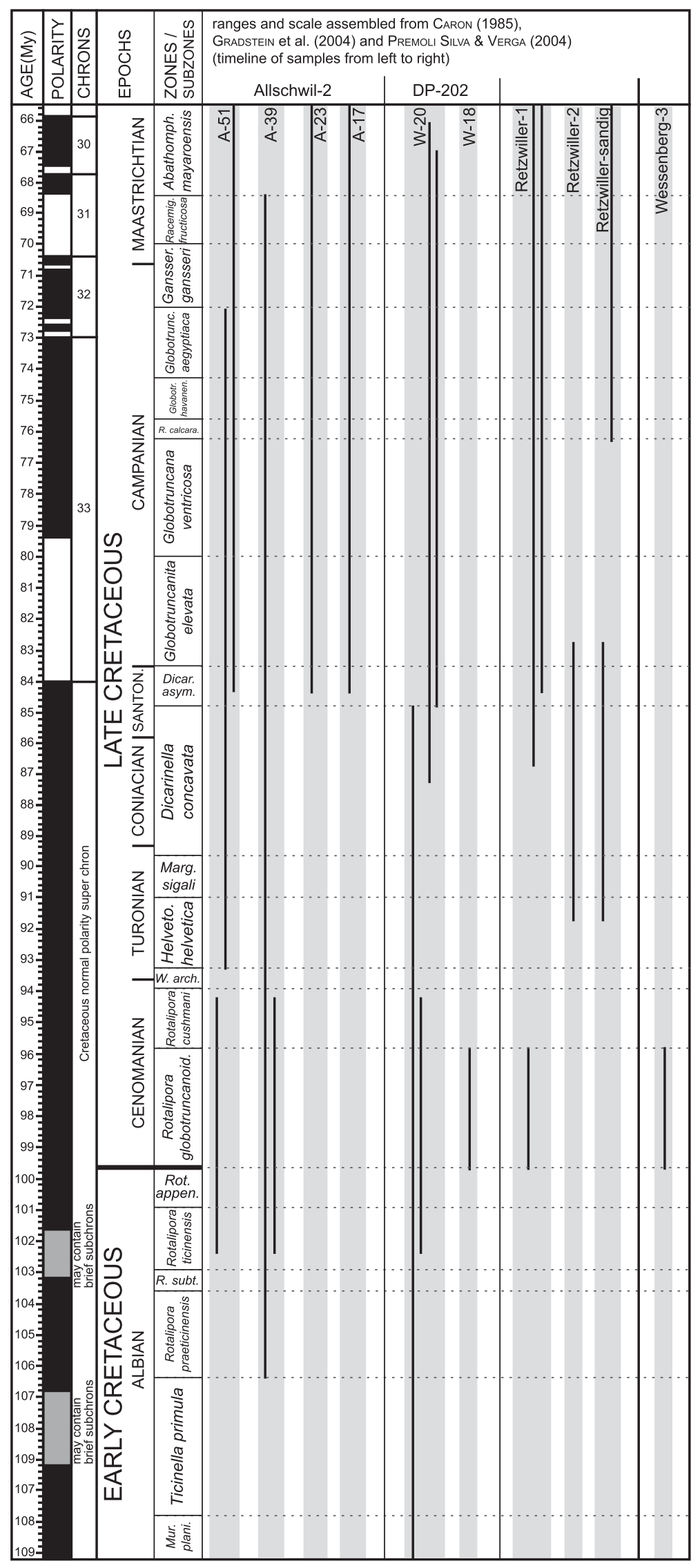

Text-fig. 17: Per sample distribution of reworked planktonic Foraminifera species ranges (Cretaceous). Greatest overlap indicates the most likely source rock age(s). 


\begin{tabular}{|c|c|c|}
\hline FISCHER (1965) & this study & author \\
\hline \multicolumn{3}{|l|}{ Cretaceous: } \\
\hline Heterobelix striata & Heterohelix striata & (EHRENBERG) \\
\hline Heterohelix globulosa & Heterohelix globulosa & (EHRENBERG) \\
\hline Praeglobotruncana delrioensis & Praeglobotruncana delrioensis & (Plummer) \\
\hline Rotalipora brotzeni & Rotalipora brotzeni & (SIGAL) \\
\hline Globotruncana linneiana & Globotruncana linneiana & (D'ORBIGNY) \\
\hline Globotruncana fornicata & Contusotruncana fornicata & (Plummer) \\
\hline Globotruncana cf. arca & Globotruncana arca? & (CUSHMAN) \\
\hline \multicolumn{3}{|l|}{ Paleogene: } \\
\hline Globorotalia bullbrooki & Acarinina bullbrooki & (BOLLI) \\
\hline Globorotalia cf. subbotinae & Morozovella subbotinae & (Morozova) \\
\hline Globorotalia pseudotopilensis & Acarinina pseudotopilensis & (Subbotina) \\
\hline Globorotalia opima nana & Paragloborotalia nana* & (BOLLI) \\
\hline Globorotalia rugosoaculeata & Acarinina rugosoaculeata & (SubBotina) \\
\hline Globigerina primitiva & Acarinina primitiva & (FINLAY) \\
\hline Globigerina praebulloides* & Globigerina praebulloides* & BLOW \\
\hline Globigerina ampliapertura* & "Zeaglobigerina" ampliapertura* & (BOLLI) \\
\hline Globigerinita unicava* & Catapsydrax unicavus* & $\begin{array}{l}\text { (BOLLI, LOEBLICH \& } \\
\text { TAPPAN) }\end{array}$ \\
\hline SCHÄFER \& KUHN (2004) & this study & author \\
\hline \multicolumn{3}{|l|}{ Cretaceous: } \\
\hline Globotruncana? arca & Globotruncana arca? & (CUSHMAN) \\
\hline Globotruncana fornicata & Contusotruncana fornicata & (Plummer) \\
\hline Globotruncana cf. linneiana & Globotruncana linneiana & (D'ORBIGNY) \\
\hline Marginotruncana pseudolinneiana & Marginotruncana pseudolinneiana & Pessagno \\
\hline Rotalipora brotzeni & Rotalipora brotzeni & (SIGAL) \\
\hline \multicolumn{3}{|l|}{ Paleogene: } \\
\hline Acarinina bullbrooki & Acarinina bullbrooki & (BOLLI) \\
\hline Acarinina primitiva & Acarinina primitiva & (FINLAY) \\
\hline Acarinina pseudotopilensis & Acarinina pseudotopilensis & (SubBotina) \\
\hline Globigerinatheka subconglobata micra & Globigerinatheka micra & (SHUTSKAYA) \\
\hline Morozovella subbotinae & Morozovella subbotinae & (Morozova) \\
\hline Pseudohastigerina micra & Pseudohastigerina micra* & (Cole) \\
\hline Turborotalia cerroazuelensis cocoaensis & Turborotalia cocoaensis & (CUSHMAN) \\
\hline
\end{tabular}

\subsection{Discussion of source areas}

\subsubsection{Cretaceous}

Widespread Late Cretaceous sedimentation took place on the Helvetic shelf and adjacent areas around the Rhenish Massif (Dercourt et al. [eds.] 2000). Prior to the initial Paleogene sedimentation, the entire
Cretaceous succession was eroded within the research area and adjacent areas to the south (e.g., northern Jura region). This lead to the deposition of the terrestrial-lacustrine Lutetian to Priabonian Siderolithic clays directly within and on karstic Late Jurassic limestones (e.g., BERGER et al. 2005a, b). At the drill site Allschwil-2 a basal unit of red clays containing piso- 
lithic ore ("Siderolithic") lies discordantly on Late Jurassic oolithic carbonates. A Late Jurassic/Lower Cretaceous - Eocene unconformity also exist in the northwestern Helvetic Realm (e.g., Herb 1988, BERgER et al. 2005b). This implies an origin of Late Cretaceous planktonic Foraminifera located further to the South or the Southeast. FISCHER (1965a) proposed marginal alpine source rocks like the "Couches rouges" of the "Klippen"-belt. More recently this has however been contradicted by BERGER (1995), as an alpine source would imply the reworking of older than Late Cretaceous planktonic Foraminifera. In the Jura region deeper marine conditions necessary for the occurrence of planktonic Foraminifera were only established by the Albian or Cenomanian (BERGER 1995).

\subsubsection{Paleogene}

The Lutetian succession of the Upper Rhine Graben lacks marine sediments (e.g., Allschwil-2 borehole, this study; BERGER et al. 2005a, b, SisSINGH 1998) and lies discordantly on Late Jurassic oolithic limestones. Therefore, a Late Rupelian erosion of local pre-Priabonian marine deposits caused by regional marginal (relative) uplift due to synrift movements can be excluded. A single enigmatic, rather poorly preserved foraminiferal assemblage indicating a Priabonian age (e.g., Globigerinatheka semiinvoluta, Turborotalia cocoaensis) is found in the basal "Rote Leitschicht" of the drill site Bremgarten-1 near Freiburg i. Br. (Ohmert 1993; Text-fig. 23, map c). The planktonic species are associated with abundant benthic taxa that indicate shallow water conditions (e.g., Elphidium spp., Pararotalia spp.). The planktonic species are abundant and similar to those found in the Late Eocene "Globigerinen-Schiefer" of central Switzerland (ECKERT 1963). Furthermore, the benthic assemblage is relatively small-sized. Therefore OHMERT (1993) suggest a deposition induced by a short-term shallow marine ingression from the North Alpine Foreland Basin. The abraded, supposedly autochthonous species preserved within small fragments of clastic matrix, the occurrence of few "Globotruncana" spp. and the presence of Jurassic limestone pebbles however may also indicate a deposition as (fluviatile) erosional residues. At the drill site Allschwil-2 located further to the south, equivalent sediments are free of microfossils. SissingH $(1998,2003,2006)$ proposes successive Priabonian to Early Rupelian ingressions via the Bresse Graben in the southwest and the intermediate transfer zone.

The northwest European Tertiary Basin (e.g., Lower Rhine Embayment, N German Basin) is ruled out as origin for reworked Paleogene species for several reasons. The Eo-Oligocene successions of the adjacent basins (France, Belgium, N Germany, England) are generally well developed and were not exposed to widespread erosion in the late Rupelian (VINKEN et al. 1988). Furthermore, in the adjacent Tertiary basins abundant planktonic species are absent (see FISCHER 1965a) and the basins may have been palaeogeographically isolated (e.g., between Lower Rhine Embayment, Neuwied and Mainz Basin; Meulenkamp et al. 2000, SissingH 2003). Finally, long distance transportation and the direction of sedimentary discharge in the Late Rupelian of the research area (deltaic system; Roussé 2006) all present problems for a supply from the north.

Though a stepwise northwestward progression of the Helvetic shelf and the adjacent foreland bulge is observable in the Paleocene and Eocene (e.g. HERB 1988, Kempf \& Pfiffner 2004, Lihou 1995, SinCLAIR 1996), marine sediments apparently were never deposited as far north as necessary (e.g. the future Swiss Jura region) to be subject to a Late Rupelian outer-alpine uplift and erosion.

Fischer (1965a), SChäFer \& KuHN (2004) and Roussé (2006) propose an alpine source for the allochthonous Paleogene faunas in the Late Rupelian. Widespread deep marine marls and sandstones to shallow marine carbonates, which could act as a possible source, were deposited in the Helvetic realm during Paleocene and Eocene times (e.g., Herb 1988, Lihou 1995, Menkveld-Gfeller 1995). Reworked Cretaceous and Lutetian to Priabonian faunal elements are found in Rupelian sediments of the Swiss Molasse Basin (e.g., Scherer 1966, Ujetz et al. 1994). Therefore, the Helvetikum must already to some extent have been affected by uplift (mesoalpine orogeny) and erosion by the Rupelian.

FISCHER (1965a) and SISSINGH (1998) suggest a marine sediment supply via the "Raurachian" depression (east of Basel). The latter possibly connected the Molasse Basin with the southern Upper Rhine Graben in the late Rupelian. This constellation would imply that eroded material was primarily deposited into the North Alpine Foreland Basin. Further transport against an eastern trending axial marine drainage system over the elevated foreland bulge into the southern 


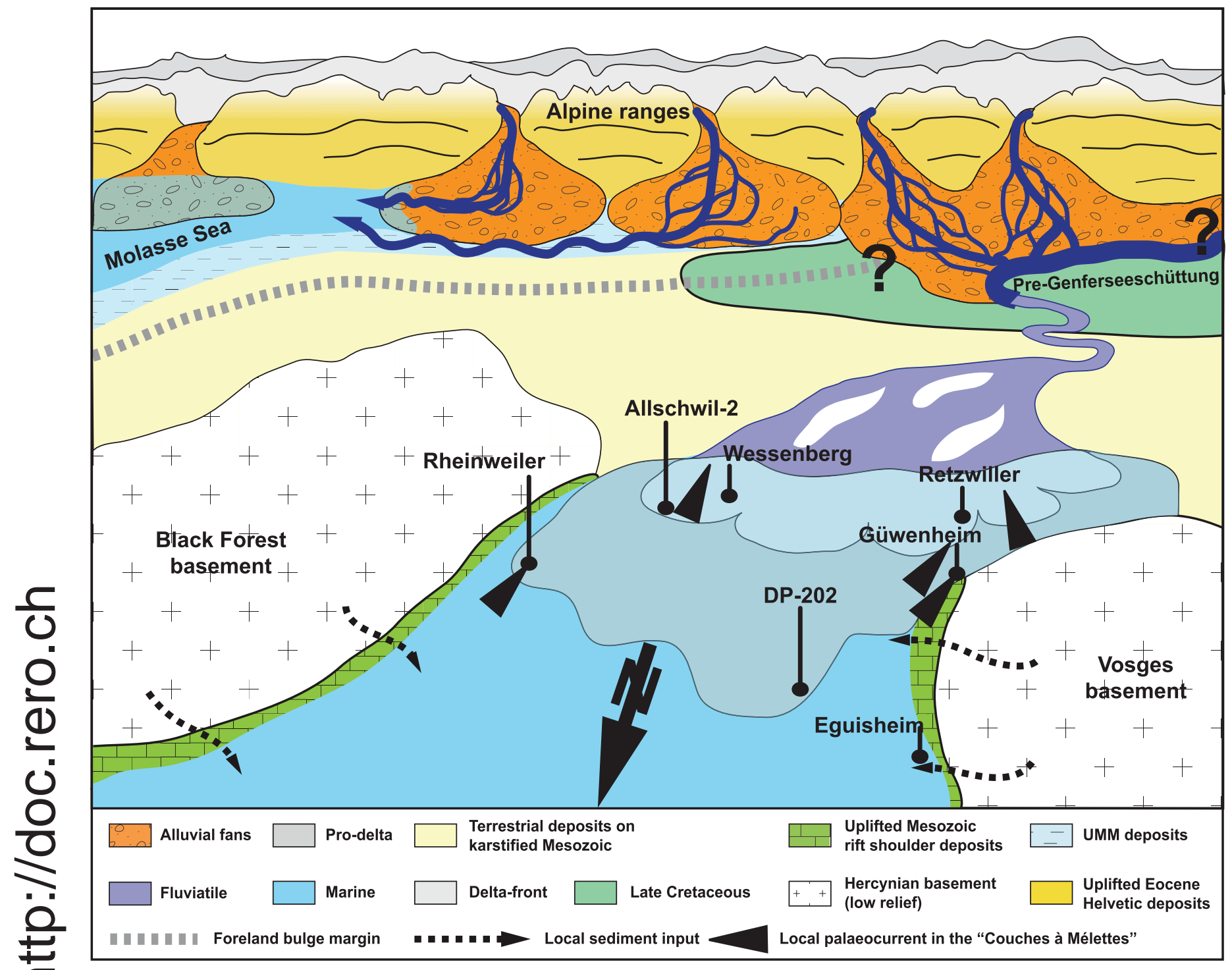

Text-fig. 18: Palaeopanoramic interpretation of the southernmost Upper Rhine Graben deltaic system, the southwestern Molasse Sea and the developing Alps in the Late Rupelian.

Upper Rhine Graben by means of marine currents only seems rather unlikely.

SCHÄFer \& KuHn (2004) and Roussé (2006) assume a fluviatile source with direct alpine origins.

While a direct alpine provenance seems to represents the most likely solution, the timing of the retreat of the Lower Marine Molasse (UMM) sea is critical. According to Berger (1995) and BERger et al. $(2005 a, b)$, the sea of the Lower Marine Molasse already retreated as far to the east as central Switzerland in the Late Rupelian (NP24). Linked with the increased rate of the late mesoalpine orogeny (SISSINGH
1998, 2003), a fluviatile system ancestral to the Chattian "Genferseeschüttung" fed by the first alluvial fans within rising Helvetic units may have developed. This system could have already supplied the persistent marine Southern Upper Rhine Graben with clastic material in the lower "Couches à Mélettes". The installation of an extensive deltaic system (Text-fig. 18) at the debut of the "Couches à Mélettes" has been demonstrated by Roussé (2006). The sedimentary structures like flute casts, sole structures and flow ripples throughout the research area (e.g. Güwenheim, Rheinweiler) and the adjacent Laufen Basin have an exclusively north- 
wards orientation. The sedimentary architecture indicates progressive pro-delta, delta-front, estuarine and fluviatile deposits. Both structures and architecture confirm a vast river system discharging northwards into the southern Upper Rhine Graben area during Late Rupelian and Chattian times.

\subsection{Conclusions}

The presence of dominantly Lutetian and additionally Ypresian, Priabonian and Late Cretaceous assemblages implies erosion of sediments of corresponding age south or southeast to the southern Upper Rhine Graben in the Late Rupelian (NP24; mid P2021a). The most likely source of the reworked Eocene species lies within the Helvetic realm. Therefore, a considerable uplift linked to the late mesoalpine orogeny, must already have taken place by this time. In the western part of the Swiss Molasse Basin vast alluvial fans consequently started to develop over the fan-deltas and sediments of the rapidly regressing Lower Marine Molasse (UMM) sea. The general WSW - ENE axial drainage pattern within the Basin was shortly thereafter redirected in the narrower southwestern part of the basin by sediment overfill. While the ENE regressing Molasse Sea continued to be fed by axial tributaries, the massive clastic accumulations in the southwestern part of the Swiss Molasse Basin overrode the relief of the foreland bulge and induced a northwards trending drainage system (Text-figs. 18, 25). Intermediately situated Late Cretaceous sediments were correspondingly subjected to fluviatile erosion and may have acted as source area of the accordingly reworked taxa (Text-fig. 18). With the onset of turbiditic pro-delta sedimentation in the lower "Couches à Mélettes" the link between the source area and the Upper Rhine Graben was established. More localised temporary flash flood events could explain the predeltaic occurrence of a single reworked species in the slightly earlier "Marnes à foraminiferes" at the outcrop Eguisheim. While the more southern drill site Allschwil-2 was affected earlier by allochthonous species than the drilling DP-202, both localities registered a maximum of reworking in the upper part of the "Marnes à Cyrènes".

Some $300 \mathrm{~km}$ to $350 \mathrm{~km}$ further north of the study area abundant similar Eocene and Cretaceous species are recorded from the Mainz Basin by SCHÄFER $\&$ Kunn (2004) at the base of the Stadecken Formation (upper "Couches à Mélettes" equivalent). This indicates very low delta-front gradients and relatively rapid submarine progradation within the laterally restricted Graben boundaries. Long distance turbiditic suspension transport could explain the relatively good preservation of the material.

The rarer occurrence of allochthonous fauna in the ?Latest Rupelian to Early Chattian fluviatile to lacustrine Niederroedern Formation of the southern Upper Rhine Graben may be due to increased abrasion within the generally coarse grained sediments, or the shift to different source areas lacking planktonic Foraminifera. Abundant reworked species are however recorded from numerous localities in the Chattian Lower Freshwater Molasse (USM) of Switzerland and southern Germany.

\section{Palaeoecology}

\subsection{The "Zone Fossilifère" (Early Rupelian)}

Only a few, generally rather poorly preserved species of benthic Foraminifera occur in the lower part of the "Zone fossilifère" (samples A-155 to A-142) at the Allschwil-2 drill site. Deeper marine taxa as Praeglobobulimina coprolithoides (Plate 7, fig. 13) and Bolivina cf. B. crenulata (Plate 7, fig. 7) are restricted to the sample A-155 at the base of the unit. According to Spezzaferri \& Coric (2001), the Praeglobobulimina group and the Bolivinids, characterised by a large surface area, give an inner shelf to upper bathyal depth estimate and indicate reduced oxygen conditions.

The rare occurrence of Porosononion sp., Flintina cf. F. variolaria (miliolid; Plate 4, fig. 10) and Cibicidoides oligocenicus (attached epifauna, hard substrates; Plate 9, fig. 10) in the subsequent two samples suggest a shallower, well-oxygenated environment. The infracircalittoral Porosononion granosum is attributed to habitats influenced by high water energy and / or lowered salinities. This may indicate the beginning of an increased freshwater influx into the basin. It coincides with the presence of poorly preserved specimens of Limnocythere sp. within an otherwise marine ostracod fauna.

The scarce data from the research area is in good accord with the information on the isochronous Middle Pechelbronn Beds of the Mainz Basin located in the northernmost part of the Upper Rhine Graben. Bolivina sp., Bulimina coprolithoides and Cibicides sp. are recorded from the lower part of the aforementioned unit (RADTKE et al. 2006). Additional fully marine taxa from the Middle Pechelbronn Beds like 
Bolivina beyrichi and Cyclammina placenta are listed in GRIMM 2002.

\subsection{The lowermost "Série grise": "Marnes à foraminifères" (Late Rupelian)}

\section{Overview}

The presumably short interval of the "Marnes à foraminiferes" yields the most abundant and diverse fauna of benthic Foraminifera within the research area. It represents the initial flooding of the second Rupelian transgression into the Upper Rhine Graben. In contrast to the well-preserved benthic species the planktonic taxa, though abundant, are poorly preserved and thus difficult to determine. The maximum diversity of 39 benthic and 3 planktonic species was found in sample 3 of the marginal outcrop Eguisheim. The overall diversity of the "Marnes à Cyrènes" amounts to 67 benthic and 5 planktonic species of Foraminifera.

The textulariids, rotalids and lagenids represent the most important groups. Miliolids and buliminids as well as smooth branching or coiled agglutinated species play a less important role (Text-figs. 4-7, 19-21). As many species from the research area range throughout the "Marnes à foraminiferes", a clear subdivision of the unit as reported within the Mainz Basin (e.g., Grimm 1998, 2002) is only partly possible (Text-fig. 19).

Some trends however can be observed:

1. Karreriella siphonella exilis (Plate 3, figs. 8-10) and Nodosaria capitata striatissima (Plate 5, fig. 5) only occur in the lower part of the "Marnes à foraminifères".

2. Spiroplectinella carinata (Plate 2, figs. 9-11) and Heterolepa dutemplei (Plate 10, fig. 10) are missing in the uppermost samples of the unit.

3. Bolivina spp. only appears in the upper part of the "Marnes à foraminifères".

4. Trochammina spp. and the Cibicidoides group never occur in the basal samples.

The "Marnes à foraminiferes" at the Allschwil-2 drill site are characterized by a general increase of diversity and near absence of miliolids. At the drill site DP-202 miliolids are present throughout the unit and show a drop in diversity in the middle part. As the species from trend 1 and 2 (see above) are missing from the incomplete succession at the locality Eguisheim, the latter faunistically relates to the upper part of the basinal "Marnes à foraminiferes".

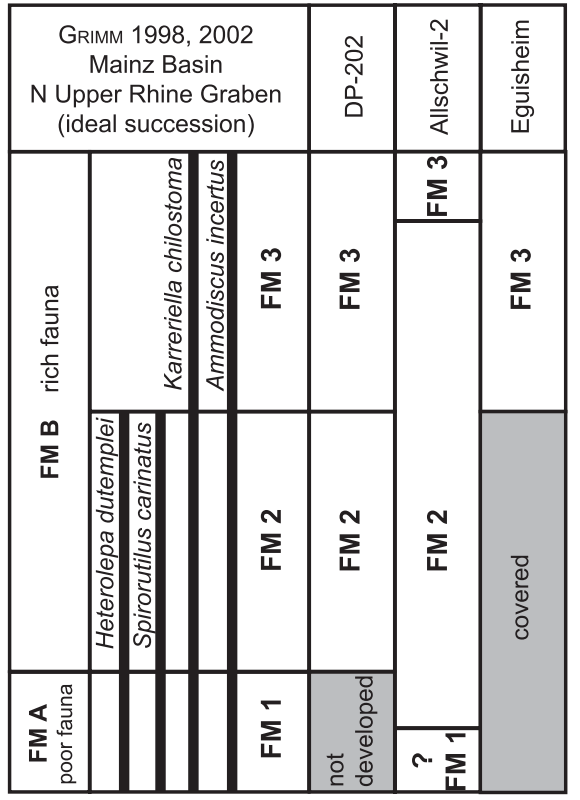

Text-fig. 19: Comparison of the "Marnes à foraminiferes" units sensu Grimm $(1998,2002)$ of the study area (South) and the Mainz Basin (North)

\section{Palaeoenvironment \\ (Text-figs. 20-22)}

The agglutinated Foraminifera are dominated by detritivore or bacterivore epifaunal and infaunal species (e.g., Ammodiscus incertus [Plate 1, fig. 6], Sabellovoluta bumboldti [Plate 2, figs. 1-3], Repmanina charoides [Plate 1, figs. 7,8$]$ ). Erect tubular or branching suspension feeders (Bathysiphon taurinensis [Plate 1, fig. 1], Rhizammina? sp. [Plate 1, fig. 3], Hyperammina sp. [Plate 1, fig. 2]) indicating reduced water turbulence and attached herbivores (some Trochamminids) are rare or absent. Compared to data assembled from recent Foraminifera assemblages (Jones \& CHARNOCK 1985), the distribution of agglutinated Foraminifera from the research area indicates upper bathyal to outer shelf habitats throughout the "Marnes à foraminiferes" (Text-figs. 20-22). Only at the drill site DP-202 a slight shallowing up from upper bathyal zone to outer shelf may be deduced.

Though the individual species mostly show wide depth distributions (shelf to bathyal zone), the range can be narrowed down to $200 \mathrm{~m}$ to $500 \mathrm{~m}$ water depth according to data from RöGL \& SPEZZAFERRI (2003) and Spezzaferri et al. (2004). Indicative taxa include Karreriella chilostoma (200 m to $1000 \mathrm{~m}$; Plate 3, figs. 4, 5), Reophax scorpiurus (Plate 1, fig. 9) and 
Fig. 20 Eguisheim

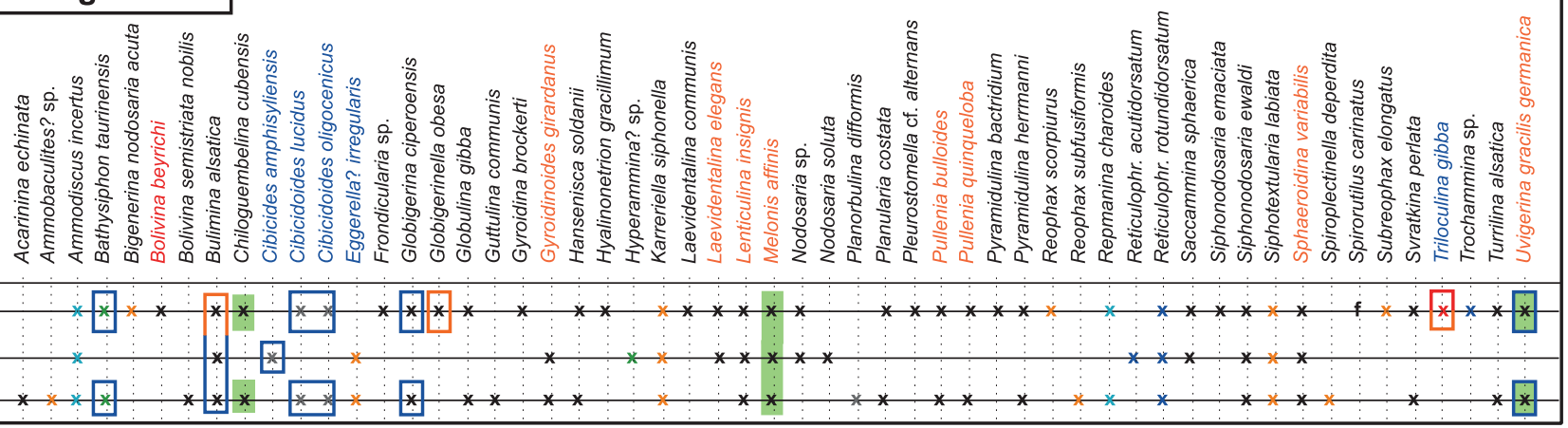

Fig. 21 Allschwil-2
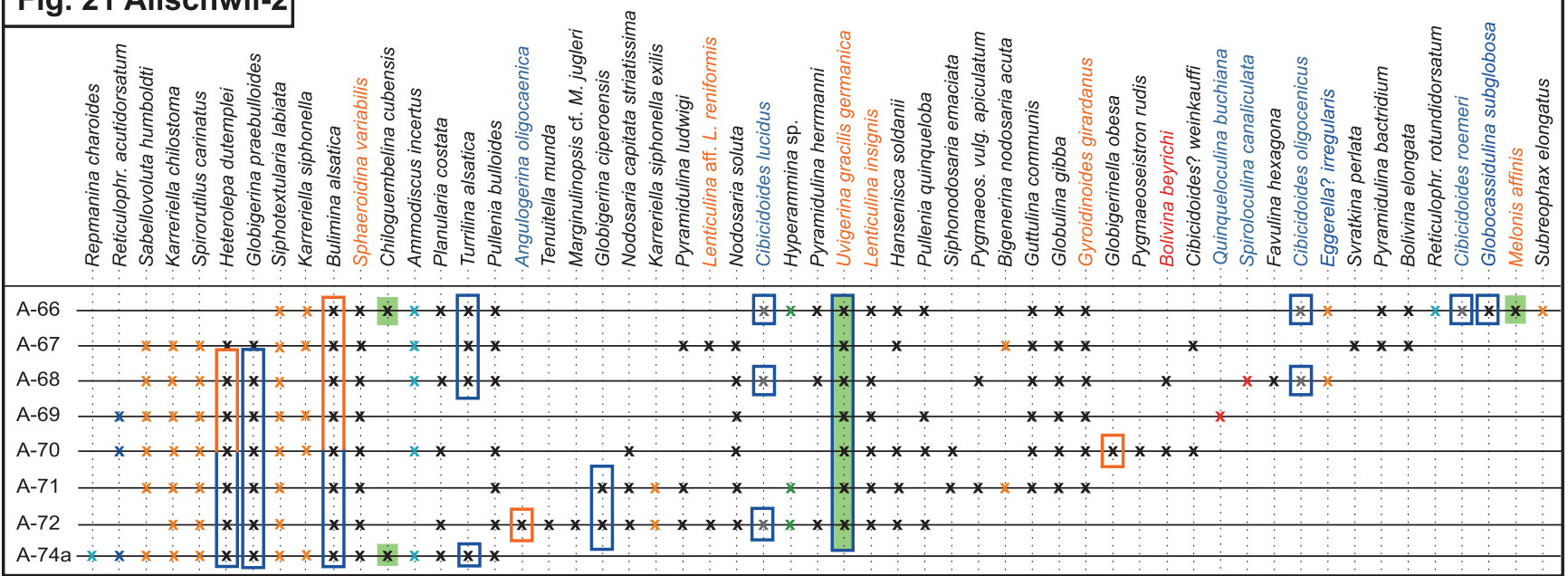

Fig. 22 DP-202

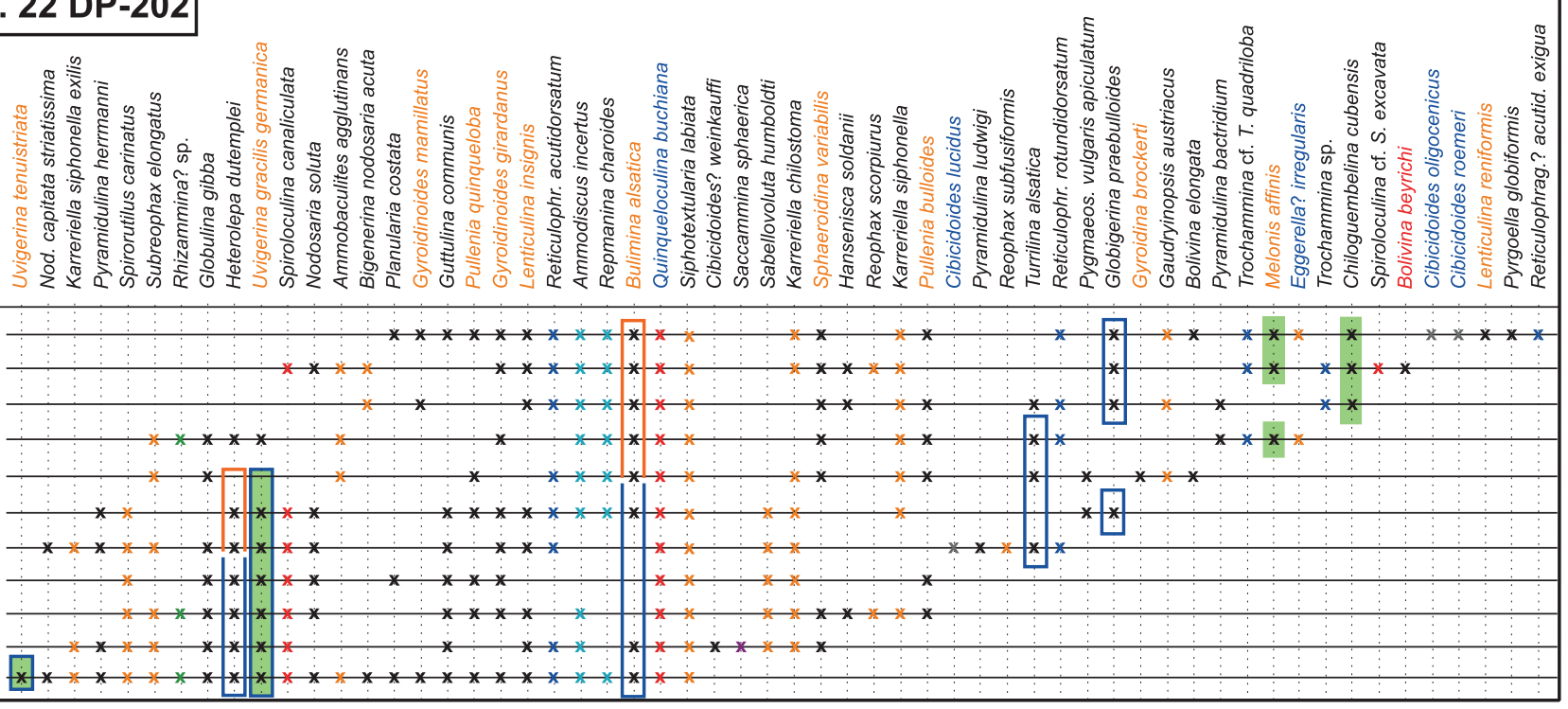

$x$ attached epifauna, hardgrounds

$x$ A erect suspension feeders

x $\quad B_{1}$ epi- to infunal passive deposit feeders

$x \quad B_{2}$ epifaunal active deposit feeders

x $\quad B_{3}$ epifaunal active herbivores, detritivores, omnivores

$x \quad C_{1}$ infaunal detritivores, bacterial scavengers (Textulariids et al.)

x $\mathrm{C}_{2}$ infaunal detritivores, bacterial scavengers (Miliolids)

sample distances to scale, $1 \mathrm{~cm}=1 \mathrm{~m}$

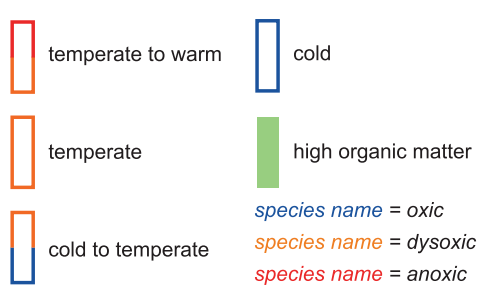

assembled from

GRIMM \& STEURBAUT 2001

HUBER 1994

JONES \& CHARNOCK 1985

RÖGL \& SPEZZAFERRI 2003

SCHÖNFELD 2001

SPEZZAFERRI 2004

SPEZZAFERRI \& CoRIC 200

SPEZZAFERRI et al. 2004

UJETZ 1996

Text-fig. 20: Palaeoecological parameters of benthic Foraminifera species from the "Marnes à foraminiferes" at the Eguisheim outcrop.

Text-fig. 21: Palaeoecological parameters of benthic Foraminifera species from the "Marnes à foraminiferes" at the Allschwil-2 drilling. Text-fig. 22: Palaeoecological parameters of benthic Foraminifera species from the "Marnes à foraminiferes" at the DP-202 drilling. 
Spiroplectinella carinata (30 m to $500 \mathrm{~m})$, Uvigerina spp. (100 m to $>4500 \mathrm{~m})$, Heterolepa spp. (25 m to $500 \mathrm{~m}$ ) and Melonis pompiliodes $(50 \mathrm{~m}$ to $4000 \mathrm{~m}$; closely related to M. affinis). The absence of Karreriella chilostoma at the locality Eguisheim may reflect shallower depths due to its more marginal position.

The presence of abundant infaunal species, "oxic" species (e.g., Cibicidoides spp., miliolids) and indicators of suboxic conditions (Uvigerina spp., Sphaeroidina spp., Gyroidinoides spp.) suggests generally welloxygenated, occasionally slightly depleted bottom waters (Text-figs. 20-22). The single rare, dysoxic species Bolivina beyrichi (Plate 7, figs. 3, 4) appears only in the upper part of the "Marnes à foraminiferes".

Water temperatures were generally low, as indicated by abundant cold (e.g., Turrilina alsatica [Plate 7, fig. 12], Cibicidoides spp., small Globigerinids) and cold to temperate water species (e.g., Bulimina alsatica [Plate 7, figs. 14, 15], Heterolepa dutemplei [Plate 10, fig. 10]).

A few species like Uvigerina gracilis germanica (Plate 8, figs. 1-3), Melonis affinis (RöGL \& SpeZzAFERRI 2003) and Chiloguembelina cubensis (HUBER 1994; Plate 15, figs. 7, 8) suggest slightly elevated nutrient / organic matter levels (Text-figs. 20-22).

The high abundance of buliminids, cibicidoids, textulariids, uvigerinids, Pullenia spp. and Sphaeroidina variabilisi (Plate 9, figs. 5, 6), amongst others represents a typically fully marine, normal saline Foraminifera assemblage (Grimm \& Steurbaut 2001, UjeTZ 1996).

The assemblages from the "Marnesà foraminifères" of the drill sites Leymen (eastern border of the Allschwil Graben; NW Switzerland) and Rheinach (west of the main eastern Graben fault), investigated by HuBER (1994), show quite similar distributions. The latter were interpreted to represent outer shelf to uppermost bathyal depths, in accordance with the cooccurrence of spinose planktonic Foraminifera like Globigerina praebulloides (Plate 16, figs. 2, 3). A well oxygenated water column and sediments respectively as well as a slowly increasing nutrient supply may be assumed. Comparable conclusions for the fauna of the "Marnes à foraminiferes" of the northern Upper Rhine Graben (Mainz Basin) were drawn by GRIMm (1994).

\subsection{The lower "Série grise": "Schistes à poissons" (Late Rupelian)}

\section{Overview}

At the boundary "Marnes à foraminiferes" / "Schistes à poissons" the lithology changes abruptly from greenish / brownish marls to a black / dark brown, finely laminated "paper schist". This change is also documented by a sudden decrease in diversity and abundance of the Foraminifera taxa. The total number of Foraminifera taxa in the research area consists of 2 planktonic and 23 benthic, mainly suboxic to dysoxic infaunal and epifaunal species. The abundant infaunal agglutinated Foraminifera present in the "Marnes à foraminifères” disappear (Text-figs. 4-7).

Oxic epifaunal elements are represented by dwarf species as for example Cibicides amphisyliensis (Plate 10, fig. 2). Only dysoxic or suboxic endo- to epifaunal elements like Bolivina beyrichi (Plate 7, figs. 3, 4), Siphonodosaria ewaldi (Plate 9, fig. 2) or Melonis affinis (Plate 10, fig. 5) are abundant and / or normally developed (Text-fig. 9). Other suboxic species like $G y$ roidina brockerti (Plate 11, fig. 1) and Gyroidinoides girardanus (Plate 11, fig. 2) display dwarfism or are limited to the lowermost part of the unit. Reticulophragmium? acutidorsatum exigua (Plate 2, fig. 6) is the only species of agglutinated Foraminifera and is exclusively recorded in one sample (W-65) at the base of the "Schistes à poissons" of the DP-202 drill site. Planktonic Foraminifera like Globigerina praebulloides are either absent (DP-202) or badly preserved and pyritised (Rheinweiler). Only in the uppermost part of the "Schistes à poissons" (Allschwil-2) they occur in higher abundance.

\section{Palaeoenvironment}

The abrupt sedimentary and faunal change implies a transition to suboxic, partially dysoxic or anoxic bottom conditions with simultaneously rising levels of organic matter. Truly anoxic events may be concluded from the high sample fraction devoid of fossils. A comparable zone with rare Foraminifera taxa in the upper part of the "Schistes à poissons" as observed by GRIMM (1994; FS B) in the Mainz Basin is not developed.

A shallower and more agitated environment may explain the higher diversity of the assemblage of the marginal outcrop Rheinweiler (SCHERLER 2005) compared to the basinal samples derived from the drill 
sites Allschwil-2 and DP-202. Similar or slightly deeper conditions as those assumed for the "Marnes à foraminiferes" are proposed by GRIMM (1994) and HUBER (1994). No definite statement of the palaeodepth is possible due to the general absence of depth specific species. Occasional records of well-preserved Aubignyna kiliani in each of the three localities may hint at slightly shallower environments (SPEZZAFERRI \& CORIC 2001).

Huber (1994) suggests a link between algal blooms and a high abundance of small Cibicides.

\subsection{The middle "Série grise": "Couches à Mélettes" (Late Rupelian)}

Overview

Planktonic Foraminifera, in particular Globigerina praebulloides, dominate the "Couches à Mélettes" with planktonic/benthic-ratios generally higher than $50 \%$. Agglutinated Foraminifera (including miliolids) are nearly absent. This may be related to an insufficient supply of coarser sediment material, as indicated by a single specimen of Karreriella chilostoma (Plate 3, fig. 4; sample A-34, Allschwil-2) that is entirely agglutinated of coccoliths. Calcareous benthic Foraminifera are more common at the Allschwil-2 drill site, but the record within the DP-202 core remains rather scattered. The more abundant taxa include Bulimina alsatica, Gyroidinoides girardanus, Turrilina alsatica and Aubignyna kiliani (Text-figs. 4-7).

\section{Palaeoenvironment}

The high ratio of planktonic Foraminifera suggests an open marine outer shelf or deeper water environment. The small Globigerinids and benthic taxa suggest rather cold water and suboxic bottom conditions.

\subsection{The upper "Série grise": "Marnes à Cyrènes" (Late Rupelian)}

\section{Overview}

The gradual sedimentary transition between the "Couches à Mélettes" and "Marnes à Cyrènes" is mirrored by an equally progressive increase of benthic Foraminifera. The most characteristic faunal elements are represented by small miliolids, Pararotalia canui (Plate 11, fig. 9), Buccella granulata (Plate 11, fig. 6) and some lagenids (Lagena spp., Lenticulina aff. $L$. reniformis). The small miliolids and Cancris turgidus (Plate 9, fig. 4) are however limited to the lower part of the "Marnes à Cyrènes".

At the drill site DP-202 the abundance and diversity steadily decreases towards the top of the unit, with the last two samples virtually devoid of Foraminifera. The middle "Marnes à Cyrènes" at the locality Allschwil-2 (sample A-23) display the highest diversity of 12 benthic species, including taxa, which are otherwise not present like Angulogerina spp., Lagena spp., Elphidiella minuta (Plate 11, fig. 10) and Pleurostomella alternans (Plate 8, fig. 16) (Text-figs. 4-7). The number of planktonic species ranges between 3 and 13, depending on the rate of reworking (see chapter 6).

\section{Palaeoenvironment}

In the lower part of the "Marnes à Cyrènes" conditions quite similar to the subsequent "Couches à Mélettes" prevailed. Abundant Aubignyna kiliani in addition to Pararotalia canui and Buccella granulata indicate shallower inner shelf or coastal habitats.

At the drill site DP-202 the decrease in Foraminifera taxa and the shallowing up coincide with the transition of ostracod assemblages. The middle part of the "Marnes à Cyrènes" at Allschwil-2 reflects a shortterm recurrence to deeper marine conditions. A slightly increased diversity and well-preserved specimens suggest a return to shallow marine conditions near the top of the unit.

\section{Palaeogeography}

The presented succession of palaeogeographic maps (Text-figs. 23-25) is based on the data published in BERger et al. (2005b), Picot et al. (2008) as well as field and literature data (mainly Roussé 2006). A more complete account may be found in the cited publications. Only the modified maps will be commented on here.

\section{Priabonian}

A single shallow marine Foraminifera fauna of Priabonian age (e.g., Turborotalia cocoaensis) was found by OHMERT (1993) in the drilling Bremgarten 1 between Freiburg i. Br. and Basel. Whether or not this occurrence relates to a short term Priabonian marine incursion as proposed by SissingH $(1998,2006)$ or to an enigmatic reworking event remains unresolved. 

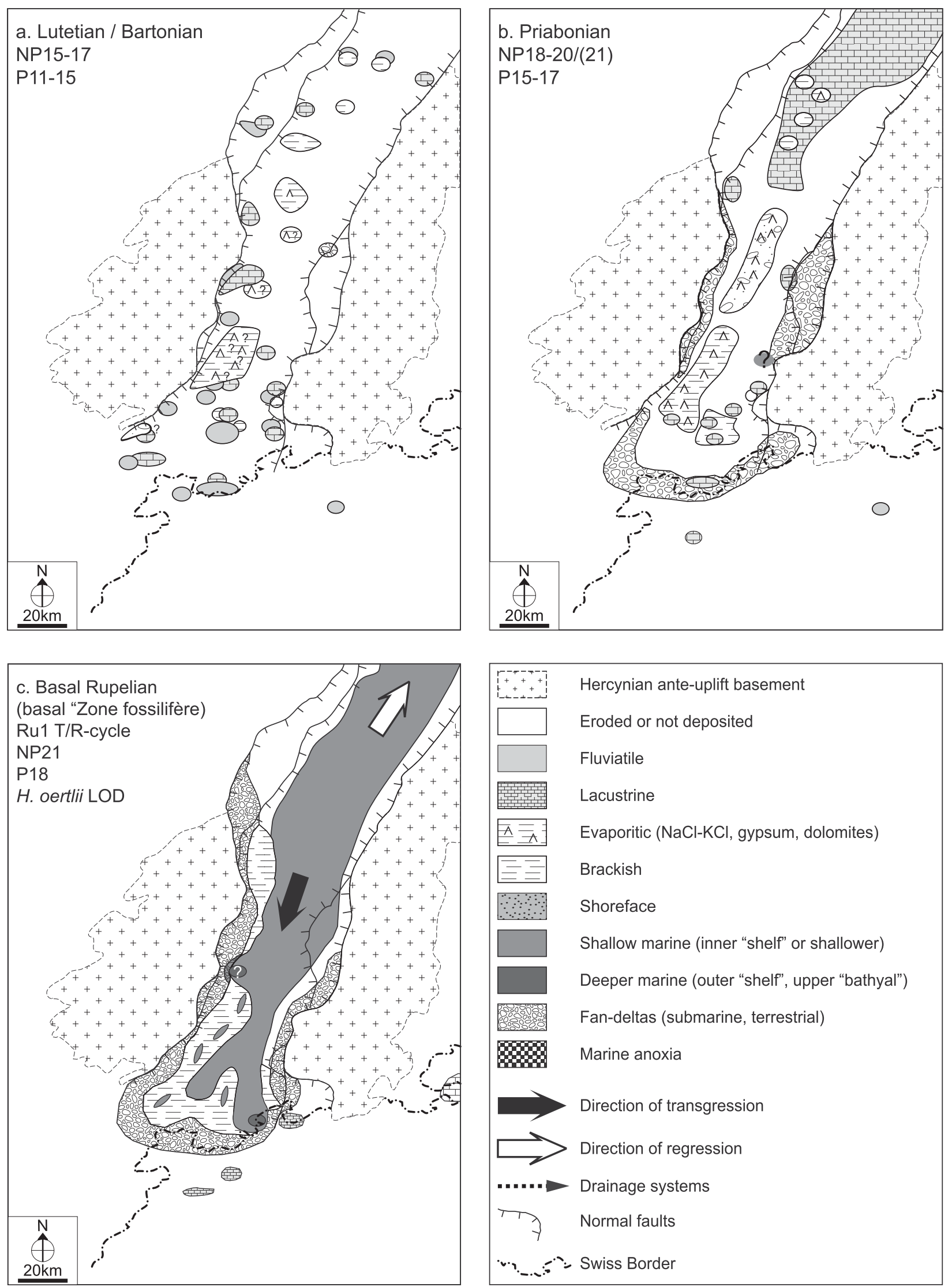

Compiled from Berger et al. (2005), Picot et al. (2008, acc.), PIRKEnseer (2007), Roussé (2006)

Text-fig. 23: Palaeogeographic maps of the southern Upper Rhine Graben and the alpine foreland from the Lutetian to the basal Rupelian. 

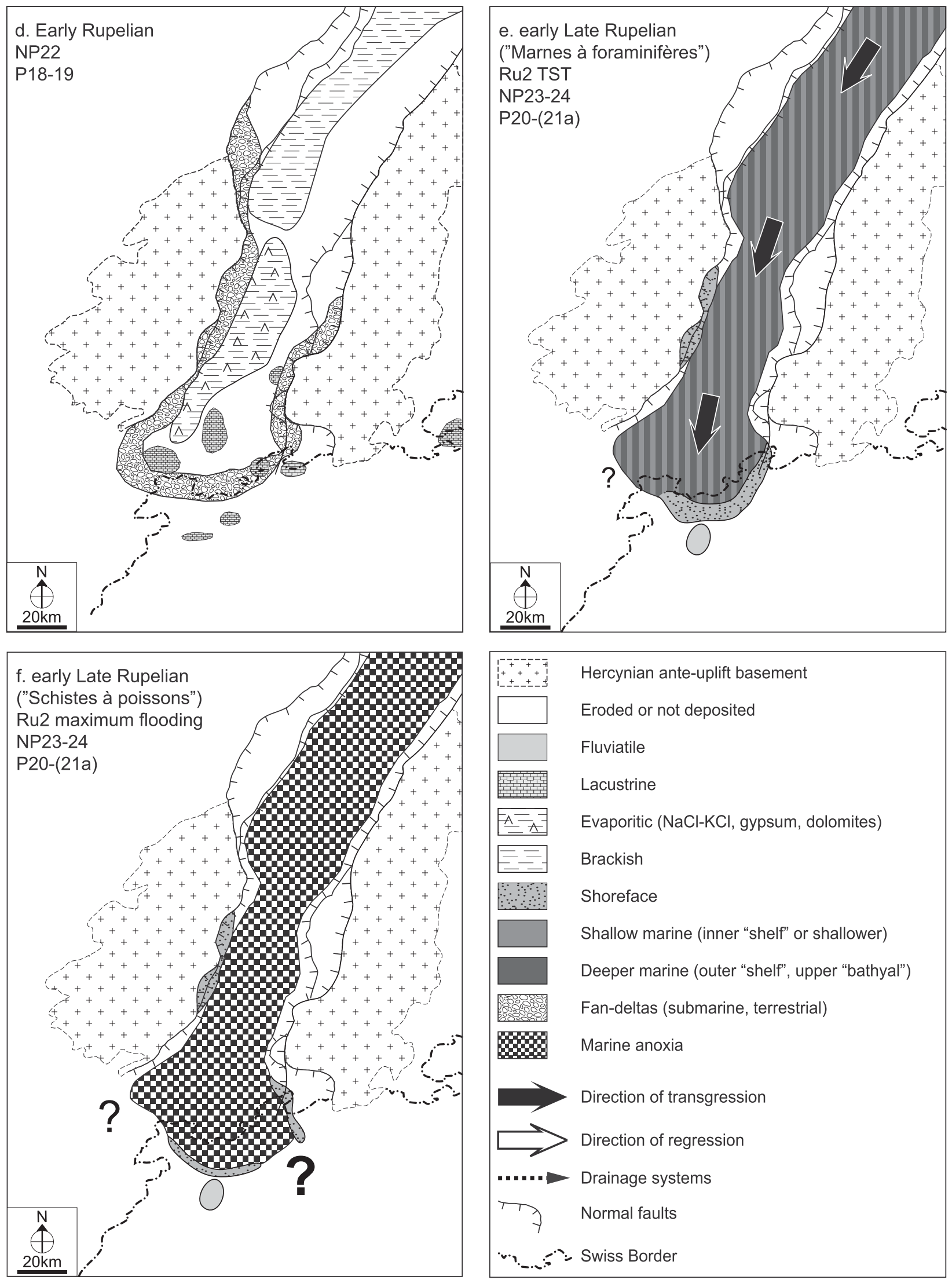

Compiled from Berger et al. (2005), Picot et al. (2008, acc.), Pirkenseer (2007), Roussé (2006)

Text-fig. 24: Palaeogeographic maps of the southern Upper Rhine Graben and the alpine foreland from the early Rupelian to the early Late Rupelian. 

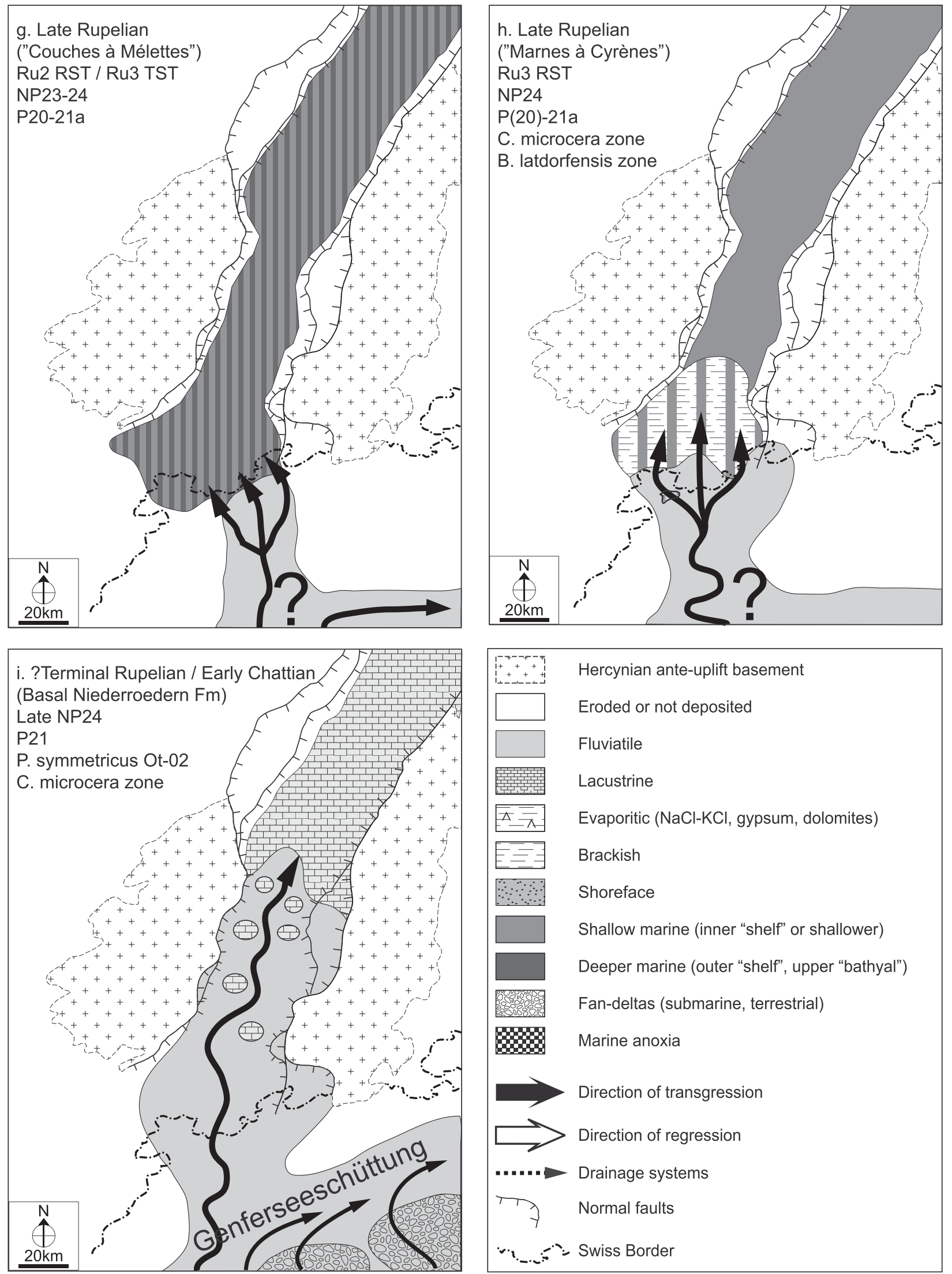

Compiled from Berger et al. (2005), Picot et al. (2008, acc.), Pirkenseer (2007), Roussé (2006)

Text-fig. 25: Palaeogeographic maps of the southern Upper Rhine Graben and the alpine foreland from the Late Rupelian to the basal Chattian. 


\section{Basal Rupelian}

The fully marine ostracod and foraminifer assemblages of the lower "Zone fossilifere" at the drill site Allschwil-2 indicate an ingression of the first Rupelian transgression as far south as Basel during the maximum flooding. The assemblages of Allschwil-2 and Strangenberg indicate deeper marine (outer shelf to upper bathyal zone) conditions.

$$
\text { Early ("Middle") Rupelian }
$$

The "Haustein" deposits of Allschwil-2 indicate lacustrine deposits in the area south of Basel.

Late Rupelian ("Couches à Mélettes", "Marnes à Cyrènes")

During the deposition of the "Couches à Mélettes" a deltaic system was established at the southern border of the research area and began to prograde northwards. This is evidenced by abundant fluviatile deposits south of the research area (BERGER et al. 2005b, Picot et al. 2008) and the presence of a deltaic (estuarine) facies architecture in the basin (Roussé 2006). The source of the corresponding drainage system was located within the already uplifted central and southwestern Helvetic realm. This is deduced due to the presence of abundant reworked Eocene planktonic Foraminifera in the Upper Rhine Graben. The main tributary may relate to a deviated pre-"Genferseeschüttung".

\section{Terminal Rupelian / Early Chattian}

Due to the biostratigraphic ages derived from planktonic Foraminifera (not younger than P21a) and otoliths (Palaeolebias symmetricus OT-02 zone) the onset of a predominantly fluviatile sedimentation possibly already started in the terminal Rupelian. Up to date no definite GSSP has been fixed for the Rupelian Chattian boundary, therefore the exact position remains uncertain. According to Roussé (2006) the fluviatile facies starts with a basin-wide erosional discordance.

\section{Summary}

The complete Paleogene succession of the Southern Upper Rhine Graben by means of two core drillings and several crucial outcrops has been studied. The results permit a confirmation and more complete perspective of the biodiversity as well as the palaeogeographic and palaeoenvironmental evolution of the Tertiary deposits in the area. The interpretative analyses are based on a systematic, possibly complete record of the occurring microfossil taxa. About 180 taxa of benthic and planktonic Foraminifera are documented from the Rupelian strata of the research area. Other faunal elements as Charophyta, otoliths, calcareous nannoplankton and Bolboforma complete the overall picture. While the Eocene remains enigmatic due to the scarcity of occurring fossil material, the two Rupelian transgression-regression cycles (Earliest Rupelian "Zone fossilifere", Late Rupelian "Série grise") of the Upper Rhine Graben are well traced by the microfossil assemblages.

Both transgressions start off with fully marine outer shelf to upper bathyal Foraminifera assemblages. In both cases the maximum flooding is achieved early in the sequence cycle. In the second Rupelian transgression the benthic and small sized planktonic Foraminifera associations indicate cold to temperate water. While generally well-oxygenated bottom waters and sediments prevailed during the initial phase ("Marnes à foraminiferes"), they abruptly changed to suboxic to anoxic conditions in the subsequent "Schistes à poissons". Nannofossils confirm fully marine conditions and suggest increased upwelling in this unit.

The corresponding/succeding regressive phase of the "Série grise" is characterised by a nearly complete absence of benthic Foraminifera in the "Couches à Mélettes". The gradual transition to the subsequent "Marnes à Cyrènes" is reflected by increase of diversity and abundance of benthic Foraminifera. While the "Marnes à Cyrènes" at the drill site Allschwil-2 show certain marine-brackish-freshwater fluctuations in their respective upper part, the transition from shallow marine to exclusively brackish conditions in the "Marnes à Cyrènes" (uppermost "Série grise") of the drilling DP-202 is rather short and abrupt.

Unfortunately no good planktonic Foraminifera index species are recorded from the research area. The data derived from assemblage ranges is distorted by the simultaneous occurrence of facultatively reworked Eo-Oligocene species and requires a conservative attribution to the Mid P20 to P21a plankton-zones for the "Série grise" deposits. The Age NP23-24 indicated by calcareous nannoplankton in the basal "Série grise" corresponds to other datings from the Upper Rhine Graben. Charophyte assemblages from the "Marnes à Cyrènes" and the lower part of the Niederroedern Formation suggest an attribution to the Late Rupelian to early Chattian Chara microcera - zone. A "Middle" Oligocene age is derived from a Bolboforma event in 
the middle "Marnes à Cyrènes" of the Allschwil-2 drill site. The occurrence of Palaeolebias symmetricus (OT02 zone) in the lithostratigraphically youngest sample from the Niederroedern Formation of the DP-202 drilling suggests a similar Late Rupelian to earliest Chattian age.

Abundant reworked Cretaceous (10 taxa) and Paleocene (1 species) to Eocene (20 taxa) planktonic Foraminifera occur in the Late Rupelian "Série grise". They are documented, figured and interpreted in relation to similar occurrences in the northern part of the Upper Rhine Graben and the Mainz Basin as well as possible source areas. The Lutetian is by far the most frequently represented stage. Abundant reworking starts in the Late Rupelian lower "Couches à Mélettes" and reaches its maximum in the increasingly clastic "Marnes à Cyrènes". Only rare occurrences are documented from the subsequent fluvio-lacustrine Niederroedern Formation.

Due to the absence of time-equivalent marine Eocene deposits in the Upper Rhine Graben itself the planktonic Foraminifera are supposed to be reworked and derived from the alpine domain. This supports the proposition of a vast northwards prograding deltasystem that was located close to the southern margin of the research area (Roussé 2006). The presence of the reworked planktonic Foraminifera confirms a considerable uplift of Cretaceous and Eocene sediments within the central and / or southwestern Swiss Alpine realm already by the Late Rupelian. Furthermore sedimentary overfill of the western Swiss Molasse Basin must have already begun, leading to the northward deviation of the axial drainage system of the Swiss Molasse Basin ("pre-Genferseeschüttung").

\section{Acknowledgements}

We thank the Museum of Natural History of Basel for leaving us the samples of the drilling Allschwil-2 for examination.

Stéphane Roussé (Université Louis Pasteur, Strasbourg) guided the initial introduction to several outcrops of the Southern Upper Rhine Graben. He arranged the sampling of the DP-202 core, sent us some samples of the Retzwiller outcrop and furnished us also with his sedimentological core and outcrop logs.

Fred Rögl (Vienna, Austria) was a great help solving taxonomical issues concerning several benthic Foraminifera species and provided access to literature. Michèle Caron (Fribourg) determined the reworked Cretaceous Foraminifera taxa. Stjepan Coric (Geologische Bundesanstalt, Vienna) determined the calcareous nannoplankton and helped out with literature. Hermann Fischer provided additional information on the Allschwil-2 core.
Without the extensive introduction to and the successive adjustments of the scanning electron microscope by Christoph Neururer (University of Fribourg, Switzerland) the elaboration of the Plate quantity and quality would not have been possible. Richard Waite (university of Fribourg, Switzerland) was in charge of proof-reading the manuscript.

This study is based on the PhD-thesis Pirkenseer (2007). The latter was founded by the Swiss National Science Foundation (project numbers 200020-109457 and 2000-066935).

\section{References}

Andreae, A. (1884): Ein Beitrag zur Kenntnis des Elsässer Tertiärs. - Abh. geol. Spezialk. Elsass-Lothringen 2 (3) (atlas): 12 Plates.

Andreae, A. (1894): Die Foraminiferenfauna im Septarienton von Frankfurt a.M. - Ber. Senckenberg. Naturforsch. Ges. 1894: 43-51.

BAtjes, D.A.J. (1958): Foraminifera of the Oligocene of Belgium. - Mém. Inst. Roy. Sci. Nat. Belg. 143: 3-188.

BERGER, J.-P. (1995): Des nannofossiles calcaires aux rhinoceros: déplacés our remaniés? - Eclogae geologicae Helvetiae 85 (3): 657-680.

Berger, J.-P., Reichenbacher, B., Becker, D. et al. (2005a): Paleogeography of the Upper Rhine Graben (URG) and the Swiss Molasse Basin (SMB) from Eocene to Pliocene. - Int. J. Earth Sci. 94 (4): 697-710.

Berger, J.-P., Reichenbacher, B., Becker, D. et al. (2005b): Eocene-Pliocene time scale and stratigraphy of the Upper Rhine Graben (URG) and the Swiss Molasse Basin (SMB). - Int. J. Earth Sci. 94 (4): 711-731.

Berggren, W.A., Pearson, P.N., Huber B.T. et al. (2006): Taxonomy, biostratigraphy and phylogeny of Eocene Acarinina. - Cushman Found. Spec. Publ. 41: 257-326.

Bitterli-Brunner, P. \& Fischer, H. (1988): Erläuterungen zum Blatt 1067 Arlesheim. - Geol. Atlas .Schweiz 1:25000, Atlasbl. 80: 1-65.

BLow, W.H. (1959): Age, correlation and biostratigraphy of the Upper Tocuyo (San Lorenzo) and Pozón Formations, eastern Falcón, Venezuela. - Bull. Amer. Paleontol. 38: 59-251.

Blow, W.H. (1969): Late Middle Eocene to Recent planktonic foraminiferal biostratigraphy. - In: BRÖNNIMANN, P. \& Renz, H.H. (eds.): Proceedings of the First International Conference on Planktonic Microfossils. - E.J. Brill, Leiden 1: $199-422$.

BLow, W.H. (1979): The Cainozoic Globigerinida. - E.J. Brill, Leiden, $113 \mathrm{p}$.

Blow, W.H. \& BAnner, F.T. (1962): The Mid-Tertiary (Upper Eocene to Aquitanian) Globigerinacea. - In: EAmEs, F.T. et al. (eds.): Fundamentals of Mid-Tertiary stratigraphical correlation. - Cambridge Univ. Press, 61-151.

Bolli, H.M. (1954): Note on Globigerina concinna Reuss 1850. - Contr. Cushman Lab. Foramin. Res. 5: 1-3.

Bolli, H.M. (1957a): Planktonic Foraminifera from the Eocene Navet and San Fernando formations of Trinidad, B.W.I. In: Loeblich, A.R. Jr. and coll.: Studies in Foraminifera. - U.S. Nat. Mus. Bull. 215: 155-172. 
Bolli, H.M. (1957b): Planktonic foraminifera from the Oligocene - Miocene Cipero and Lengua formations of Trinidad, B.W.I. - In: Loeblich, A.R., Jr. and coll.: Studies in Foraminifera. - U.S. Nat. Mus. Bull. 215: 97-124.

Bolli, H.M., Loeblich, A.R. Jr. \& Tappan, H. (1957): Planktonic foraminiferal families Hantkeninidae, Orbulinidae, Globorotaliidae, and Globotruncanidae. - In: LoeBLICH, A.R. Jr. and coll.: Studies in Foraminifera. - U.S. Nat. Mus. Bull. 215: 3-50.

Borsetti, A.M. (1959): Tre nuovi foraminiferi planctonici dell'Oligocene piacentino. - Gior. Geol. 27: 205-212.

BRADY, H.B. (1881): Notes on some of the reticularian Rhizopoda of the "Challenger" expedition. - Quart. J. Microscop. Sci., new ser. 21: 1-41.

Caron, M. (1985): Cretaceous planktic foraminifera. - In: Bolli, H.M., Saunders, J.B. \& Perch-Nielsen, K. (eds.): Plankton stratigraphy. - Cambridge Earth Sci. Ser.: 17-86.

CARPEnTER, W.B. (1875): The microscope and its revelations. - Lindsay $\&$ Blakiston, $5^{\text {th }}$ edition, 848 p.

Carsey, D.O. (1926): Foraminifera of the Cretaceous of central Texas. - Univ. Texas Bull. 2612: 1-56.

Cicha, I., Rögl, F., Rupp, C. et al. (1998): Oligocene-Miocene Foraminifera of the Central Paratethys. - Abh. Senckenberg. Naturforsch. Ges. 549: 325 p.

Cole, W.S. (1927): A foraminifal fauna from the Guayabal Formation in Mexico. - Bull. Amer. Paleontol. 14: 1-46.

Cushman, J.A. (1923): The Foraminifera of the Vicksburg Group. - U.S. Geol. Surv. Prof. Pap. 133: 11-71.

Cushman, J.A. (1926): Some Foraminifera from the Mendez Shale of eastern Mexico. - Contr. Cushman Lab. Foramin. Res. 2: 16-24.

Cushman, J.A. (1928): Additional foraminifera from the Upper Eocene of Alabama. - Contr. Cushman Lab. Foramin. Res. 4: 73-79.

Cushman, J.A. (1932): Textularia and related forms from the Cretaceous. - Contr. Cushman Lab. Foramin. Res. 8: 86-97.

Cushman, J.A. (1936): New genera and species of the families Verneuilinidae and Valvulinidae and of the subfamily Virgulininae. - Spec. Publ. Cushman Lab. Foramin. Res. 6: $1-71$.

Cushman, J.A. (1940): Midway Foraminifera from Alabama. - Contr. Cushman Lab. Foramin. Res. 16: 51-73.

Cushman, J.A. \& Bermúdez, P.J. (1937): Further new species from the Eocene of Cuba. - Contr. Cushman Lab. Foramin. Res. 13: 1-29.

Cushman, J.A. \& Edwards, P.G. (1938): Notes on the Oligocene species of Uvigerina and Angulogerina. - Contr. Cushman Lab. Foramin. Res. 14: 79-84.

Cushman, J.A. \& Ellisor, A.C. (1931): Some New Tertiary Foraminifera from Texas. - Contr. Cushman Lab. Foramin. Res. 7: 51-59.

Cushman, J.A. \& Jarvis, P.W. (1929): New foraminifera from Trinidad. - Contr. Cushman Lab. Foramin. Res. 5: 6-17

Cushman, J.A. \& Parker, F.L. (1937): Notes on some European Eocene species of Bulimina. - Contr. Cushman Lab. Foramin. Res. 13: 46-54.
Cushman, J.A. \& Ponton, G.M. (1932): An Eocene foraminiferal fauna of Wilcox age from Alabama. - Contr. Cushman Lab. Foramin. Res. 8: 51-72.

Cushman, J.A. \& TodD, R. (1942): The genus Cancris and its species. - Contr. Cushman Lab. Foramin. Res. 18: 72-94.

Cuvillier, J. \& SzaKall, V. (1949): Foraminiferes d'Aquitaine. Première Partie (Reophacidae à Nonionidae). - Soc. Nat. Pétroles d'Aquitaine, F. Boisseau, 112 p.

Dercourt, J. et al. (eds.) (2000): Atlas Peri-Tethys, Palaeogeographical maps. - CCGM/CGMW, 24 maps, explanatory notes, $269 \mathrm{p}$.

Doebl, F. (1962): Tertiär des Rheintalgrabens - Taxionomie: Foraminifera. - Leitfossilien der Mikropaläontologie (Arbeitskreis deutscher Mikropaläontologen, eds.): 385-391.

Doebl, F. \& Sonne, V. (1974): Mikrofauna und -flora des Unteren Meeressandes (Rupel) 1. Sandgrube am Steigerberg bei Wendelsheim (Mainzer Becken) b. Foraminiferen und Nannoplankton. - Mainzer geowiss. Mitt. 3: 13-67.

DE Montfort, D. (1808): Conchybiologie systématique et classification méthodique des coquilles. - F. Schoell, tome 1: $409 \mathrm{p}$.

D'Orbigny, A. (1826): Tableau méthodique de la classe des cephalopods. - Ann. Sci. Nat. 1 (7): 245-314.

D'Orbigny, A. (1839): Voyage dans l'Amérique méridionale, 5: Foraminiferes. - P. Bertrand, 1-86.

D'Orbigny, A. (1839): Foraminifères. - In: DE LA SAGRA, R.: Histoire physique, politique et naturelle de l'Ile de Cuba, $224 \mathrm{p}$.

D'Orbigny, A. (1846): Die fossilen Foraminiferen des tertiären Beckens von Wien. - Gide et Comp., 312 p.

D'Orbigny, A. (1852): Prodrome de la paléontologie stratigraphique universelle des animaux mollusques et rayonnes faisant suite au cours élémentaire de paléontologie et de géologie stratigraphique. - Victor Masson, 189 p.

De Pietri, V.L., Berger, J.-P., Pirkenseer, C., Scherler, L. \& MAYR, G. (2010, proof): New skeleton from the early Oligocene of Germany indicates a stem-group position of diomedeoidid birds. - Acta Palaeontologica Polonica 55 (1): 23-34.

Duringer, P. (1988): Les conglomérats des bordures du rift cénozoique rhénan. Dynamique sédimentaire et contrôle climatique. - Univ. Louis Pasteur, PhD thesis, 278 p.

Earland, A. (1933): Foraminifera. Part II. South Georgia. Discovery Rep. 7: 27-138.

ECKERT, H.R. (1963): Die obereozänen Globigerinen-Schiefer (Stad- und Schimbergschiefer) zwischen Pilatus und Schrattenfluh. - Eclogae geologicae Helvetiae 56 (2): 10021072.

EhrenberG, C.G. (1840): Über die Bildung der Kreidefelsen und des Kreidemergels durch unsichtbare Organismen. Phys. Abh. Königl. Akad. Wiss. Berlin 1838: 59-147.

Finlay, H.J. (1939): New Zealand foraminifera: Key species in stratigraphy - No.2. - Roy. Soc. New Zeal., Trans. Proc. 69: 89-128.

FInLAY, H.J. (1947): New Zealand foraminifera: Key species in stratigraphy - No.5. - New Zeal. J. Sci. and Technol. 28: 259-292. 
Fischer, H. (1965a): Geologie des Gebietes zwischen Blauen und Pfirter Jura. - Beitr. geol. Karte Schweiz, NF 122: 106 p.

Fischer, H. (1965b): Oberes Rupélien (Septarienton) des südlichen Rheintalgrabens: Tongrube Allschwil bei Basel. Bull. Verein. Schweizer Petroleum-Geologen und -Ingenieure 31 (81): 7-16.

Fischer, H., Hauber, L. \& Wittmann, O. (1971): Erläuterungen zum Blatt 1047 Basel. - Geol. Atlas Schweiz 1:25000, Atlasbl. 59: 1-55.

Friese, H. (1951): Zur Foraminiferen-Fauna der Meeresmolasse des unteren Inngebietes. - Abh. Geol. Dienstes Berlin 227: $1-52$.

Gradstein, F.M., Ogg, J.G. \& Smith, A.G. (eds.) (2004): A geologic time scale. - Cambridge Univ. Press, 610 p.

Gramann, F. (1965): Bolivina (Brizalina) beyrichi (Reuss) und verwandte Foraminiferen aus dem deutschen Oligozän. - Geol. Jahrb. 82: 437-466.

GRIMM, K.I. (1993): Spiroplectinella KISEL'MAN 1972 (Foraminifera) aus dem Rupelium (Oligozän) des Maainzer Beckens. - Paläontol. Z. 67 (1/2): 21-26.

GRIMM, K.I. (1994): Paläoökologie, Paläogeographie und Stratigraphie im Mainzer Becken, im Oberrheingraben, in der Hessischen Senke und in der Leipziger Bucht während des Mittleren Rupeltons (Fischschiefer / Rupelium / Unteroligozän). - Mitt. Pollichia 81: 7-193.

GRIMM, K.I. (1998): Correlation of Rupelian coastal and basin facies in the Mainz Basin (Oligocene, Germany). - N. Jahrb. Geol. und Paläontol. 1998/3: 146-156.

GrImM, K.I. (2002): Foraminiferal zonation of early Oligocene deposits (Selztal Group, Latdorfian, Rupelian) in the Mainz Basin, Germany. - J. Micropalaeontol. 21: 67-74.

Grimm, K.I., Köthe, A. \& Grimm, M. (2005): Sedimentologie und Biostratigraphie im Rupelium der Ziegeleigrube Jungk, Wöllstein (Mainzer Becken). - Senckenbergiana lethaea 85 (2): 231-259.

Grimm, K.I. \& Steurbaut, E. (2001): Foraminiferal biofacies analyses of the Boom Clay Formation in the Rupel area (Oligocene, Belgium) and correlation with the Mainz Basin (Germany). - Aardkund. Mededel. 11: 9-20.

Grzybowski, J. (1896): Otwornice czerwonych ilów z Wadowic. - Rozprawy Akad. Umiejetnosci w Krakowie, Wydziat Matematyczno-Przyrodniczy serya 30: 261-308.

GrZybowsKi, J. (1898): Otwornice pokladów naftonosnych okolicy Krosna. - Rozprawy Akad. Umiejetnosci w Krakowie, Wydzial Matematyczno-Przyrodniczego 33: 257-305.

GüMBEL, C.W. (1868): Beiträge zur Foraminiferenfauna der nordalpinen, älteren Eocängebilde oder der Kressenberger Nummulitenschichten. - Abh. Königl. Bay. Akad. Wiss. II 10: 579-730.

Hagn, H. (1952). Foraminiferen der subalpinen Molasse. - In: HaGn, H. \& HölzL, O.: Geologisch-paläontologische Untersuchungen in der subalpinen Molasse des östlichen Oberbayerns zwischen Prien und Sur mit Berücksichtigung des im Süden anschlieflenden Helvetikums. - Geologica bavarica 10: 1-208.
Hantken, M. (1871): Az esztergomi barnaszénterület földtani viszonyai (Die geologischen Verhältnisse des Graner Braunkohlegebiets). - Königl. ungar. geol. Anst. Mitt. Jahrb. 1: $1-141$.

Hantken, M. (1875): Die Fauna der Clavulina szaboi-Schichten. I. Foraminiferen. - Mitt. Jahresber. königl. ungar. geol. Anst. 4: 1-93.

Hardenbol, J., Tierry, J., Farley, M.B. et al. (1998): Mesozoic and Cenozoic sequence chronostratigraphic framework of European basins. - In: DE GRACIANSKY, P.C., Hardenbol, J., Jaceuin, T. et al. (eds.): Mesozoic and Cenozoic sequence stratigraphy of European basins. SEPM Spec. Pub. 60: 3-13.

Hasemann, W. \& Heinemann, W. (1957): Mittel- und Oberoligozän (Rupelien und Chattien) an der Ostseite des Kaiserstuhls. - Mitt. bad. Landesver. Naturk. und Natursch. NF 7 (1): 1-5.

Hedberg, H.D. (1937): Foraminifera of the Middle Tertiary Carapita Formation of northeastern Venezuela. - J. Paleontol. 11: 661-697.

Herb, R. (1988): Eocaene Paläogeographie und Paläotektinik des Helvetikums. - Eclogae geologicae Helvetiae 81 (3): 611-657.

Hess, H. \& WeIleR, W. (1955): Untersuchungen an Fischen aus dem Alttertiär der Umgebung von Basel. - Eclogae geologicae Helvetiae 48 (2): 427-447.

Hofmann, G.W. (1967): Untersuchungen an der Gattung Bolivina (Foraminifera) im Oligozän und Miozän der ostbayerischen Molasse. - Geologica Bavarica 57: 121-204.

Hornibrook, N. de B. (1965): A preliminary statement on the types of the New Zealand Tertiary Foraminifera described in the reports of the Novara expedition in 1865. - New Zeal. J. Geol. and Geophys. 8: 530-536.

Huber, B. (1994): Rupelian foraminifera in the southern Rhinegraben and their paleoecological significance. - PhD Thesis, Univ. Basel, $92 \mathrm{p}$.

Huber, B.T., Olsson, R.K. \& Pearson, P.N. (2006): Taxonomy, biostratigraphy, and phylogeny of Eocene microperforate planktonic Foraminifera (Jenkinsina, Cassigerina, Tenuitella, and Cassigerinella) and problematica (Dipsidripella). - In: Pearson, P.N., Olsson, R.K., Huber, B.T. et al. (eds.): Atlas of Eocene planktonic Foraminifera. - Cushman Found. Spec. Publ. 41: 461-508.

Jenkins, D.G. (1966): Planktonic foraminiferal zones and new taxa from the Danian to Lower Miocene of New Zealand. - New Zeal. J. Geol. and Geophys. 8: 1088-1126.

Jenkins, D.G. (1985): Southern mid-latitude paleocene to Holocene planktic Foraminifera. - In: Bolli, H.M., Saunders, J.B. \& Perch-Nielsen, K. (eds.): Plankton stratigraphy. - Cambridge Earth Sci. Ser.: 263-282.

Jenkins, D.G. \& ORR, W.N. (1973): Globigerina utilisindex n. sp. from the Upper Eocene-Oligocene of the eastern equatorial Pacific. - J. Foramin. Res. 3: 133-135.

Jones, R.W. \& CHARnock, M.A. (1985): „Morphogroups“ of agglutinated Foraminifera, their life positions and feeding habits and potential applicability in (paleo)ecological studies. - Rev. Paléobiol. 4 (2): 311-320. 
Jones, T.R. \& PARker, W.K. (1860): On the rhizopodal fauna of the Mediterranean, compared with that of the Italian and some other Tertiary deposits. - Quart. J. Geol. Soc. 16: 292-307.

Kaminski, M.A. \& Gradstein, F.M. (2005): Atlas of Paleogene cosmopolitan deep-water agglutinated Foraminifera. Grzybowski Found. spec. publ. 10: 547 p.

KARrer, F. (1867): Zur Foraminiferenfauna in Oesterreich. Sitzungsber. Kaiserl. Akad. Wiss. Wien, Math.-Naturwiss. Cl. 55: 357-368.

Keijzer, F.G. (1945): Outline of the eastern part of the province of Oriente, Cuba. - Publ. en uit het Mineral.-Geol. Insti. Rijksuniv. Utrecht, Physiograph.-Geol. Reeks II 6: $1-216$.

Kempf, O. \& Pfiffner, O.A. (2004): Early Tertiary evolution of the North Alpine Foreland Basin of the Swiss Alps and adjoining areas. - Basin Res. 16 (4): 549-567.

Kiesel, Y. (1970): Die Foraminiferenfauna der paläozänen und eozänen Schichtenfolge der Deutschen Demokratischen Republik. - Paläontol. Abh. Abt. A 4: 163-394.

LI, J. (2003): Neogene calcareous nannofossil biostratigraphy and the Coccolithus pelagicus abundance of ODP Leg 186 cores from the Japan Trench. - Proc. Ocean Drilling Progr., sci. res. 186: 1-31 (online).

LiHou, J.C. (1995): A new look at the Blattengrat unit of eastern Switzerland: Early Tertiary foreland basin sediments from the South Helevetic realm. - Eclogae geologicae Helvetiae 88 (1): 91-114.

Luckzkowska, E. (1974): Miliolidae (Foraminiferida) from the Miocene of Poland (part 2). - Acta Palaeontologica Polonica 19: 3-176.

Martin, L.T. (1943): Eocene foraminifera from the Type Lodo Fm., Fresno County, California. - Stanford Univ. Publ., Univ. Ser., Geol. Sci. 3: 93-125.

Mehrnusch, M. (2000): Bolivina beyrichi Reuss (Foraminifera), eine heteromorphe Art aus dem deutschen Tertiär. Jahresber. und Mitt. oberrhein. geol. Vereins NF 82: 223-233.

Melinte, M.C. (2005): Oligocene palaeoenvironmental changes in the Romanian Carpathians, revealed by calcareous nannofossils. - Studia Geologica Polonica 124: 341-352.

Menkveld-Gfeller, U. (1995): Stratigraphie, Fazies und Palaeogeographie des Eocaens der helvetischen Decken der Westschweiz (Diablerets- und Wildhorn-Decke). - Eclogae geologicae Helvetiae 88 (1): 115-134.

Meulenkamp, J.E., Sissingh, W., Londeix, L. et al. (2000): Late Rupelian (32-29 Ma). - In: Craseuin, S. (ed.): Atlas Peri-Tethys. - Palaeogeographical maps, explanatory notes: 171-178.

Mödden, C., Schäfer, P., Reichenbacher, B. et al. (2000): Säugetiere, Fisch-Otolithen, Ostracoden, Mollusken und Charophyten aus den Süßwasser-Schichten (Oligozän) von Wolfsheim im Mainzer Becken. - Paläontol. Z. 74 (3): 343-361.

Montagu, G. (1803): Testacea Britanica or natural history of British shells, marine, land and fresh-water, part 3. - J.S. Hollis, 606 p.
Morozova, V.G. (1939): Nadsemeistvo foraminifer Globigerinidea superfam. nova I nekotori yevo predstaviteli. Dok. Akad. Nauk SSSR 114: 1109-1111.

Neal, J.E. \& Hardenbol, J. (1998): Introduction to the Paleogene. - In: de Graciansky, P.C., Hardebol, J., Jaquin, T. et al. (eds.): Mesozoic and Cenozoic sequence stratigraphy of European basins. - SEPM Spec. Publ. 60: 87-90.

OHMERT, W. (1993): Eine obereozäne Foraminiferenfauna aus dem südlichen Oberrhein-Graben. - Zitteliana 20: $323-329$.

PAPp, A. (1975): Die Entwicklung der Uvigerinen in der Puchkirchener Schichtengruppe. - In: Chronostratigraphie und Neostratotypen V, Miozän OM Egerien: 279-287.

PApp, A. \& Schmid, M.E. (1985): Die fossilen Foraminiferen des tertiären Beckens von Wien: Revision der Monographie von Alcide d'Orbigny (1846). - Abh. Geol. Bundesanst. 37: 2-311.

Pessagno, E.A. (1967): Upper Cretaceous planktonic Foraminifera from the western Gulf Coastal Plain. - Palaeontographica Americana 5: 243-445.

Pharisat, A. (1991): La paléoichthyofaune du Rupélien marin de Froidefontaine - Partie $1 \&$ 2. - PhD Thesis, Univ. Franche-Comté, 607p. +47 p. (annex).

Picot, L., Becker, D., Cavin, L. et al. (2008): Sédimentologie et paléontologie (foraminifères, ostracodes, poissons) des paléoenvironnements côtiers des dépôts de l'UMM rhénane dans le Jura suisse. - Swiss J. Geosci. 101 (2): 483-513.

Pirkenseer, C. (2007): Foraminifera, Ostracoda and other microfossils of the Southern Upper Rhine Graben - Palaeoecology, biostratigraphy, palaeogeography and geodynamic implications. - PhD Thesis, Univ. Fribourg, Switzerland, $340 \mathrm{p}$.

Plummer, H.J. (1931): Some Cretaceous Foraminifera in Texas. - Univ. Texas Bull. 3101: 109-203.

Premoli Silva, I., Rettori, R. \& Verga, D. (2003): Practical manual of Paleocene and Eocene planktonic Foraminifera. - Int. School planktonic Foramin, $2^{\circ}$ Course, Tipografia Pontefelcino, Perugia, $152 \mathrm{p}$.

Premoli Silva, I. \& Verga, D. (2004): Practical manual of Cretaceous planktonic Foraminifera. - Int. School on planktonic Foramin. $1^{\circ}$ Course, Tipografia Pontefelcino, Perugia, 283 p.

Radtke, G., Griessemer, T. W., Grimm, K. I. et al. (2006): Erster Meereseinbruch im Oberrheingraben - Entwicklung, Biodiversität, Paläogeographie (Pechelbronn-Gruppe, Obereozän - Unteroligozän) - Ausgewählte Fossilgruppen. - Poster Molasse Meeting 2006, Geneva.

Reichenbacher, B. (2000): Das brackisch-lakustrine Oligozän und Unter-Miozän im Mainzer Becken und Hanauer Becken: Fischfaunen, Paläoökologie, Biostratigraphie, Paläogeographie. - Courier Forschungs-Inst Senckenberg 222: 1-143.

Reichenbacher, B., Berger, J.-P. \& Weidmann, M. (1996): Charophytes et otolithes de la Molasse d'eau douce inférieur oligocène de Moutier (Jura suisse). - N. Jahrb. Geol. und Paläontol. 202 (1): 63-93. 
Reichenbacher, B. \& Weidmann, M. (1992): Fisch-Otolithen aus der oligo-/miozänen Molasse der West-Schweiz und der Haute Savoie (Frankreich). - Stutt. Beitr. Naturk. B 184: 1-83.

Reiser, H. (1987): Die Foraminiferen der bayerischen Oligozän-Molasse. Systematik, Stratigraphie und Paläobathymetrie. - Zitteliana 16: 3-131.

Reuss, H. (1851): Über die fossilen Foraminiferen und Entomostraceen der Septarienthone der Umgegend von Berlin. - Z. dt. Geol. Ges. 3: 49-92.

Reuss, H. (1852): Über Foraminiferen aus verschiedenen Septarienthonen (briefliche Mitteilung). - Z. dt. Geol. Ges. 4: 16-19.

Reuss, A.E. (1856): Beiträge zur Charakteristik der Tertiärschichten des nördlichen und mittleren Deutschlands. Sitzungsber. Kaiserl. Akad. Wiss. Wien, Math.-Naturwiss. Cl. 18 (1855): 197-273.

Reuss, A.E. (1863): Beiträge zur Kenntnis der tertiären Foraminiferenfauna. (Zweite Folge). - Sitzungsber. Kaiserl. Akad. Wiss. Wien.,Math.-Naturwiss. Cl. 48: 1-8.

Reuss, A.E. (1865): Zur Fauna des deutschen Oberoligozäns. Sitzungsber. Kaiserl. Akad. Wiss. Wien, Math.-Naturwiss. Cl. 50 (1864): 1-48.

Reuss, A.E. (1866): Die Foraminiferen, Anthozoen und Bryozoen des deutschen Septarienthones. Ein Beitrag zur Fauna der mitteloligozänen Tertiärschichten. - Denkschr. Kaiserl. Akad. Wiss. Mathe.-Naturwiss. Cl. 25: 117-214.

Reuss, A.E. (1870): Die Foraminiferen des Septarienthones von Pietzpuhl. - Sitzungsber. Kaiserl. Akad. Wiss. Wien, Math.-Naturwiss. Cl. 62: 1-39.

RöGL, F. (1998): Foraminiferenfauna aus dem Karpat (UnterMiozän) des Korneuburger Beckens. - Beitr. Paläontol. 23: 123-173.

RögL, F. \& Spezzaferri, S. (2003): Foraminiferal paleoecology and biostratigraphy of the Mühlbach section (Gaindorf Formation, Lower Badenian), Lower Austria. - Ann. Naturhist. Mus. Wien 104 A: 23-75.

Roemer, F.A. (1838): Die Cephalopoden des norddeutschen tertiären Meeressandes. - N. Jahrb. Mineral., Geogr., Geol. und Petrefakten-Kunde 1838: 381-395.

Roetzel, R., Coric, S., Galovic, I. et al. (2006): Early Miocene (Ottnangian) coastal upwelling conditions along the southeastern scarp of the Bohemian Massif (Parisdorf, Lower Austria, Central Paratethys). - Beitr. Paläontol. 30: $387-413$.

Roussé, S. (2006): Architecture et dynamique des séries marines et continentales de l'Oligocène Moyen et Supérieur du Sud du Fossé Rhénan: Evolution des milieux de dépôt en contexte de rift en marge de l'avant-pays alpin. - PhD Thesis, Univ. Louis Pasteur, Strasbourg, $471 \mathrm{p}$.

SAcco, F. (1893): Le bathysiphon à l'etat fossile. - Bull. Soc. Géol. France 3 (21): 165-169.

SARS, G.O (1872): Undersøgelser over Hardangerfjordens fauna. - Forhandlinger i Videnskabsselskabet i Kristiania 1871: 246-286.

SCHÄFER, P. (2000): Zur Stratigraphie und Genese der tertiären Sedimente zwischen Eisenberg und Lautersheim im süd- westlichsten Teil des Mainzer Beckens. - Jahresber. und Mitt. oberrhein. geol. Ver. NF 82: 175-222.

SChäfer, P. \& KUHN, W. (2004): Mikropaläontologische und lithologische Abgrenzungskriterien zwischen Oberem Rupelton [= Rosenberg-Subformation] und "Schleichsand“ [= Stadecken-Formation] im Rupelium (Tertiär) des Mainzer Beckens. -Mainzer geowiss. Mitt. 32: 139-178.

SCHERER, F. (1966): Geologisch-palaeontologische Untersuchungen im Flysch und in der Molasse zwischen Thunersee und Eriz (Kt. Bern). - Beitr. geol. Karte Schweiz 127: $1-115$.

SCHERLER, L. (2005): Istein, Rheinweiler, Guewenheim: Trois coupes du Paléogène rhénan. + Cartographie des formations superficielles du versant de la Montagne de Boudry (Neuchâtel, Suisse). - Diploma Thesis, Univ. Neuchâtel, $109 \mathrm{p}$.

Schrodt, F. (1894): Das Vorkommen der Foraminiferen-Gattung Cyclammina im Oberen Jura. - Z. Dt. Geol. Ges. 1893 (45): 733-735.

SCHULER, M. (1990): Environments et paléoclimats paléogènes. Palynologie et biostratigraphie del 'Éocène et del'Oligocène inférieur dans les fosses rhénans et de Hesse. - Doc. B.R.G.M. 190: 503 p.

SCHWAger, C. (1866): Fossile Foraminiferen von Kar-Nicobar: Reise der österreichischen Fregatte Novara um die Erde in Jahren 1857, 1858, 1859. - Geol. Theil 2: 187-268.

Seguenza, G. (1862): Dei terreni Terziarii del distretto di Messina; Parte II - Descr. foraminiferi monotalmici delle marne mioceniche del distretto di Messina. - T. Capra Messina, $84 \mathrm{p}$.

Shutskaya, E.K. (1958) [Russian]: Variabilité de quelques foraminifères planctoniques du Paléogène inférieur du Caucase septentrional. - Voprosy Mikropaleontol. Akad. Nauk SSSR 2: 84-90.

SigAL, J. (1948): Notes sur les genres de foraminifères Rotalipora Brotzen, 1942 et Thalmanninella, famille des Globorotaliidae. - Rév. Inst. franç. Pétrole 3: 95-103.

SinclaIR, H.D. (1996): Plan-view curvature of foreland basins and its implications for the palaeostrength of the lithosphere underlying the western Alps. - Basin Res. 8 (2): 173-182.

SissingH, W. (1998): Comparative Tertiary stratigraphy of the Rhine Graben, Bresse Graben and Molasse Basin: correlation of Alpine foreland events. - Tectonophysics 300: 249-284.

SissingH, W. (2003): Tertiary paleogeographic and tectonostratigraphic evolution of the Rhenish Triple Junction. Palaeogeogr., Palaeoclimatol., Palaeoecol. 196 (1-2): 229-263.

SissingH, W. (2006): Kinematic sequence stratigraphy of the European Cenozoic Rift System and Alpine Foreland Basin: correlation with Mediterranean and Atlantic Plateboundary events. - Netherl. J. Geosci. - Geol. Mijnbouw 85 (2): $77-129$.

Sittler, C. (1965): Le Palégogène des Fossés Rhénan et Rhodanien. Études sédimentologiques et paléoclimatiques. Mém. Serv. carte géol. d'Alsace et de Lorraine 24: 392 p. 
Spezzaferri, S. (1994): Planktonic foraminiferal biostratigraphy and taxonomy of the Oligocene and lower Miocene in the oceanic record. An overview. - Palaeontographica Italica 81: 1-187.

Spezzaferri, S. \& Coric, S. (2001): Ecology of Karpatian (Early Miocene) foraminifers and calcareous nannoplankton from Laa an der Thaya, Lower Austria: a statistical approach. - Geologica Carpathica 52 (6): 361-374.

Spezzaferri, S. \& Premoli Silva, I. (1991): Oligocene planktonic foraminiferal biostratigraphy and paleoclimatic interpretation from Hole 538A, DSDP Leg 77, Gulf of Mexico. - Palaeogeogr., Palaeoclimatol., Palaeoecol. 83: 217-263.

Spezzaferri, S., Rögl, F., Coric, S. et al. (2004): Paleoenvironmental changes and agglutinated foraminifera across the Karpatian/Badenian (Early/Middle Miocene) boundary in the Styrian Basin (Austria, Central Paratethys). - In: BuBIK, M. \& Kaminski, M.A. (eds.): Proceedings of the Sixth International Workshop on Agglutinated Foraminifera. Grzybowski Found., spec. publ., 423-459.

SPIEgler, D. \& SpezzAfERri, S. (2005): Bolboforma - an overview. - Paläontol. Z. 79 (1): 167-181.

Steininger, F.F., Rögl, F., Carbonnel, G. et al. (1982): Biostratigraphische Gliederung und Korrelation: zentrale und westliche Paratethys, Rhône-Tal und Mediterraner Raum. - In: JunG, P. (ed.): Nouveaux résultats biostratigraphiques dans le Bassin Molassique, depuis le Vorarlberg jusqu'en Haute-Savoie. - Doc. Lab. Géol. Lyon, H.S. 7: 87-91.

Storni, A. (2002): Etude paléontologique et sédimentologique de la carrière d'Altkirch (Alsace, Paléogène) et cartographie des sediments tertiaires et quarternaires de la région de Porrentruy (Jura suisse). - Univ. Fribourg, Diploma thesis, 125 p.

Subbotina, N.N. (1947): Foraminifery datskikh I paleogenovykh otlozhenii severnogo Kavkaza. - In: Mikrofauna neftyanyky mestorozhdenii Kavkaza, Emby I Srednei Azii Trudy, Vsesoyznogo Nauchno-Issledovatel'skogo Geologorazvedochnogo Instituta (VNIGRI) 1:39-160.

Subbotina, N.N. (1953): Iskopaemye foraminifery SSSR (Globogerinidy, Khantkenininidy I Globorotaliidy). - Trudy,
Vsesoyznogo Nauchno-Issledovatel'skogo Geologorazvedochnogo Instituta (VNIGRI) 76: $296 \mathrm{p}$.

Sztrakos, K. \& DU Fornel, E. (2003): Stratigraphie, paléoécologie et foraminifères du Paleogène des Alpes Maritimes et des Alpes de Haute-Provence (Sud-Est de la France). Rév. Micropaléontol. 46 (4): 229-267.

Terquem, M. (1882): Les foraminifères de l'Éocène des environs de Paris. - Mém. Soc. Géol. France 3 (2): 1-193.

Toumarkine, M. \& Bolli, H.M. (1970): Évolution de Globorotalia cerroazuelensis (Cole) dans l'Éocène Moyen et Supérieur de Possagno (Italie). - Rev. Micropaléontol. 13: 131-145.

Toumarkine, M. \& Bolli, H.M. (1975): Foraminiferes planctoniques de l'Éocène moyen et supérieur de la Coupe de Possagno. - Schweiz. Paläontol. Abh. 97: 69-185.

Ujetz, B. (1996): Micropaleontology of Paleogene deep-water sediments, Haute-Savaoie, France. - Publ. Dép. Géol. et Paléontol. Univ. Genève 22: 1-149.

Ujetz, B., Kindler, P. \& Wernli, R. (1994): Oligocene Foraminifera from the Val d'Illiez Formation (Haute-Savoie, France): refined biostratigraphy and paleoecological analysis. - Rév. Micropaléontol. 37 (4): 275-287.

UstASZEWSKI, K. (2004): Reactivation of pre-existing crustal discontinuities: the southern Upper Rhine Graben and the northern Jura Mountains - a natural laboratory. - Univ. Basel, $\mathrm{PhD}$ thesis, $145 \mathrm{p}$.

Vinken, R. (comp.) (1988): The North West European Tertiary Basins. Results of the international geological correlation programme, project no. 124. - Geol. Jahrb. A 100: 1-508.

Walker, G. \& JACOB, E. (1798): In AdAMs, G.: Essays on the Microscope. - F. Kanmacher, (2nd) ed.: 712 p.

Weidmann, M., Homewood, P. \& Fasel, J.-M. (1982): Sur les terrains subalpins et le Wildflysch entre Bulle et Montreux. - Bull. Soc. Vaudoise Sci. Nat. 362 (76): 151-183.

Wenger, W.F. (1987): Die Foraminiferen des Miozäns der bayerischen Molasse und ihre stratigraphische sowie paläogeographische Auswertung. - Zitteliana 16: 173-340.

\section{Appendix: Foraminifera species list}

\begin{tabular}{|c|c|}
\hline $\begin{array}{l}\text { Acarinina bullbrooki (BolLi 1957) } \\
* 1957 \text { Globorotalia bullbrooki - BolLI: 167; pl. 38, fig. 5a-c. }\end{array}$ & Plate 13, fig. $4 a-c$ \\
\hline $\begin{array}{l}\text { Acarinina collactea (FINLAY 1939) } \\
* 1939 \text { Globorotalia collactea - FINLAY: 327; pl. 29, figs. 164, } 165 .\end{array}$ & Plate 13 , fig. $5 \mathrm{a}-\mathrm{c}$ \\
\hline $\begin{array}{l}\text { Acarinina decepta (MARTIN 1943) } \\
* 1943 \text { Globigerina decepta - MARTIN: 114; pl. 7, fig. 2a-c. }\end{array}$ & Plate 13, fig. 6a-c \\
\hline $\begin{array}{l}\text { Acarinina matthewsae (BLow 1979) } \\
\text { * } 1979 \text { Globorotalia (Acarinina) matthewsae - Blow: 935-937; pl. 170, figs. 1-9; pl. 179, figs. } \\
\text { 1, 2; pl. 187, fig. 5; pl. 203, figs. 3, 4; pl. 204, figs. 1-5; pl. 205, figs. 1-6. }\end{array}$ & Plate 13, fig. $7 \mathrm{a}-\mathrm{c}$ \\
\hline $\begin{array}{l}\text { Acarinina medizzai (Toumarkine \& Bolli 1975) } \\
* 1975 \text { Globigerina medizzai - Toumarkine \& Bolli: 77; pl. 5, figs. 8-22; pl. 6, figs. 1-8. }\end{array}$ & Plate 13 , fig. $8 \mathrm{a}-\mathrm{c}$ \\
\hline $\begin{array}{l}\text { Acarinina pentacamerata (SuввотіNA 1947) } \\
* 1947 \text { Globorotalia pentacamerata - SuввотіNA: } 128-129 ; \text { pl. 7, figs. 12-17; pl. 9, figs. } 24-26 .\end{array}$ & Plate 14, fig. 1a-c \\
\hline
\end{tabular}




\begin{tabular}{|c|c|}
\hline $\begin{array}{l}\text { Acarinina primitiva (FINLAY 1947) } \\
* 1947 \text { Globoquadrina primitiva - FINLAY: 291; pl. 8, figs. 129-134. }\end{array}$ & Plate 14, fig. 2a-c \\
\hline $\begin{array}{l}\text { Acarinina pseudotopilensis (SubBоtina 1953) } \\
* 1953 \text { Truncorotaloides pseudotopilensis - SubBotina: 227; pl. 21, figs. 8a-c, 9a-c; pl. 22, } \\
\text { figs. 1a-c, 2a-c, 3a-c. }\end{array}$ & Plate 14, fig. 3a, b \\
\hline $\begin{array}{l}\text { Acarinina rugosoaculeata (SubBotina 1953) } \\
* 1953 \text { Acarinina rugosoaculeata - SUвBOTINA: 235; pl. 25, figs. 4a-c, 5a-c, 6a-c. }\end{array}$ & Plate 14, fig. 4a-c \\
\hline $\begin{array}{l}\text { Almaena osnabrugensis (ROEMER 1838) } \\
\text { * } 1838 \text { Planulina Osnabrugensis v.M. - ROEMER: 390; pl. 3, fig. } 58 .\end{array}$ & Plate 10 , fig. $8 \mathrm{a}, \mathrm{b}$ \\
\hline $\begin{array}{l}\text { Ammobaculites agglutinans (D'ORBIGNY 1846) } \\
{ }^{*} 1846 \text { Spirolina agglutinans - D' OrbignY: 137; pl. 7, figs. 10-12. }\end{array}$ & Plate 1, figs. 13a, b, 14 \\
\hline Ammobaculites? sp. & Plate 1 , fig. $15 a, b$ \\
\hline $\begin{array}{l}\text { Ammodiscus incertus (D'Orbigny 1839) } \\
{ }^{*} 1839 \text { Operculina incerta, D'OrB. - D'ORBIGNY: 49; pl. 6, figs. 16, } 17 .\end{array}$ & Plate 1, fig. 6a, b \\
\hline $\begin{array}{l}\text { Angulogerina cf. angulosa (Williamson 1858) } \\
1998 \text { Angulogerina cf. angulosa (WILliamsON) - Cicha et al.: 80; pl. 54, figs. 3, } 4 .\end{array}$ & Plate 8 , figs. 10a, b, 11a, b \\
\hline $\begin{array}{l}\text { Angulogerina globosa (STOLTZ 1925) } \\
{ }^{*} 1925 \text { Uvigerina tenuistriata D'ORB. var. globosa nov. var. - STOLTZ: 130, fig. } 2 .\end{array}$ & Plate 8 , fig. 12a, b \\
\hline $\begin{array}{l}\text { Angulogerina muralis (TERQUEM 1882) } \\
{ }^{*} 1882 \text { Uvigerina muralis - TERQUEM: 119; pl. 20, figs. 26-29. }\end{array}$ & Plate 8 , fig. 13a, b \\
\hline $\begin{array}{l}\text { Angulogerina oligocaenica (ANDREAE 1894) } \\
* 1894 \text { Uvigerina oligocaenica - ANDREAE: 50; text-fig. } 1 .\end{array}$ & Plate 8, fig. 14a, b \\
\hline $\begin{array}{l}\text { Aubignyna kiliani (ANDREAE 1884) } \\
\text { * } 1884 \text { Pulvinulina Kiliani } \text { n. sp. - ANDREAE: 255; pl. 11, fig. 1a-c. }\end{array}$ & Plate 11, fig. 5a-c \\
\hline $\begin{array}{l}\text { Bathysiphon taurinensis SACCO, } 1893 \\
{ }^{*} 1893 \text { Bathysiphon taurinensis - SACCO: } 168 \text {, fig. } 2 .\end{array}$ & Plate 1, fig. 1a, b \\
\hline $\begin{array}{l}\text { Bigenerina nodosaria acuta KLAEHN, } 1917 \\
\text { * } 1917 \text { Bigenerina nodosaria var. acuta - KLÄHN: 32; pl. 9, figs. 2a-c, } 3 .\end{array}$ & Plate 3, fig. 11a, b \\
\hline $\begin{array}{l}\text { Bolivina beyrichi Reuss, } 1851 \\
* 1851 \text { Bolivina beyrichi }- \text { Reuss: } 83 ; \text { pl. } 6 \text {, fig. } 51 .\end{array}$ & Plate 7, figs. 3a, b, 4a, b \\
\hline $\begin{array}{l}\text { Bolivina crenulata Cushman, } 1936 \\
\text { * } 1936 \text { Bolivina crenulata - Cushman: 50; pl. 7, fig. } 13 .\end{array}$ & Plate 7, figs. 5, 6a, b \\
\hline $\begin{array}{l}\text { Bolivina elongata HantKen, } 1875 \\
* 1875 \text { Bolivina elongata - HANTKEN: 65; pl. 7, fig. } 14 .\end{array}$ & Plate 7, fig. 8a, b \\
\hline $\begin{array}{l}\text { Bolivina melettica ANDREAE, } 1884 \\
{ }^{*} 1884 \text { Bolivina melettica n. sp. - ANDREAE: 165; pl. 11, fig. } 5 .\end{array}$ & Plate 7, fig. 9a, b \\
\hline $\begin{array}{l}\text { Bolivina semistriata nobilis HANTKEN, } 1875 \\
{ }^{*} 1868 \text { Bolivina nobilis - HANTKEN: 56; pl. 15, fig. } 4 .\end{array}$ & Plate 7 , fig. 10a, b \\
\hline $\begin{array}{l}\text { Buccella granulata (LAUTENSCHLAEGER, 1953) } \\
* 1953 \text { Eponides granulatus - LAUTENSCHLÄGER: 119; pl. 17, figs. 5a-c, 6a-c [in MYATLYUK]. }\end{array}$ & Plate 11, fig. 6a-c \\
\hline $\begin{array}{l}\text { Bulimina alsatica Cushman \& Parker, } 1937 \\
\text { * } 1937 \text { Bulimina alsatica - Cushman \& Parker: 39; pl. 4, figs. 6, 7. }\end{array}$ & Plate 7, figs. 14a, b, 15a, b \\
\hline $\begin{array}{l}\text { Bulimina sculptilis Cushman, } 1923 \\
\text { * } 1923 \text { Bulimina sculptilis - Cushman: 23; pl. 3, fig. } 3 .\end{array}$ & Plate 7, figs. 16a, b, 17 \\
\hline $\begin{array}{l}\text { Cancris turgidus Cushman \& Todd, } 1942 \\
* 1942 \text { Cancris turgidus - Cushman \& TodD: 92; pl. 24, fig. 3a-c, 4a-c. }\end{array}$ & Plate 9, fig. 4a-c \\
\hline $\begin{array}{l}\text { Catapsydrax echinatus Bolli, } 1957 \\
* 1957 \text { Catapsydrax echinatus - BolLI: 165; pl. 37, figs. 2a-c, 3a-c, 4, 5a, b. }\end{array}$ & Plate 18, figs. 1a-c, 2a-c \\
\hline $\begin{array}{l}\text { Catapsydrax martini (BLOW \& BANNER 1962) } \\
* 1962 \text { Globigerinita martini martini - BLOW \& BANNER: 110-111; pl. 14, fig. O. }\end{array}$ & Plate 18 , fig. $3 a-c$ \\
\hline
\end{tabular}




\begin{tabular}{|c|c|}
\hline $\begin{array}{l}\text { Catapsydrax unicavus Bolli, LoeBlich \& TAPPAN, } 1957 \\
* 1957 \text { Catapsydrax unicavus - Bolli et al.: 37; pl. 7, fig. } 9 .\end{array}$ & Plate 18 , fig. $4 \mathrm{a}-\mathrm{c}$ \\
\hline $\begin{array}{l}\text { Chiloguembelina cubensis (PALmer 1934) } \\
* 1934 \text { Guembelina cubensis - PALMER: 74, figs. 1-6. }\end{array}$ & Plate 15 , figs. $7 \mathrm{a}, \mathrm{b}, 8$ \\
\hline $\begin{array}{l}\text { Chiloguembelina midwayensis (CUSHMAN 1940) } \\
* 1940 \text { Guembelina midwayensis - CusHMAN: 65; pl. 11, fig. } 15 .\end{array}$ & Plate 15 , fig. 5 \\
\hline $\begin{array}{l}\text { Chiloguembelina wilcoxensis (Cushman \& Ponton 1932) } \\
* 1932 \text { Guembelina wilcoxensis - Cushman \& Ponton: 66; pl. 8, figs. 16, 17a, b. }\end{array}$ & Plate 15 , fig. 6a, b \\
\hline $\begin{array}{l}\text { Cibicides amphisyliensis (ANDREAE 1884) } \\
* 1884 \text { Truncatulina amphysiliensis - ANDREAE: 255; pl. 10, fig. 30a-c. }\end{array}$ & Plate 10, fig. 2a, b \\
\hline $\begin{array}{l}\text { Cibicidoides lucidus (REuss 1866) } \\
* 1866 \text { Truncatulina lucida - REuss: 160; pl.4, fig. 15a-c. }\end{array}$ & Plate 9, fig. 9a-c \\
\hline $\begin{array}{l}\text { Cibicidoides oligocenicus (SAmoYlova 1946) } \\
* 1946 \text { Cibicides dutemplei var. oligocenica - SAMoYlova: 96, figs. 34-36. }\end{array}$ & Plate 9 , fig. $10 a-c$ \\
\hline $\begin{array}{l}\text { Cibicidoides roemeri (REuss 1856) } \\
* 1856 \text { Rotalia roemeri - REuss: } 240 \text {; pl. 4, fig. 52a-c. }\end{array}$ & Plate 9, fig. 11a-c \\
\hline $\begin{array}{l}\text { Cibicidoides? weinkauffi (REUss 1863) } \\
* 1863 \text { Rosalina weinkauff - REUss: 68; pl. 8, fig. 97a-c, }\end{array}$ & Plate 10 , fig. $1 \mathrm{a}-\mathrm{c}$ \\
\hline Colomia sp. & Plate 8 , fig. $15 \mathrm{a}, \mathrm{b}$ \\
\hline $\begin{array}{l}\text { Contusotruncana fornicata (PLUMMER 1931) } \\
* 1931 \text { Globotruncana fornicata - PLUMMER: 130; pl. 13, figs. 4-6. }\end{array}$ & Plate 13 , fig. $1 \mathrm{a}-\mathrm{c}$ \\
\hline $\begin{array}{l}\text { Cycloforina gracilis (KARRER 1867) } \\
* 1867 \text { Quinqueloculina gracilis - KARRER: 361; pl. 3, fig. 2a-c. }\end{array}$ & Plate 4, fig. $4 a-c$ \\
\hline $\begin{array}{l}\text { Cycloforina hauerina D' ORBIGNY, } 1846 \\
{ }^{*} 1846 \text { Quinqueloculina hauerina - D'ORBIGNY: 286; pl. 13, figs. 15-16. }\end{array}$ & Plate 4, fig. 5a-c \\
\hline $\begin{array}{l}\text { Cycloforina ludwigi (Reuss 1866) } \\
* 1866 \text { Quinqueloculina ludwigi-Reuss: 126; pl. 1, fig. } 12 .\end{array}$ & Plate 4, fig. 6a, b \\
\hline $\begin{array}{l}\text { Dentoglobigerina cf. galavisi (BERMÚDEZ 1961) } \\
1987 \text { Dentoglobigerina cf. D. galavisi (BERMÚDEZ) - REISER: 110-111; pl. 16, figs. 1-2, } 5 \text {. }\end{array}$ & Plate 18 , fig. $7 \mathrm{a}-\mathrm{c}$ \\
\hline Discorbinoides sp. & Plate 9, fig. 7a-c \\
\hline $\begin{array}{l}\text { Eggerella? irregularis (HANTKEN 1875) } \\
* 1875 \text { Gaudryina irregularis - HANTKEN: 12; pl. 1, fig. } 7 .\end{array}$ & Plate 3, fig. 3a, b \\
\hline $\begin{array}{l}\text { Elphidiella minuta (REUss 1865) } \\
* 1865 \text { Polystomella minuta - REUss: 44; pl.4, fig. } 6 .\end{array}$ & Plate 11 , fig. 10a, b \\
\hline $\begin{array}{l}\text { Favulina hexagona (Williamson 1848) } \\
* 1848 \text { Entosolenia squamosa (MonTAGU) var. } \gamma \text {, hexagona - Williamson: 20; pl. 2, fig. } 23 .\end{array}$ & Plate 6, fig. 15a, b \\
\hline $\begin{array}{l}\text { Fissurina orbignyana orbignyana (SEGUENZA 1862) } \\
* 1862 \text { Fissurina (Fissurine) orbignyana - SEGUENZA: 66; pl. 2, figs. 25, } 26 .\end{array}$ & Plate 6, fig. 16a, b \\
\hline $\begin{array}{l}\text { Fissurina orbignyana striata FRIESE, } 1951 \\
* 1951 \text { Lagena orbignyana (SEGUENZA) subsp. striata - FRIESE: 27; pl. 11, fig. } 35 .\end{array}$ & Plate 7 , fig. 1a, b \\
\hline $\begin{array}{l}\text { Flintina cf. variolaria CUvillier \& SzaKall, } 1949 \\
* 1949 \text { Flintina variolaria - CUvillier \& SzAKALl: 44; pl. 18, fig. } 22 .\end{array}$ & Plate 4, fig. 10a, b \\
\hline $\begin{array}{l}\text { Frondicularia cf. oblonga RoEmer, } 1838 \\
* 1838 \text { Frondicularia oblonga - ROEMER: 382; pl. 3, figs. 4a, b, 6a-c. }\end{array}$ & Plate 5, fig. 12 \\
\hline $\begin{array}{l}\text { Gaudryinopsis austriacus RöGL, } 1998 \\
\text { * } 1998 \text { Gaudryinopsis austriacus RöGL nov. spec. - CicHA et al.: 69-71, figs. 50, 51; pl. 7, figs. } \\
6-8 .\end{array}$ & Plate 3, fig. 2a, b \\
\hline Glabratella? sp. & Plate 9, fig. $8 \mathrm{a}-\mathrm{c}$ \\
\hline $\begin{array}{l}\text { Globigerina ciperoensis BOLLI, } 1954 \\
* 1954 \text { Globigerina ciperoensis - BOLLI: 1; pl. 2, figs. 2-5. }\end{array}$ & Plate 16 , fig. $1 \mathrm{a}-\mathrm{c}$ \\
\hline
\end{tabular}


Globigerina praebulloides BLOw, 1959

* 1959 Globigerina praebulloides - BLow: 180; pl. 8, fig. 47a-c; pl. 9, fig. 48.

"Globigerina" venezuelana HedBERG, 1937

* 1937 Globigerina venezuelana - HEDBERG: 681; pl. 92, fig. 7a, b.

Globigerinatheka micra (SHuTsKAYA 1958)

* 1958 Globigerinoides subconglobatus SHUTSKaya var. micra - SHUTSKaya: 87; pl. 1, figs. 1-3.

Globigerinatheka semiinvoluta (KEIJZER 1945)

* 1945 Globigerinoides semiinvolutus - KeIJZER: 206; pl. 4, fig. 58a-e.

Globigerinella obesa (BoLli 1957)

* 1957 Globorotalia obesa-BoLli: 119; pl. 29, fig. 2a-c.

Globocassidulina subglobosa (BRADY 1881)

* 1881 Cassidulina subglobosa-BRADY: 60.

Globorotaloides cf. carcoselleensis ToumARKINE \& BOLLI, 1975

* 1975 Globorotaloides carcoselleensis - TOUMARKINE \& BOLLI: 81; pl. 5, figs. 23-28.

Globorotaloides variabilis BOLLI, 1957

* 1957 Globorotaloides variabilis - Bolli 117, pl. 27, figs. 15a, b, 16a, b, 17a, b, 18a, b, 19a-c,

$20 \mathrm{a}-\mathrm{c}$.

Globotruncana arca? (CUshman 1926)

* 1926 Pulvinulina arca - Cushman: 23; pl. 3, fig. 1a-c.

Globotruncana linneiana (D'ORBIGNY 1839)

* 1839 Rosalina linneiana-D'OrbignY: 101; pl. 15, figs. 10-12.

Globotruncanella? sp.

Globulina gibba D'ORBIGNY, 1846

* 1846 Globulina gibba-D' ORBIGNY: 227; pl. 13, figs. 13, 14.

Guembelitria sp.

Guttulina communis D'ORBIGNY, 1826

* 1826 Polymorphina (GutTuline) communis - D'ORbigny: 266, pl. 12, figs. 1-4.

Gyroidina brockerti REISER, 1987

* 1987 Gyroidina brockerti n. sp. - REISER: 102; pl. 12, figs. 14, 15; pl. 13, fig. 1.

Gyroidinoides girardanus (REuss 1851)

* 1851 Rotalina girardana-Reuss: 73; pl. 5, fig. 34a-c.

Gyroidinoides mamillatus (ANDREAE 1884)

* 1884 Rotalia girardana Rss var. mamillata n. v. - ANDREAE: 142; pl. 9, fig. 4.

Hansenisca soldanii (D'ORBIGNY 1826)

* 1846 Rotalina Soldanii D'OrbignY - D'OrbignY: 155; pl. 8, figs. 10-12.

Heterohelix globulosa (EHRENBERG 1840)

* 1840 Textularia globulosa - Ehrenberg: 135; pl. 4, figs. $2 \beta, 4 \beta, 5 \beta, 7 \beta, 8 \beta$; [vol. 1838].

Heterohelix striata (EHRENBERG 1840)

* 1840 Textularia striata - Ehrenberg: 135; pl. 4, fig. $1 \alpha-\alpha^{\prime}, 2 \alpha, 3 \alpha, 9 \alpha$; [vol. 1838].

Heterolepa dutemplei (D'ORBIGNY 1846)

* 1846 Rotalina dutemplei-D'Orbigny: 157, 158; pl. 8, fig. 19-21.

Hyalinonetrion gracillimum (SEGUENZA 1862)

* 1862 Amphora Gracillima - SEguenza: 51; pl. 1, fig. 37.

Hyperammina sp.

Karreriella chilostoma (REUss 1852)

* 1852 Textularia chilostoma - Reuss: 18, figs. a, b.

Karreriella siphonella (REUss 1851)

* 1851 Gaudryina siphonella - REuss: 78; pl. 5, figs. 40-42.

Karreriella siphonella exilis HAGN, 1952

* 1952 Karreriella siphonella (REuss) var. exilis - HAGN: 139; pl. 1, fig. 7; pl. 2, fig. 9.

Plate 16, fig. 2a-c, 3a, b

Plate 16, fig. $4 a-c$

Plate 15, fig. 3a-c

Plate 15, fig. 4a-c

Plate 17, fig. 4a-c

Plate 7, fig. 11a, b

Plate 18, fig. 5a-c

Plate 18, fig. 6a-c

Plate 12, fig. 6a-c

Plate 12, fig. $5 \mathrm{a}-\mathrm{c}$

Plate 12 , fig. $7 \mathrm{a}-\mathrm{c}$

Plate 6, fig. 13a, b

Plate 12, fig. 3

Plate 6, fig. 14a, b

Plate 11, fig. 1a-c

Plate 11, fig. 2a-c

Plate 11, fig. 3a-c

Plate 11, fig. 4a-c

Plate 12, fig. 1a, b

Plate 12, fig. 2a, b

Plate 10, fig. 10a-c

Plate 6, fig. 12

Plate 1, fig. 2a, b

Plate 3, figs. $4 a-c, 5 a-c$

Plate 3, figs. 6a, b, 7

Plate 3, figs. 8-10 


\begin{tabular}{|c|c|}
\hline $\begin{array}{l}\text { Laevidentalina communis (D'ORBIGNY 1846) } \\
* 1846 \text { Dentalina communis - D'ORBIGNY: 45, pl. 1, figs. 52-56. }\end{array}$ & Plate 5 , fig. $3 a-c$ \\
\hline $\begin{array}{l}\text { Laevidentalina elegans (D'ORBIGNY 1846) } \\
* 1846 \text { Dentalina elegans - D'ORBIGNY: 45, pl. 1, figs. 52-56. }\end{array}$ & Plate 5, fig. 4 \\
\hline $\begin{array}{l}\text { Lagena amphora REUSS, } 1863 \\
* 1863 \text { Lagena amphora - REUSs: 330; pl. 4, fig. } 57 .\end{array}$ & Plate 6, fig. 7a, b \\
\hline $\begin{array}{l}\text { Lagena gracilicosta REUSs, } 1863 \\
* 1863 \text { Lagena gracilicosta - REUss: 327; pl. 3, figs. 42, } 43 .\end{array}$ & Plate 6, fig. 8a, b \\
\hline $\begin{array}{l}\text { Lagena isabella isabella (D'ORBIGNy 1838) } \\
* 1838 \text { Oolina isabella-D'ORBIGNy: 20; pl. 5, figs. 7, } 8 .\end{array}$ & Plate 6, fig. 9a, b \\
\hline $\begin{array}{l}\text { Lagena isabella conscripta CUSHMAN \& BARKSDALE, } 1930 \\
* 1930 \text { Lagena isabella conscripta - CUSHMAN \& BARKSDALE: 66; pl. 12, fig. } 4 .\end{array}$ & Plate 6, fig. 10a, b \\
\hline $\begin{array}{l}\text { Lagena sulcata (WALter \& JAсов 1798) } \\
\text { * } 1798 \text { Serpula (Lagena) sulcata W. \& J. - WALter \& JACOB: 634; pl. 14, fig. } 5 .\end{array}$ & Plate 6, fig. 11a, b \\
\hline Lagenammina sp. & Plate 1, fig. 4a, b \\
\hline $\begin{array}{l}\text { Lenticulina insignis (Reuss 1865) } \\
* 1865 \text { Cristellaria (Robulina) insignis - Reuss: 466; pl. 5, fig. } 4 .\end{array}$ & Plate 5 , fig. $13 a-c$ \\
\hline $\begin{array}{l}\text { Lenticulina reniformis (D'ORBIGNY 1846) } \\
* 1846 \text { Cristellaria reniformis - D'ORBIGNY: 88; pl.3, figs. 39, } 40 .\end{array}$ & Plate 5, fig. 14a-d \\
\hline Lenticulina sp. juv. & Plate 5, fig. $15 a-c$ \\
\hline $\begin{array}{l}\text { Macroglobigerinelloides ultramicrus (SuввотілA 1949) } \\
\text { * } 1949 \text { Globigerinella ultramicra - SuввотілA: 33; pl. 2, figs. 17, } 18 .\end{array}$ & Plate 13 , fig. $3 a-c$ \\
\hline $\begin{array}{l}\text { Marginotruncana pseudolinneiana PESSAGNO, } 1967 \\
\text { * } 1967 \text { Marginotruncana pseudolinneiana - PESSAGNO: 310; pl. 65, figs. 24-27, pl. 76, figs. 1-3. }\end{array}$ & Plate 12 , figs. $8 \mathrm{a}-\mathrm{c}, 9 \mathrm{a}, \mathrm{b}$ \\
\hline $\begin{array}{l}\text { Marginulina hirsuta D'ORBIGNY, } 1826 \\
\text { * } 1826 \text { Marginulina hirsuta-D'ORBIGNY: 259, no } 9 .\end{array}$ & Plate 5, fig. 16a, b \\
\hline $\begin{array}{l}\text { Marginulinopsis cf. jugleri (REuss 1851) } \\
* 1851 \text { Cristellaria jugleri - REuss: } 89 \text {, pl. 4, fig. 19a, b. }\end{array}$ & Plate 5 , fig. $17 \mathrm{a}-\mathrm{c}$ \\
\hline $\begin{array}{l}\text { Melonis affinis (REuss 1851) } \\
* 1851 \text { Nonionina affinis - ReUss: } 72 \text {; pl. 5, fig. } 32 .\end{array}$ & Plate 10, fig. $5 a-c$ \\
\hline $\begin{array}{l}\text { Morozovella lehneri (CUSHMAN \& JARVIS 1929) } \\
\text { * } 1929 \text { Globorotalia lehneri-CUSHMAN \& JARVIS: 17; pl. 3, fig. 16a-c. }\end{array}$ & Plate 14 , fig. $8 \mathrm{a}-\mathrm{c}$ \\
\hline $\begin{array}{l}\text { Morozovella subbotinae (Morozova 1939) } \\
* 1939 \text { Globorotalia subbotinae - Morozova: } 80 \text { [Russian]; pl. 2, figs. 16, } 17 .\end{array}$ & Plate 15 , fig. $1 \mathrm{a}-\mathrm{c}, 2 \mathrm{a}-\mathrm{c}$ \\
\hline $\begin{array}{l}\text { Muricohedbergella delrioensis (CARSEY 1926) } \\
\text { * } 1926 \text { Globigerina cretacea D'ORBIGNY var. delrioensis - CARSEY: } 43 .\end{array}$ & Plate 12 , fig. $4 a-c$ \\
\hline Nodosaria sp. & Plate 5, fig. 6a, b \\
\hline $\begin{array}{l}\text { Nodosaria capitata striatissima ANDREAE, } 1884 \\
* 1884 \text { Nodosaria capitata BOLL. var. striatissima n. v. - ANDREAE: 112; pl. 10, figs. 4, } 5 \text {. }\end{array}$ & Plate 5 , fig. 5 \\
\hline $\begin{array}{l}\text { Nodosaria soluta REUSs, } 1855 \\
* 1851 \text { Nodosaria soluta - REUss: 322; pl. 12, fig. } 12 .\end{array}$ & Plate 5, figs. 7,8 \\
\hline $\begin{array}{l}\text { Paragloborotalia nana (Bolli 1957) } \\
* 1957 \text { Globorotalia opima nana - BolLI: 118; pl. 28, fig. } 3 .\end{array}$ & Plate 17 , fig. $7 a-c$ \\
\hline $\begin{array}{l}\text { Pararotalia canui (Cushman 1928) } \\
\text { * } 1856 \text { Rotalia stellata - REuss: 242; pl. 5, fig. } 54 . \\
1928 \text { Rotalia canui nom. nov. - Cushman: 55; pl. 3, fig. } 2 .\end{array}$ & Plate 11, fig. $9 \mathrm{a}-\mathrm{c}$ \\
\hline Peneroplis? sp. & Plate 5, fig. 2 \\
\hline $\begin{array}{l}\text { Planorbulina difformis RoEmer, } 1838 \\
\text { * } 1838 \text { Planorbulina difformis - ROEMER: 390; pl. 3, fig. 59a-c. }\end{array}$ & Plate 10, fig. 3a, b \\
\hline $\begin{array}{l}\text { Planularia costata (REUss 1866) } \\
\text { * } 1866 \text { Cristellaria (Robulina) depauperata Reuss var. costata - REUss: 147; pl. 3, fig. 19a, b; } \\
\text { pl. 4, fig. 5a, b, } 6 \text {. }\end{array}$ & Plate 6, figs. 1a-c, $2 a-c$ \\
\hline
\end{tabular}




\begin{tabular}{|c|c|}
\hline $\begin{array}{l}\text { Pleurostomella alternans SCHWAGER, } 1866 \\
\text { * } 1866 \text { Pleurostomella alternans - SCHWAGER: 238; pl. 6, figs. 79, } 80 .\end{array}$ & Plate 8 , fig. 16a, b \\
\hline Porosononion sp. & Plate 10, fig. $4 a-c$ \\
\hline $\begin{array}{l}\text { Praeglobobulimina coprolithoides (ANDREAE 1884) } \\
\text { * } 1884 \text { Bulimina coprolithoides - ANDREAE: 213; pl. 6, fig. 4a-d. }\end{array}$ & Plate 7 , fig. 13a, b \\
\hline $\begin{array}{l}\text { Praeglobotruncana delrioensis (PlUMmeR 1931) } \\
* 1931 \text { Globorotalia delrioensis - PlumMER: 199, 200; pl. 13, fig. 2a-c. }\end{array}$ & Plate 12 , fig. $10 \mathrm{a}-\mathrm{c}$ \\
\hline $\begin{array}{l}\text { Pseudohastigerina barbadoensis BLOw, } 1969 \\
* 1969 \text { Pseudohastigerina barbadoensis - BLow: 409, 410; pl. 53, figs. 7-9; pl. 54, figs. 1-3, } 7 .\end{array}$ & Plate 17, fig. 5a, b \\
\hline $\begin{array}{l}\text { Pseudohastigerina micra (COLE 1927) } \\
* 1927 \text { Nonion micrus - Cole: 22, pl. 5, fig. } 12 .\end{array}$ & Plate 17, fig. 6a, b \\
\hline $\begin{array}{l}\text { Pullenia bulloides (D'Orbigny 1846) } \\
* 1846 \text { Nonionina bulloides D'ORBIGNY - D'ORBIGNy: 107; pl. 5, figs. 9, } 10 .\end{array}$ & Plate 10, fig. 6a, b \\
\hline $\begin{array}{l}\text { Pullenia quinqueloba (REUss 1851) } \\
\text { * } 1851 \text { Nonionides quinqueloba - REUss: 71; pl. 5, fig. } 31 .\end{array}$ & Plate 10, fig. 7a, b \\
\hline $\begin{array}{l}\text { Pygmaeoseistron globosum (Montagu 1803) } \\
\text { * } 1803 \text { Vermiculum globosum - Montagu: 523; [pl. 1, fig. 8, from Walker \& Boys 1784]. }\end{array}$ & Plate 6, fig. 3a, b \\
\hline $\begin{array}{l}\text { Pygmaeoseistron hispidum (REuss 1863) } \\
\text { * } 1862 \text { Lagena hispida - REuss: 335; pl. 6, fig. } 77 .\end{array}$ & Plate 6, fig. 4a, b \\
\hline $\begin{array}{l}\text { Pygmaeoseistron rudis (REUss 1863) } \\
\text { * } 1863 \text { Lagena rudis - REUss: 336; pl. 6, fig. } 82 .\end{array}$ & Plate 6, fig. 5a, b \\
\hline $\begin{array}{l}\text { Pygmaeoseistron vulgaris apiculatum (REUSs 1870) } \\
\text { * } 1870 \text { Lagena vulgaris WILLIAMSON var. apiculata - REUSS: 466; [pl. 2, figs. 4, 5, } \\
\text { from vON SCHLICHT 1870]. }\end{array}$ & Plate 6, fig. 6a, b \\
\hline $\begin{array}{l}\text { Pyramidulina bactridium (Reuss 1866) } \\
\text { * } 1866 \text { Nodosaria (Nodosaria) bactridium - Reuss: 130; pl. 1, figs. 24, } 25 .\end{array}$ & Plate 5, fig. 9 \\
\hline $\begin{array}{l}\text { Pyramidulina herrmanni (ANDREAE 1884) } \\
\text { * } 1884 \text { Nodosaria Herrmanni n. sp. - ANDREAE: ?; pl. 10, fig. } 2 .\end{array}$ & Plate 5, fig. 10a, b \\
\hline $\begin{array}{l}\text { Pyramidulina ludwigi (Reuss 1866) } \\
\text { * } 1866 \text { Nodosaria (Dentalina) ludwigi-Reuss: 135; pl. 2, fig. } 23 .\end{array}$ & Plate 5, fig. 11a, b \\
\hline $\begin{array}{l}\text { Pyrgoella globiformis (KARRER 1867) } \\
* 1867 \text { Biloculina globiformis - KARRER: 357; pl. 2, fig. 1a-c. }\end{array}$ & Plate 4, fig. 11a, b \\
\hline $\begin{array}{l}\text { Quinqueloculina buchiana D'ORBIGNY, } 1846 \\
{ }^{*} 1846 \text { Quinqueloculina buchiana - D'ORBIGNY: 289; pl. 18, figs. 13-15. }\end{array}$ & Plate 4, fig. $7 a-c$ \\
\hline $\begin{array}{l}\text { Quinqueloculina gregaria ANDREAE, } 1884 \\
* 1884 \text { Quinqueloculina gregaria - ANDREAE: 278; pl. 12, fig. 10a-c, 11, } 12 .\end{array}$ & Plate 4, fig. 8a, b \\
\hline Quinqueloculina sp. & Plate 4, fig. 9a-c \\
\hline $\begin{array}{l}\text { Reophax scorpiurus DenYs DE MONTFORT, } 1808 \\
* 1808 \text { Reophax scorpiurus - DENYS DE MONTFORT: } 331 \text {; text-fig. p. } 330 .\end{array}$ & Plate 1 , fig. 9 \\
\hline $\begin{array}{l}\text { Reophax subfusiformis EARLAND, } 1933 \\
* 1933 \text { Reophax subfusiformis - EARLAND: 74; pl. 2, figs. 16-19. }\end{array}$ & Plate 1 , fig. 10a, b \\
\hline $\begin{array}{l}\text { Repmanina charoides (Jones \& PARKeR 1860) } \\
\text { * } 1860 \text { Trochammina squamata var. charoides - JONES \& PARKER: } 304 .\end{array}$ & Plate 1 , figs. $7 \mathrm{a}, \mathrm{b}, 8 \mathrm{a}, \mathrm{b}$ \\
\hline $\begin{array}{l}\text { Reticulophragmium acutidorsatum (HANTKEN 1868) } \\
\text { * } 1868 \text { Haplophragmium acutidorsatum - HANTKEN: 82; pl. 1, fig. } 1 .\end{array}$ & Plate 2, figs. 4a, b, 5 \\
\hline $\begin{array}{l}\text { Reticulophragmium? acutidorsatum exigua (SCHRODT 1893) } \\
\text { * } 1893 \text { Cyclammina acutidorsata (HANTKEN) var. exigua - SCHRODT: } 735 \text {, text-fig. }\end{array}$ & Plate 2, fig. 6a, b \\
\hline $\begin{array}{l}\text { Reticulophragmium rotundidorsatum (HANTKEN 1875) } \\
\text { * } 1875 \text { Haplophragmium rotundidorsatum - HANTKEN: 10; pl. 1, fig. } 2 .\end{array}$ & Plate 2, figs. 7a, b, 8 \\
\hline Rhizammina? sp. & Plate 1, fig. 3 \\
\hline $\begin{array}{l}\text { Rotalipora brotzeni (SIGAL 1948) } \\
* 1948 \text { Thalmaniella brotzeni-SIgAL: 102; pl. 1, fig. 5a-c; pl. 2, figs. 6a, b, } 7 .\end{array}$ & Plate 13, fig. 2a-c \\
\hline
\end{tabular}




\begin{tabular}{|c|c|}
\hline $\begin{array}{l}\text { Sabellovoluta humboldti (REuss 1851) } \\
\text { * } 1851 \text { Spirolina Humboldti-REUsS: 65; pl. 3, fig. 17, } 18 .\end{array}$ & Plate 2, figs. 1a, b, 2a-c, 3 \\
\hline $\begin{array}{l}\text { Saccammina sphaerica SARS, } 1872 \\
* 1872 \text { Saccammina sphaerica - SARS: 250; figure in CARPENTER (1875), p. 532, fig. 272a-c. }\end{array}$ & Plate 1, fig. 5a, b \\
\hline $\begin{array}{l}\text { Sigmoilinita tenuis (CzJZEK 1848) } \\
* 1848 \text { Quinqueloculina tenuis - CzJzEK: 149; pl. 13, fig. 31-34. }\end{array}$ & Plate 5, fig. 1a-c \\
\hline $\begin{array}{l}\text { Siphonodosaria adolphina (D'ORBIGNy 1846) } \\
\text { * } 1846 \text { Dentalina adolphina-D'ORBIGNY: 50; pl. 2, fig. 18-20. }\end{array}$ & Plate 9, fig. 3 \\
\hline $\begin{array}{l}\text { Siphonodosaria emaciata (REUSS 1851) } \\
\text { * } 1851 \text { Dentalina emaciata - REUSS: 63; pl. 3, fig. } 9 .\end{array}$ & Plate 9, fig. 1 \\
\hline $\begin{array}{l}\text { Siphonodosaria ewaldi (REUSs 1851) } \\
\text { * } 1851 \text { Nodosaria ewaldi-ReUss: 58; pl.3, fig. 2a, b. }\end{array}$ & Plate 9, fig. 2 \\
\hline $\begin{array}{l}\text { "Siphopyrulina" fusiformis (RoEmer 1838) } \\
\text { * } 1838 \text { Polymorphina (Globulinen) fusiformis - RoEmer: 386; pl. 3, fig. 37a, b. }\end{array}$ & Plate 7, fig. 2 \\
\hline $\begin{array}{l}\text { Sphaeroidina variabilis REUss, } 1851 \\
{ }_{*}^{*} 1851 \text { Sphaeroidina variabilis - REUss: } 88 \text {; pl. 7, figs. 61a-c, 62, 63a, b, 64a, b. }\end{array}$ & Plate 9, figs. 5a; b, 6a; b \\
\hline $\begin{array}{l}\text { Spiroloculina canaliculata D'ORBIGNY, } 1846 \\
\text { * } 1846 \text { Spiroloculina canaliculata - D' ORBIGNY: 269; pl. 16, figs. 10-12. }\end{array}$ & Plate 4, fig. 2a-c \\
\hline $\begin{array}{l}\text { Spiroloculina cf. excavata D'ORBIGNY, } 1846 \\
{ }_{*}^{*} 1846 \text { Spiroloculina excavata - D' ORBIGNY: 271; pl. 16, figs. 19-21. }\end{array}$ & Plate 4, fig. 3 \\
\hline $\begin{array}{l}\text { Spiroplectammina aff. laevis cretosa CUSHMAN, } 1932 \\
\text { * } 1932 \text { Spiroplectammina laevis (RoEMER) var. cretosa - CusHmAn: 87; pl. 11, fig. 3a, b. }\end{array}$ & Plate 4, fig. 1a-c \\
\hline $\begin{array}{l}\text { Spiroplectinella carinata (D'ORBIGNY,1846) } \\
* 1846 \text { Textularia carinata - D' ORBIGNY: 247; pl. 14, figs. 32-34. }\end{array}$ & $\begin{array}{l}\text { Plate 2, figs. 9a-c, 10a; b, } \\
11\end{array}$ \\
\hline $\begin{array}{l}\text { Spiroplectinella deperdita (D'ORBIGNy 1846) } \\
\text { * } 1846 \text { Textularia deperdita - D' ORBIGNY: 244; pl. 14, figS. 23-25. }\end{array}$ & Plate 2, fig. 12a; b \\
\hline $\begin{array}{l}\text { Subbotina angiporoides (HorNiBROOK 1965) } \\
* 1965 \text { Globigerina angiporoides - HoRNIBROOK: 835-838, figS. 1a-i, } 2 .\end{array}$ & Plate 16 , fig. $7 \mathrm{a}-\mathrm{c}$ \\
\hline $\begin{array}{l}\text { Subbotina eocaena (GUEMBEL 1868) } \\
\text { * } 1868 \text { Globigerina eocaena - GUEMBEL: 662; pl. 2, fig. 109a; b. }\end{array}$ & Plate 16 , fig. $8 \mathrm{a}-\mathrm{c}$ \\
\hline $\begin{array}{l}\text { Subbotina gortanii (BoRSETTI 1959) } \\
* 1959 \text { Catapsydrax gortanii - BORSETTI: 205-207; pl. 1, fig. 1a-d. }\end{array}$ & Plate 17 , fig. $1 \mathrm{a}-\mathrm{c}$ \\
\hline $\begin{array}{l}\text { Subbotina utilisindex (JENKINS \& ORR 1972) } \\
\text { * } 1972 \text { Globigerina utilisindex - JENKINS \& ORR: 133-135; pl. 1, figS. 1-6, pl. 2, figs. 1-9; pl. 3, } \\
\text { figs. 1-3. }\end{array}$ & Plate 17 , figs. $2 a-c, 3 a-c$ \\
\hline $\begin{array}{l}\text { Subreophax elongatus (GRZYBOWSKI 1898) } \\
\text { * } 1898 \text { Reophax elongata-GRZYBOwsKI: 279; pl. 10, figs. 19, } 20 .\end{array}$ & Plate 1, figs. 11a, b, 12 \\
\hline $\begin{array}{l}\text { Svratkina perlata (ANDREAE 1884) } \\
* 1884 \text { Pulvinulina perlata - ANDREAE: 124; pl. 8, fig. 12a-c. }\end{array}$ & Plate 10, fig. $9 \mathrm{a}-\mathrm{c}$ \\
\hline $\begin{array}{l}\text { Tenuitella munda (JENkINs 1966) } \\
\text { * } 1966 \text { Globorotalia munda - JENKINs: 1121, 1122, fig. } 14 \text { [no. 126-133], fig. } 15 \text { [no. 152-166]. }\end{array}$ & Plate 15 , fig. $9 \mathrm{a}-\mathrm{c}$ \\
\hline $\begin{array}{l}\text { Tenuitella gemma (JENKINs 1966) } \\
\text { * } 1966 \text { Tenuitella gemma - JENKINs: 1115, 1116, 1118; fig. 11.97-103. }\end{array}$ & Plate 15, fig. 10a-c \\
\hline $\begin{array}{l}\text { Siphotextularia labiata (REuss 1861) } \\
\text { * } 1861 \text { Textilaria labiata - ReUSs: 362; pl. 2, fig. 17a-c (fide ELLIS \& MESsinA online). }\end{array}$ & Plate 3 , figs. $12 \mathrm{a}-\mathrm{c}, 13,14$ \\
\hline $\begin{array}{l}\text { Triloculina gibba D'ORBIGNY, } 1846 \\
\text { * } 1846 \text { Triloculina gibba - D'ORBIGNy: 274; pl. 16, figs. 22-24. }\end{array}$ & Plate 4, fig. 12a-c \\
\hline Trochammina sp. & Plate 2, fig. 13a-c \\
\hline $\begin{array}{l}\text { Trochammina cf. quadriloba (GRZYBOwsKi 1896) } \\
\text { * } 1896 \text { Haplophragmium (Reussina) quadrilobum - GRZYBowsKI: 278; pl. 8, fig. } 31 .\end{array}$ & Plate 3, fig. 1a, b \\
\hline
\end{tabular}




\begin{tabular}{|c|c|}
\hline $\begin{array}{l}\text { Turborotalia cocoaensis (CUSHMAN 1928) } \\
* 1928 \text { Globorotalia cocoaensis - CUSHMAN: 75; pl. 10, fig. 3a-c. }\end{array}$ & Plate 14, fig. 5a-c \\
\hline $\begin{array}{l}\text { Turborotalia frontosa (SuBвotina 1953) } \\
\text { * } 1953 \text { Globorotalia frontosa - SubBOTINA: 84; pl. 12, figs. 3a-c, 4a-c, 5a-c, 6a-c, 7a-c. }\end{array}$ & Plate 14, fig. 6a-c \\
\hline $\begin{array}{l}\text { Turborotalia possagnoensis (ToumaRKINE \& BOLli 1970) } \\
\text { * } 1970 \text { Globorotalia cerroazulensis (COLE) subsp. possagnoensis - Toumarkine \& Bolli: 139, } \\
\text { text-fig. 2a-c; pl. 1, figs. 4-9. }\end{array}$ & Plate 14 , fig. $7 \mathrm{a}-\mathrm{c}$ \\
\hline $\begin{array}{l}\text { Turrilina alsatica ANDREAE, } 1884 \\
* 1884 \text { Turrilina alsatica n. sp. typ. - ANDREAE: pl. 8, figs. 18a-c, } 19 .\end{array}$ & Plate 7 , fig. 12a; b \\
\hline $\begin{array}{l}\text { Uvigerina gracilis germanica CUSHMAN \& EDWARDS, } 1938 \\
\text { * } 1938 \text { Angulogerina germanica - CUSHMAN \& EDWARDs: 85; pl. 15, figs. 14-16. }\end{array}$ & $\begin{array}{l}\text { Plate } 8 \text {, figs. 1a; b, 2a; } b \text {, } \\
3 \mathrm{a} ; \mathrm{b}\end{array}$ \\
\hline $\begin{array}{l}\text { Uvigerina cf. multistriata HANT KEN, } 1871 \\
* 1871 \text { Uvigerina multistriata - HANTKEN: 129; pl. 2, fig. } 14 .\end{array}$ & Plate 8 , fig. 4a; b \\
\hline $\begin{array}{l}\text { Uvigerina rudlingensis PAPP, } 1975 \\
* 1975 \text { Uvigerina rudlingensis - PAPP: 238; pl. 1, figs. 1-4. }\end{array}$ & Plate 8, fig. 6a; b \\
\hline $\begin{array}{l}\text { Uvigerina rugosa D'ORBIGNY, } 1852 \\
* 1852 \text { Uvigerina rugosa-D'ORBIGNY: } 194 .\end{array}$ & Plate 8 , fig. $7 \mathrm{a} ; \mathrm{b}$ \\
\hline $\begin{array}{l}\text { Uvigerina tenuistriata Reuss, } 1870 \\
* 1870 \text { Uvigerina tenuistriata - REUss: 485; [figs. 34-37, pl. 22, vON SCHLICHT (1870)]. }\end{array}$ & Plate 8, fig. 8a; b \\
\hline $\begin{array}{l}\text { Uvigerina vicksburgensis CuSHMAN \& ELLISOR, } 1931 \\
* 1931 \text { Uvigerina vicksburgensis - CUSHMAN \& ElLISOR: 54; pl. 7, fig. 7a, b. }\end{array}$ & Plate 8, fig. 9a; b \\
\hline $\begin{array}{l}\text { "Zeaglobigerina" ampliapertura (BOLli 1957) } \\
\text { * } 1957 \text { Globigerina ampliapertura - Bolli: 108; pl. 22, figs. 4a-c, 5a-c, 6a, b, 7a, b. }\end{array}$ & Plate 16, fig. 5a-c \\
\hline $\begin{array}{l}\text { Zeaglobigerina sp. } 1 \\
\quad 1994 \text { Zeaglobigerina sp. } 1 \text { - SPEZZAFERRI: 33; pl. 7, fig. 1a-c; pl. 8, fig. 3a-c. }\end{array}$ & Plate 16 , fig. $6 a-c$ \\
\hline
\end{tabular}




\section{Plate 1}

Bathysiphon taurinensis SACCO

sample Eguisheim-1, "Marnes à foraminiferes", early Late Rupelian (scale 500um), C39165

Fig. 1a lateral view

Fig. 1b apertural view

Hyperammina sp.

sample A-71, "Marnes à foraminifères”, early Late Rupelian (scale $100 \mu \mathrm{m})$, C39322

Fig. 2a lateral view

Fig. $2 b \quad$ apertural view

Rhizammina? sp.

sample W-70, “Marnes à foraminiferes”, early Late Rupelian (scale $500 \mu \mathrm{m})$, C39184

Fig. 3 lateral view

Lagenammina sp.

sample W-24, “Marnes à Cyrènes”, Late Rupelian (scale 100 m), C39297

Fig. 4a, b lateral views

Saccammina sphaerica BRADY

sample Eguisheim-1, "Marnes à foraminiferes”, early Late Rupelian (scale 500 m), C39167

Fig. 5a apertural view

Fig. 5b lateral view

Ammodiscus incertus (D'ORBIGNY)

sample Eguisheim-3, "Marnes à foraminiferes”, early Late Rupelian (scale $200 \mu \mathrm{m}$ ), C39288

Fig. 6a peripheral view

Fig. 6b spiral view

Repmanina charoides (JONES \& PARKER)

sample W-23, "Marnes à Cyrènes”, Late Rupelian (scale 100 um), C39296

Fig. 7a peripheral view

Fig. $7 \mathrm{~b}$ spiral view

sample W-68, "Marnes à foraminiferes”, early Late Rupelian (scale $100 \mu \mathrm{m}), \mathrm{C} 39130$

Fig. 8a peripheral view

Fig. 8b spiral view

Reophax scorpiurus Denys De Montfort

sample W-68, "Marnes à foraminifères", early Late Rupelian (scale $100 \mu \mathrm{m}), \mathrm{C} 39104$

Fig. 9 lateral view

Reophax subfusiformis EARLAND

sample W-73, "Marnes à foraminiferes”, early Late Rupelian (scale 300 m), C39302

Fig. 10a lateral view

Fig. 10b apertural view

Subreophax elongatus (GRZYBOwski)

sample A-66, "Marnes à foraminifères", early Late Rupelian (scale 500 m), C39309

Fig. $11 \mathrm{a}, \mathrm{b}$ lateral views

sample W-70, "Marnes à foraminifères", early Late Rupelian

Fig. 12 thin section (approx. to scale)

Ammobaculites agglutinans (D'ORBIGNY)

sample W-71, “Marnes à foraminiferes”, early Late Rupelian (scale $200 \mu \mathrm{m})$, C39174

Fig. 13a, b lateral views

sample W-70, "Marnes à foraminifères”, early Late Rupelian, C39349

Fig. 14 thin section (approx. to scale)

Ammobaculites? sp.

sample Eguisheim-1, "Marnes à foraminiferes”, early Late Rupelian (scale 100 um), C39200

Fig. 15a, b lateral views 


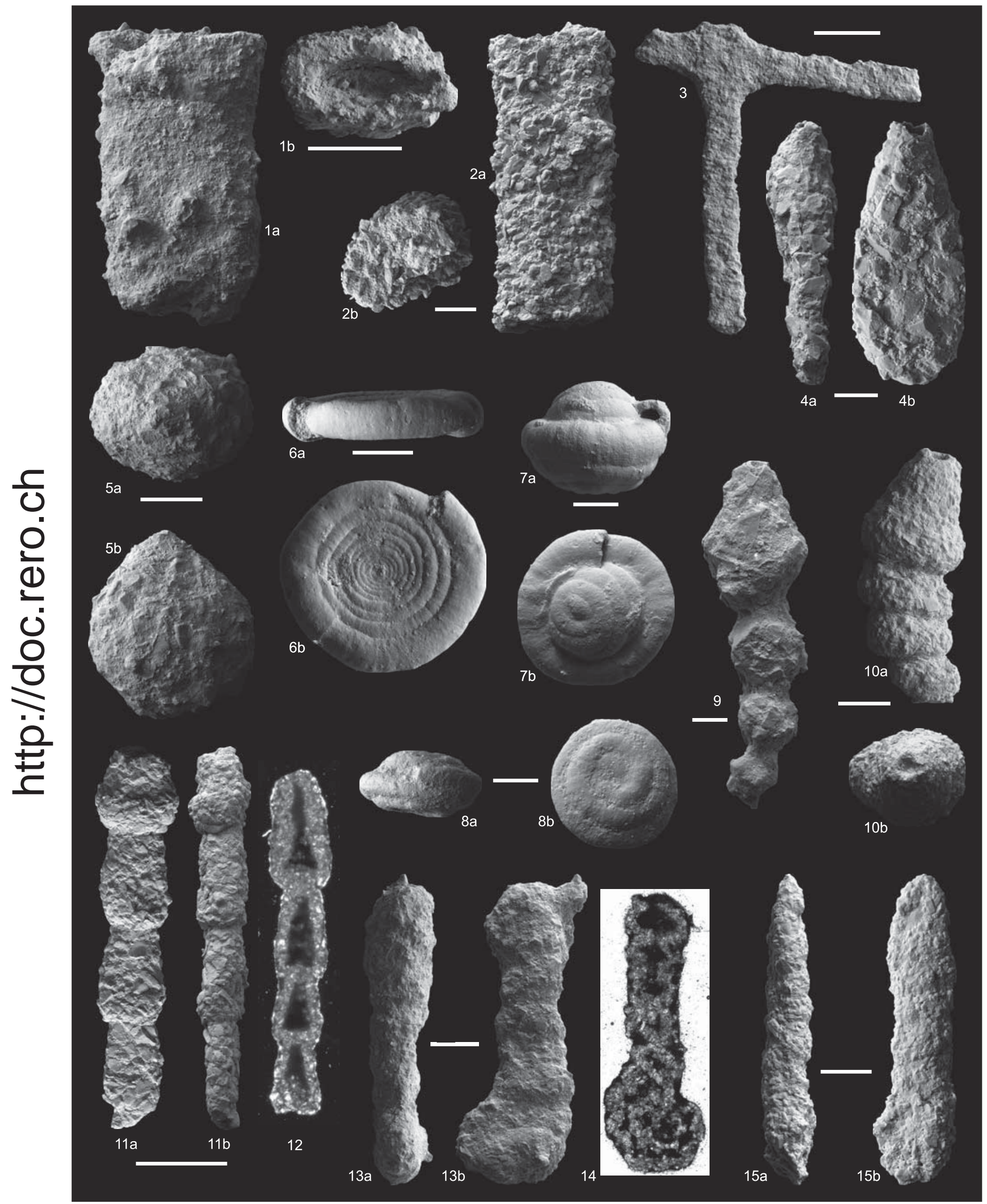




\section{Plate 2}

Sabellovoluta humboldti (REuss)

standard form, sample A-71, "Marnes à foraminifères", early Late Rupelian (scale $500 \mu \mathrm{m}$ ), C39323

Fig. 1a lateral view

Fig. 1b apertural view

triangular final chambers, sample W-72, "Marnes à foraminiferes", early Late Rupelian (scale $500 \mu \mathrm{m}$ ), C39300

Fig. 2a apertural view

Fig. 2b, c lateral views

sample W-75, "Marnes à foraminiferes", early Late Rupelian, C39350

Fig. 3 thin section (approx. to scale)

Reticulophragmium acutidorsatum (HANTKEN)

sample A-74a, "Marnes à foraminifères", early Late Rupelian (scale $500 \mu \mathrm{m}$ ), C39330

Fig. 4a peripheral view

Fig. 4b lateral view

sample W-76, "Marnes à foraminiferes", early Late Rupelian, C39351

Fig. 5 thin section (approx. to scale)

Reticulophragmium? acutidorsatum exigua (SCHRODT)

sample W-67, "Marnes à foraminiferes" - "Schistes à poissons" - transition, early Late Rupelian (scale $200 \mu \mathrm{m}$ ),

Fig. 6a lateral view

Fig. 6b peripheral view

Reticulophragmium rotundidorsatum (HANTKEN)

sample Eguisheim-3, "Marnes à foraminiferes", early Late Rupelian (scale $300 \mu \mathrm{m}$ ), C39287

Fig. 7a peripheral view

Fig. $7 \mathrm{~b}$ lateral view

sample W-73, "Marnes à foraminiferes", early Late Rupelian, C39352

Fig. 8 thin section (approx. to scale)

Spiroplectinella carinata D'ORBIGNY

microspheric form, sample DP-202 W-77, “Marnes à foraminiferes", early Late Rupelian (scale 300 um), C39176

Fig. 9a peripheral view

Fig. $9 \mathrm{~b}$ lateral view

Fig. 9c apertural view

microspheric form, sample A-67, "Marnes à foraminifères", early Late Rupelian, C39353

Fig. 11 thin section (approx. to scale)

macrospheric form, sample W-76, "Marnes à foraminiferes", early Late Rupelian (scale $300 \mu \mathrm{m}$ ), C39177

Fig. 10a peripheral view

Fig. 10b lateral view

Spiroplectinella deperdita (D'ORBIGNY)

sample Eguisheim-3, "Marnes à foraminiferres", early Late Rupelian (scale $200 \mu \mathrm{m}$ ), C39285

Fig. 12a lateral view

Fig. 12b peripheral view

Trochammina sp.

trochospiral form, sample W-68, "Marnes à foraminiferes", early Late Rupelian (scale $100 \mu \mathrm{m}$ ), C39285

Fig. 13a spiral view

Fig. 13b lateral view

Fig. 13c umbilical view 


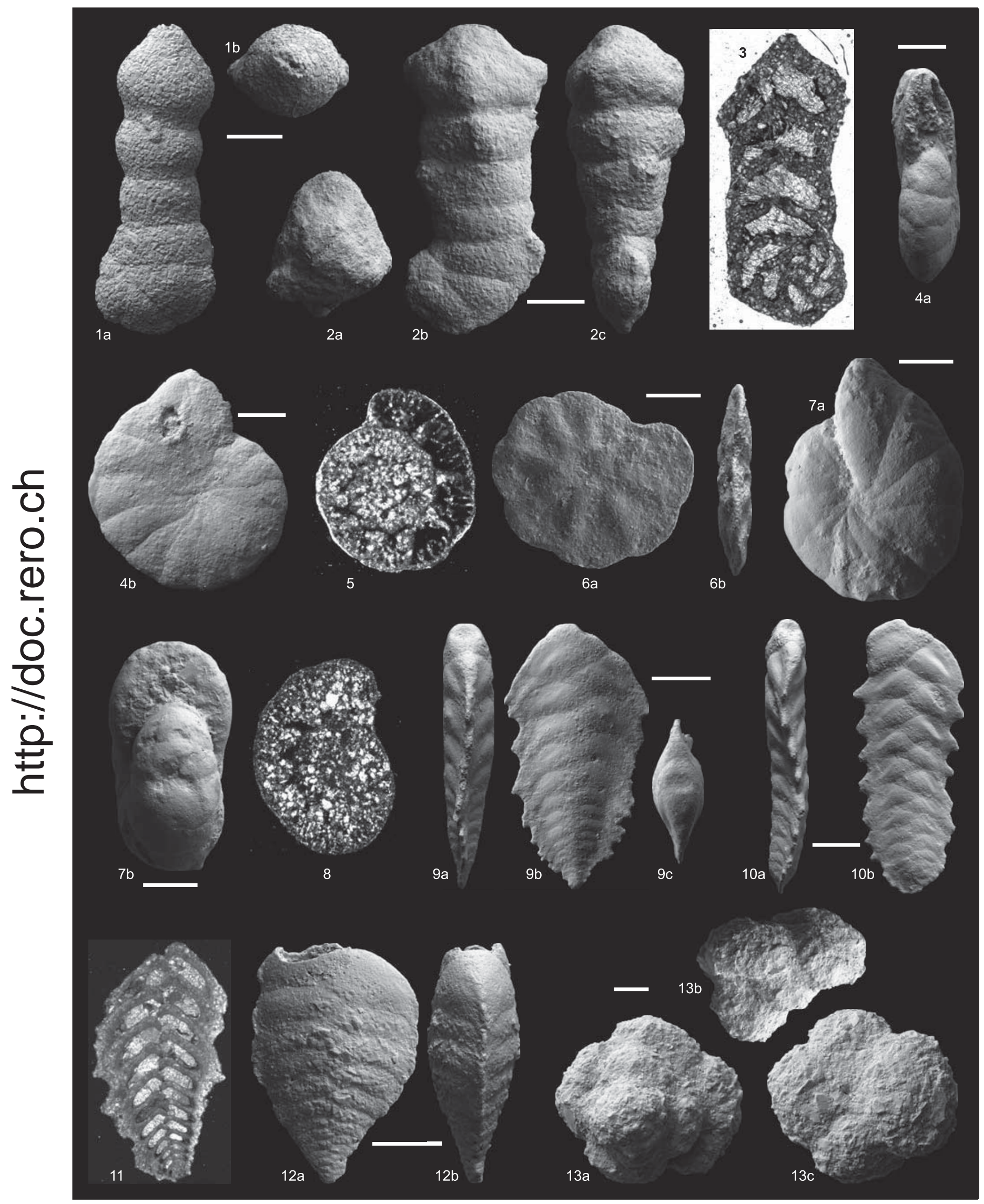




\section{Plate 3}

Trochammina cf. quadriloba (GRZYBOwsкI)

sample W-68, "Marnes à foraminiferes", early Late Rupelian (scale $200 \mu \mathrm{m}$ ), C39106

Fig. 1a spiral view

Fig. 1b peripheral view

Gaudrynopsis austriacus (RöGL)

sample W-67, "Marnes à foraminifères" - "Schistes à poissons" - transition, early Late Rupelian (scale $300 \mu \mathrm{m}$ ), C39280

Fig. 2a, b lateral views

Eggerella irregularis (HANTKEN)

sample A-66, "Marnes à foraminiferres", early Late Rupelian (scale $250 \mu \mathrm{m}$ ), C39308

Fig. 3a, b lateral views

Karreriella chilostoma (Reuss)

sample A-34, "Couches à Melettes", eate Rupelian (scale $100 \mu \mathrm{m}$ ), C39244

Fig. 4a detail, test completely agglutinated of coccoliths

Fig. $4 \mathrm{~b} \quad$ lateral view

Fig. 4c apertural view

sample A-68, "Marnes à foraminiferes", early Late Rupelian (scale $100 \mu \mathrm{m}$ ), C39314

Fig. 5a, c lateral views

Fig. $5 \mathrm{~b} \quad$ apertural view

Karreriella siphonella (REuss)

sample Eguisheim-1, "Marnes à foraminiferes", early Late Rupelian (scale $100 \mu \mathrm{m}$ ), C39163

Fig. 6a, b lateral views

sample A-70, "Marnes à foraminifères", early Late Rupelian, C39354

Fig. 7 thin section (approx. to scale)

Karreriella siphonella exilis (HAGN)

sample A-72, "Marnes à foraminiferes", early Late Rupelian (scale $500 \mu \mathrm{m}$ ), C39327

Fig. 8 lateral view

sample A-71, "Marnes à foraminifères", early Late Rupelian (scale $250 \mu \mathrm{m}$ ), C39324

Fig. 9 lateral view

sample W-77, "Marnes à foraminiferes", early Late Rupelian, C39355

Fig. 10 thin section (approx. to scale)

Bigenerina nodosaria acuta KLAEHN

sample W-69, "Marnes à foraminiferes”, early Late Rupelian (scale 100 um), C39109

Fig. 11a, b lateral views

Siphotextularia labiata (Reuss)

sample A-70, "Marnes à foraminiferes", early Late Rupelian (scale $250 \mu \mathrm{m}$ ), C39319

Fig. 12a, c lateral views

Fig. 12b apertural view

sample A-71,"Marnes à foraminifères”, early Late Rupelian, C39356

Fig. 13 thin section (approx. to scale)

sample Eguisheim-1, "Marnes à foraminiferes", early Late Rupelian, C39357

Fig. 14 thin section (approx. to scale)

Textularia sp.

sample W-70, “Marnes à foraminiferes”, early Late Rupelian (scale $200 \mu \mathrm{m}), \mathrm{C} 39185$

Fig. 15a apertural view

Fig. 15b, c lateral views 


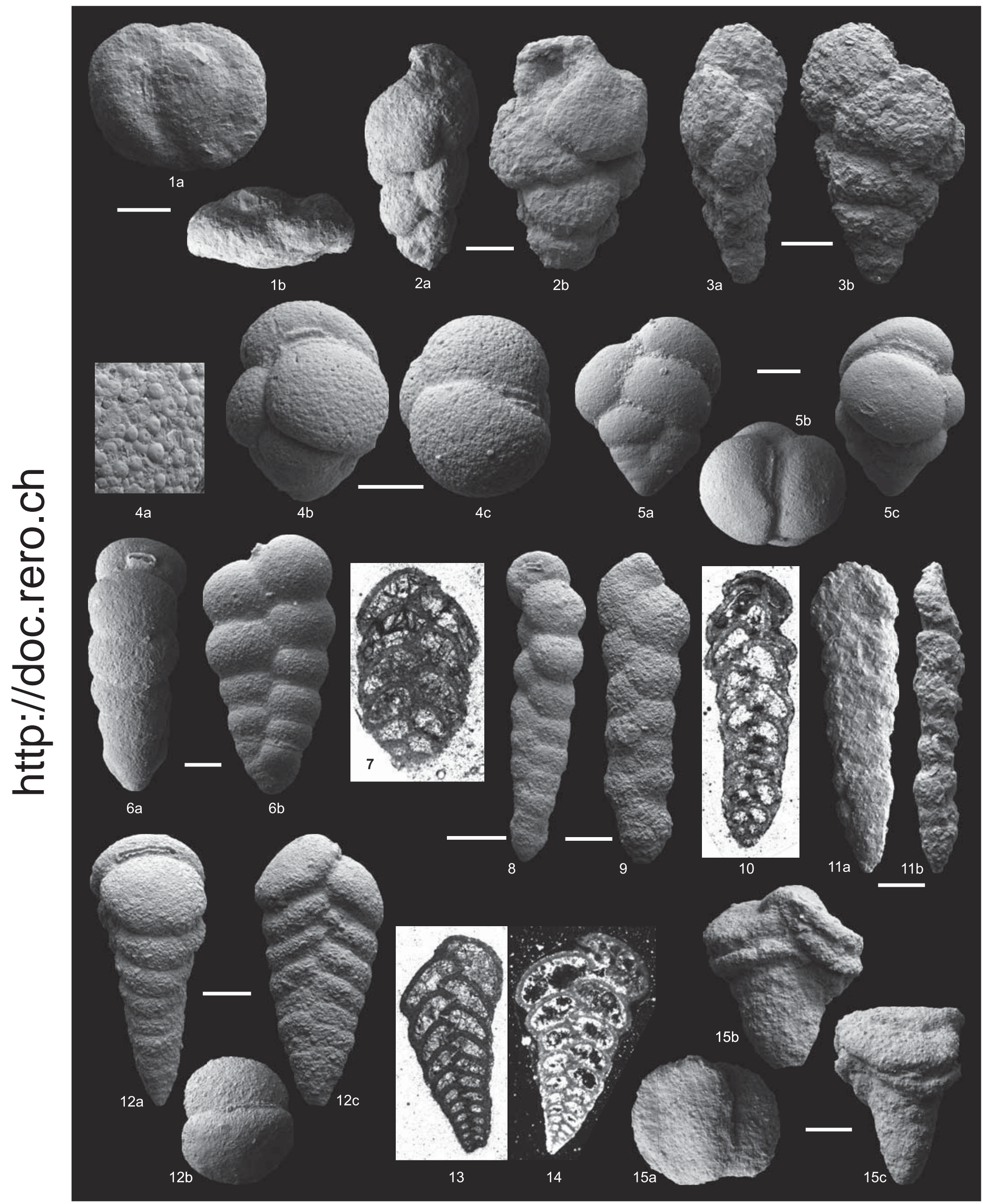




\section{Plate 4}

Spiroplectammina laevis cretosa (CUSHMAN)

sample W-75, "Marnes à foraminiferes”, early Late Rupelian, probably reworked Cretaceous (scale $300 \mu \mathrm{m}), \mathrm{C} 39230$

Fig. 1a lateral view

Fig. $1 \mathrm{~b} \quad$ apertural view

Fig. 1c peripheral view

Spiroloculina canaliculata D' ORBIGNY

sample W-72, "Marnes à foraminiferes", early Late Rupelian (scale $200 \mu \mathrm{m}$ ), C39301

Fig. 2a lateral view

Fig. $2 \mathrm{~b}$ apertural view

Fig. 2c peripheral view

Spiroloculina cf. excavata D'ORBIGNY

sample W-68, “Marnes à foraminiferes”, early Late Rupelian (scale 200 um), C39105

Fig. 3 lateral view

Cycloforina gracilis (KARRER)

sample A-15, "Marnes à Cyrènes”, Late Rupelian (scale $100 \mu \mathrm{m})$, C39342

Fig. $4 \mathrm{a}$ peripheral view

Fig. $4 \mathrm{~b} \quad$ lateral view

Fig. $4 \mathrm{c}$ apertural view

Cycloforina hauerina (D'ORBIGNY)

sample A-25, "Marnes à Cyrènes, Late Rupelian (scale 100 um), C39261

Fig. 5a lateral view

Fig. 5b peripheral view

Fig. 5c apertural view

Cycloforina ludwigi (REUss)

sample W-26, “Marnes à Cyrènes”, Late Rupelian (scale 200 m), C39298

Fig. 6a apertural view

Fig. $6 \mathrm{~b}$ lateral view

Quinqueloculina buchiana D' ORBIGNY

sample W-74, "Marnes à foraminiferes”, early Late Rupelian (scale 200 um), C39182

Fig. 7a, c lateral views

Fig. $7 \mathrm{~b}$ apertural view

Quinqueloculina gregaria ANDREAE

sample A-28, "Marnes à Cyrènes”, Late Rupelian (scale $200 \mu \mathrm{m}$ ), C39256

Fig. 8a lateral view

Fig. $8 \mathrm{~b} \quad$ apertural view

Quinqueloculinasp.

sample A-30, "Couches à Melettes" - "Marnes à Cyrènes" - transition, Late Rupelian (scale 100 m), C39254

Fig. 9a lateral view

Fig. 9b apertural view

Fig. 9c peripheral view

Flintina cf. variolaria CUVILlIER \& SZAKALL

sample A-152, lower “Zone fossilifère”, Earliest Rupelian (scale $100 \mu \mathrm{m}$ ), C39231

Fig. 10a lateral view

Fig. 10b apertural view

Pyrgoella globiformis (KARRER)

sample W-67, "Marnes à foraminiferes" - "Schistes à poissons" - transition, early Late Rupelian (scale $200 \mu \mathrm{m}$ ), C39281

Fig. 11a lateral view

Fig. $11 \mathrm{~b}$ apertural view

Triloculina gibba D’ORBIGNY

sample Eguisheim-1, "Marnes à foraminiferes”, early Late Rupelian (scale $100 \mu \mathrm{m})$, C39291

Fig. 12a lateral view

Fig. $12 b \quad$ peripheral view

Fig. 12c apertural view 


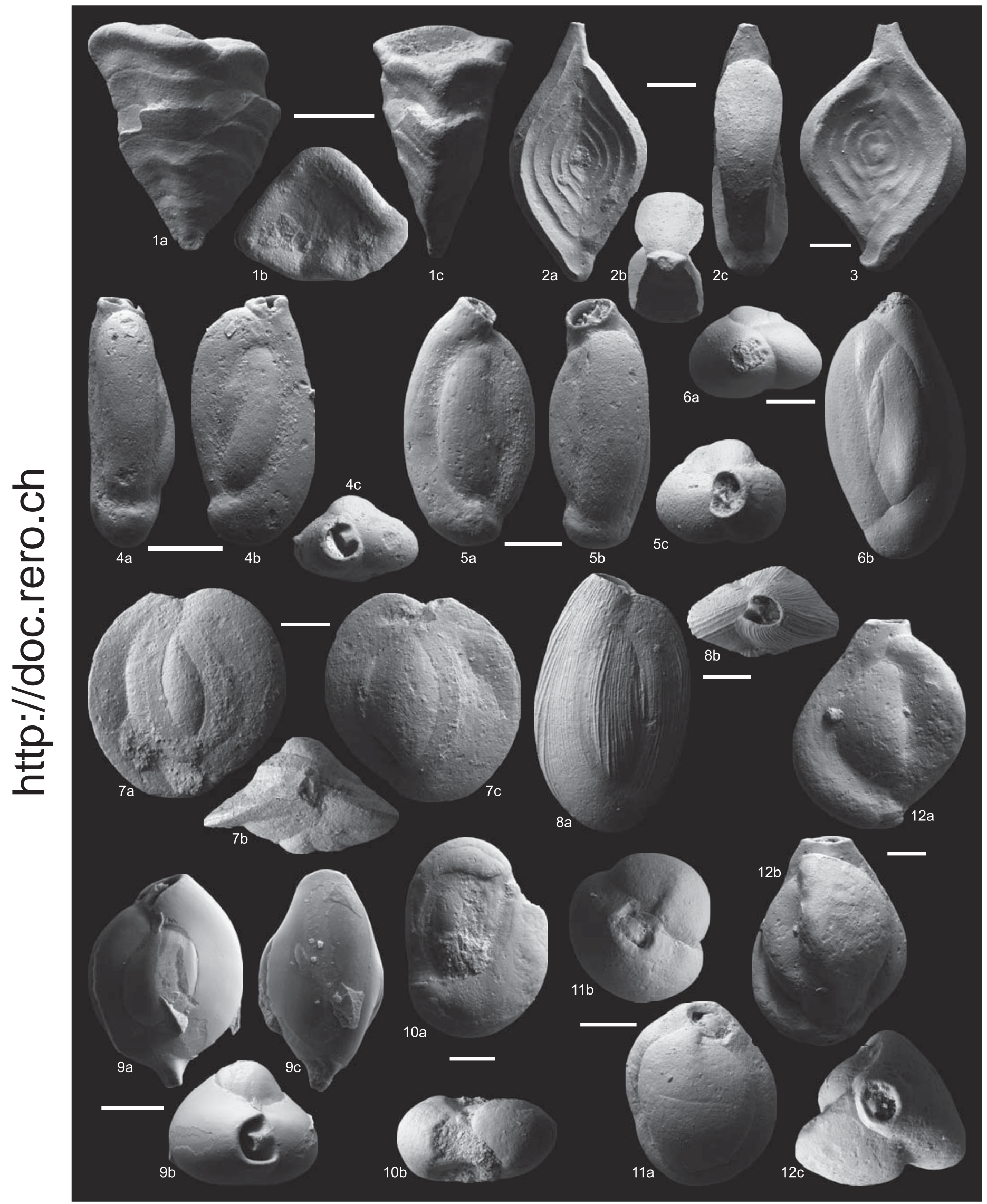




\section{Plate 5}

Sigmoilinita tenuis (CZJZEK)

sample A-15, “Marnes à Cyrènes”, Late Rupelian (scale 50 um), C39032

Fig. 1a lateral view

Fig. 1b peripheral view

Fig. 1c apertural view

Peneroplis? sp.

sample Retzwiller-2, “Marnes à Cyrènes”, Late Rupelian (scale $200 \mu \mathrm{m}$ ), C39306

Fig. 2 lateral view

Laevidentalina communis (D'ORBIGNY)

sample W-26, "Marnes à Cyrènes”, Late Rupelian (scale $200 \mu \mathrm{m}$ ), C39348

Fig. 3a lateral view

Fig. 3b apertural view

Laevidentalina elegans (D'ORBIGNY)

sample Eguisheim-2, "Marnes à foraminiferes", early Late Rupelian (scale 300 um), C39190

Fig. 4 lateral view

Nodosaria capitata striatissima ANDREAE

sample A-70, "Marnes à foraminiferes", early Late Rupelian (scale $300 \mu \mathrm{m}$ ), C39217

Fig. 5 lateral view

Nodosaria sp.

sample Eguisheim-1, "Marnes à foraminiferes", early Late Rupelian (scale $200 \mu \mathrm{m}$ ), C39294

Fig. 6a lateral view

Fig. $6 \mathrm{~b}$ apertural view

Nodosaria soluta ReUss

sample A-71, "Marnes à foraminiferes", early Late Rupelian (scale $200 \mu \mathrm{m}), \mathrm{C} 39210$

Fig. 7 lateral view

sample A-68, “Marnes à foraminifères", early Late Rupelian (scale $300 \mu \mathrm{m}$ ), C39222

Fig. 8 lateral view

Pyramidulina bactridium (REUss)

sample Eguisheim-1, "Marnes à foraminiferes”, early Late Rupelian (scale 500 m), C39164

Fig. 9 lateral view

Pyramidulina herrmanni (ANDREAE)

sample A-68, “Marnes à foraminifères”, early Late Rupelian (scale $200 \mu \mathrm{m}$ ), C39313

Fig. 10a lateral view

Fig. 10b apertural view

Pyramidulina ludwigi (Reuss)

sample A-72, "Marnes à foraminiferes", early Late Rupelian (scale $250 \mu \mathrm{m}$ ), C39325

Fig. 11a apertural view

Fig. $11 \mathrm{~b}$ lateral view

Frondicularia cf. oblonga (ROEMER)

sample Eguisheim-1, “Marnes à foraminiferes”, early Late Rupelian (scale 700 m), C39346

Fig. 12 lateral view

Lenticulina insignis (REuss)

sample A-71, "Marnes à foraminifères”, early Late Rupelian (scale $500 \mu \mathrm{m})$, C39031

Fig. 13a, c lateral views

Fig. 13b peripheral view

Lenticulina aff. reniformis (D'ORBIGNY)

sample Retzwiller-2, "Marnes à Cyrènes”, Late Rupelian (scale $300 \mu \mathrm{m})$, C39283

Fig. 14a, c lateral views

Fig. 14b peripheral view

Lenticulina sp. juv.

sample A-25, “Marnes à Cyrènes”, Late Rupelian (scale 200 um), C39260

Fig. 15a lateral view

Fig. 15b apertural view

Fig. 15c peripheral view

Marginulina hirsuta D'ORBIGNY

sample A-8a, "Marnes à Cyrènes" - "Molasse alsacienne" - transition, Latest Rupelian - Earliest Chattian (scale $100 \mu \mathrm{m}), \mathrm{C} 39148$

Fig. 16a lateral view

Fig. 16b apertural view

Marginulinopsis cf.jugleri (REUss)

sample A-72, "Marnes à foraminifères”, early Late Rupelian (scale $250 \mu \mathrm{m})$, C39326

Fig. 17a

peripheral view

Fig. 17b lateral view

Fig. 17c apertural view 


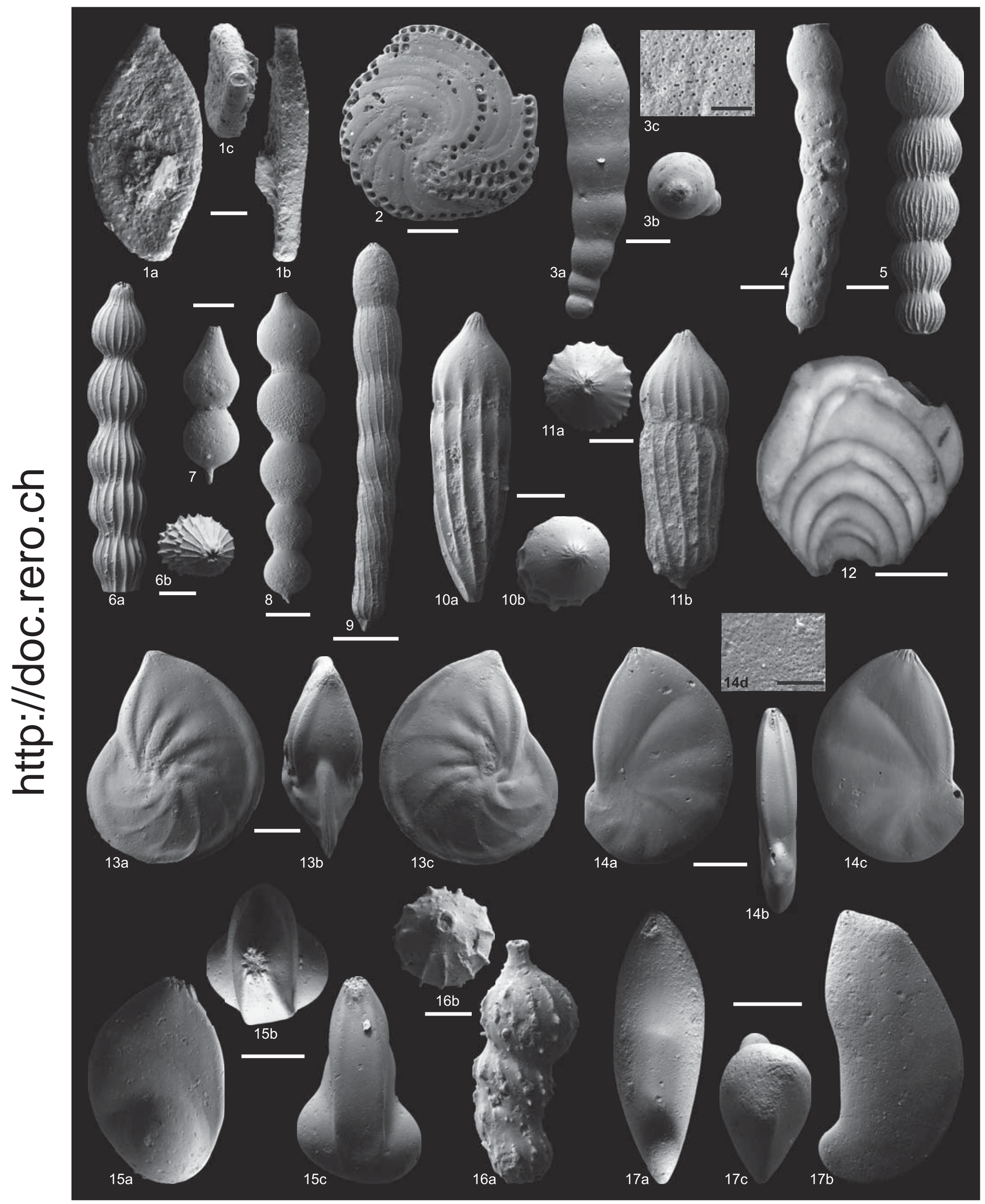




\section{Plate 6}

Planularia costata (Reuss)

sample A-66, "Marnes à foraminiferes", early Late Rupelian (scale $500 \mu \mathrm{m}$ ), C39028

Fig. 1a, c lateral views

Fig. $1 \mathrm{~b}$ peripheral view

sample A-70, "Marnes à foraminiferres", early Late Rupelian (scale $500 \mu \mathrm{m}$ ), C39030

Fig. 2a, c lateral views

Fig- $2 \mathrm{~b} \quad$ peripheral view

Pygmaeoseistron globosum (MONTAGU)

sample A-40, "Couches à Melettes", Late Rupelian (scale $50 \mu \mathrm{m}$ ), C39241

Fig. 3a lateral view

Fig. 3b apertural view

Pygmaeoseistron hispidum (Reuss)

sample A-31, "Couches à Melettes", Late Rupelian (scale $100 \mu \mathrm{m}$ ), C39253

Fig. 4a lateral view

Fig. 4b apertural view

Pygmaeoseistron rudis (Reuss)

sample A-70, "Marnes à foraminiferes", early Late Rupelian (scale $100 \mu \mathrm{m}$ ), C39220

Fig. 5a lateral view

Fig. $5 \mathrm{~b} \quad$ apertural view

Pygmaeoseistron vulgaris apiculatum (REUSS)

sample W-72, "Marnes à foraminiferes", early Late Rupelian (scale $50 \mu \mathrm{m}$ ), C39169

Fig. 6a lateral view

Fig. 6b apertural view

Lagena amphora REUSS

sample A-23, "Marnes á Cyrènes", Late Rupelian (scale 50 m), C39337

Fig. 7a lateral view

Fig. $7 \mathrm{~b}$ apertural view

Lagena gracilicosta ReUss

sample A-31, "Couches à Melettes", Late Rupelian (scale $50 \mu \mathrm{m}$ ), C39156

Fig. 8a lateral view

Fig. 8b apertural view

Lagena isabella isabella (D' ORBIGNY)

sample A-23, "Marnes á Cyrènes", Late Rupelian (scale 50 m), C39263

Fig. 9a lateral view

Fig. 9b apertural view

Lagena isabella conscripta (CUSHMAN \& BARKSDALE)

sample A-23, "Marnes á Cyrènes", Late Rupelian (scale 50 m), C39262

Fig. 10a lateral view

Fig. 10b apertural view

Lagena sulcata (WALTER \& JACOB)

sample A-23, "Marnes á Cyrènes", Late Rupelian (scale 50 m), C39151

Fig. 11a lateral view

Fig. 11b apertural view

Hyalinonetrion gracillimum (SEGUENZA)

sample Eguisheim-1, "Marnes à foraminiferes", early Late Rupelian (scale $100 \mu \mathrm{m}$ ), C39158

Fig. 12 lateral view

Globulina gibba D'ORBIGNY

sample A-68, "Marnes à foraminiferes", early Late Rupelian (scale $100 \mu \mathrm{m})$, C39315

Fig. 13a lateral view

Fig. 13b apertural view

Guttulina communis D' ORBIGNY

sample Retzwiller-2, "Marnes à Cyrènes", Late Rupelian (scale $300 \mu \mathrm{m}$ ), C39221

Fig. 14a lateral view

Fig. $14 \mathrm{~b}$ apertural view

Favulina hexagona (WiLLIAMSON)

sample A-68, "Marnes à foraminiferes", early Late Rupelian (scale $50 \mu \mathrm{m}$ ), C39223

Fig. 15a lateral view

Fig. 15b apertural view

Fig. $15 \mathrm{c}$ peripheral view

Fissurina orbignyana orbignyana (SEGUENZA)

sample A-8a, "Marnes à Cyrènes" - "Molasse alsacienne" - transition, Latest Rupelian - Earliest Chattian (scale 100 m), C39149

Fig. 16a lateral view

Fig. 16b apertural view 


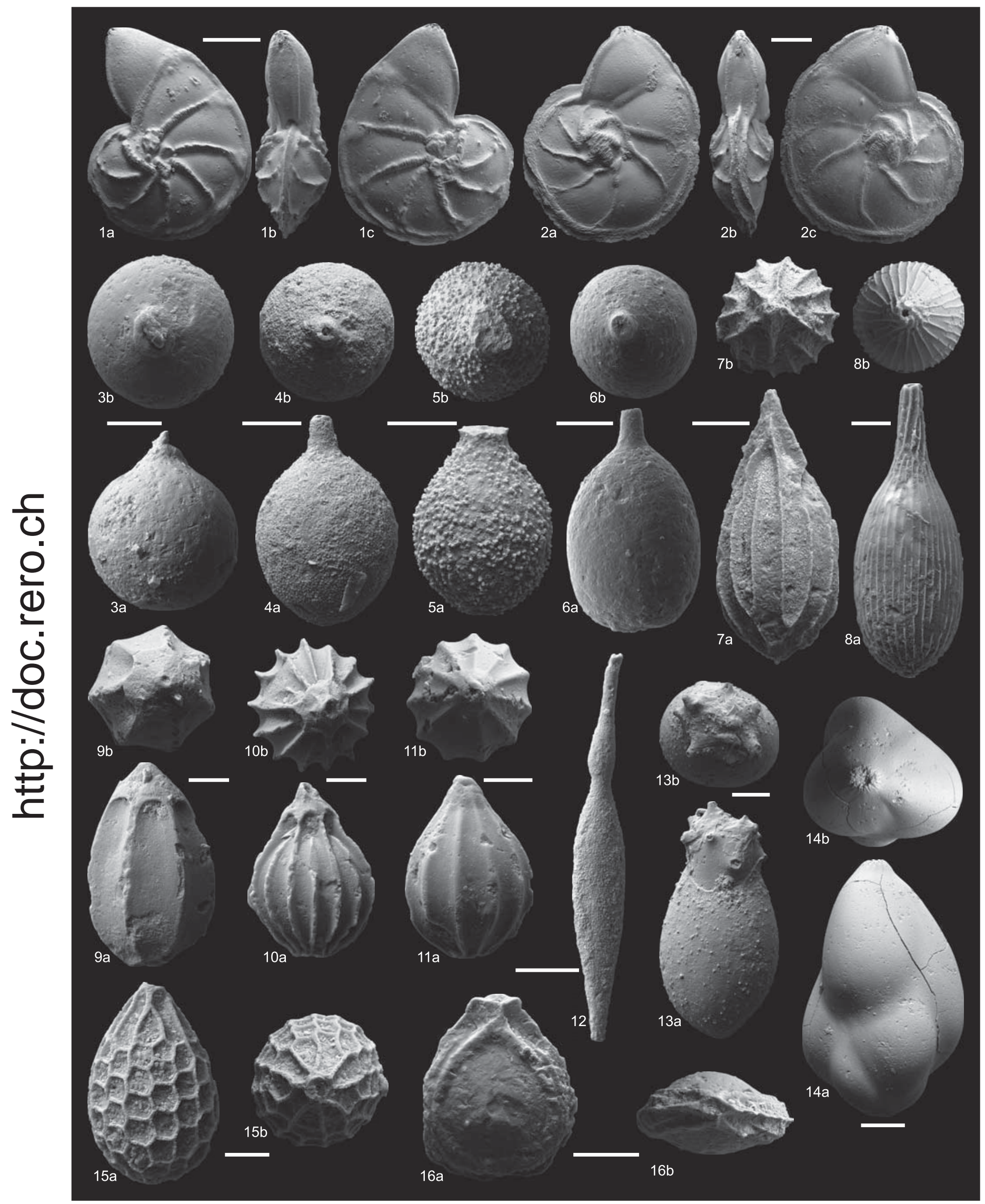




\section{Plate 7}

Fissurina orbignyana striata FRIESE

sample A-28, "Marnes à Cyrènes", Late Rupelian (scale $50 \mu \mathrm{m}$ ), C39153

Fig. 1a lateral view

Fig. 1b apertural view

"Siphopyrulina" fusiformis (ROEMER)

sample A-25, “Marnes à Cyrènes", Late Rupelian (scale $100 \mu \mathrm{m}$ ), C39257

Fig. 2 lateral view

Bolivina beyrichi (REUSs)

normal form, sample W-58, "Schistes à poissons", early Late Rupelian (scale $100 \mu \mathrm{m}$ ), C39171

Fig. 3a peripheral view

Fig. 3b lateral view

carinate form, sample W-61, "Schistes à poissons", early Late Rupelian (scale $100 \mu \mathrm{m}$ ), C39170

Fig. $4 a$ peripheral view

Fig. $4 \mathrm{~b}$ lateral view

Bolivina crenulata CUSHMAN

sample A-23, "Marnes à Cyrènes", Late Rupelian (scale 50 um), C39338, C39335

Fig. 5, 6a lateral views

Fig. 6b peripheral view

Bolivina cf. crenulata CUSHMAN

sample A-155, lower “Zone fossilifère”, Earliest Rupelian (scale 50 um), C39224

Fig. 7 lateral view

Bolivina elongata HANTKEN

sample A-66, "Marnes á foraminifères”, early Late Rupelian (scale $100 \mu \mathrm{m})$, C39311

Fig. 8a peripheral view

Fig. 8b lateral view

Bolivina melettica ANDREAE

sample A-31, "Couches à Melettes", Late Rupelian (scale 50 m), C39154

Fig. 9a peripheral view

Fig. 9b lateral view

Bolivina semistriata nobilis HANTKEN

sample Eguisheim-3, "Marnes á foraminifères”, early Late Rupelian (scale $50 \mu \mathrm{m}$ ), C39197

Fig. 10a peripheral view

Fig. 10b lateral view

Globocassidulina subglobosa (BRADY)

sample A-66, "Marnes á foraminiferes", early Late Rupelian (scale $50 \mu \mathrm{m}$ ), C39312

Fig. 11a lateral view

Fig. 11b peripheral view

Turrilina alsatica ANDREAE

sample A-59, "Couches à Melettes”, Late Rupelian (scale 50 m), C39235

Fig. 12a lateral view

Fig. $12 \mathrm{~b}$ apertural view

Praeglobobulimina coprolithoides (ANDREAE)

sample A-155, lower "Zone fossilifère”, Earliest Rupelian (scale $50 \mu \mathrm{m}$ ), C39225

Fig. 13a apertural view

Fig. 13b lateral view

Bulimina alsatica Cushman \& PARKer

sample Eguisheim-1, "Marnes à foraminiferes”, early Late Rupelian (scale 100 um), C39293

Fig. 14a lateral view

Fig. $14 \mathrm{~b}$ apertural view

sample W-68, "Marnes à foraminiferes”, early Late Rupelian (scale $100 \mu \mathrm{m})$, C39128

Fig. 15a apertural view

Fig. 15b lateral view

Bulimina sculptilis CushmaN

sample W-23, "Marnes à Cyrènes", Late Rupelian (scale $100 \mu \mathrm{m})$, C39303

Fig. 16a lateral view

Fig. 16b apertural view

sample Wessenberg-3, “Molasse alsacienne”, Early Chattian, reworked (scale $100 \mu \mathrm{m}$ ), C39146

Fig. 17 lateral view 


\section{Plate 8}

Uvigerina gracilis germanica CUSHMAN \& EDWARDS

sample A-70, "Marnes á foraminiferes", early Late Rupelian (scale $100 \mu \mathrm{m}$ ), C39218

Fig. 1a lateral view

Fig. 1b apertural view

sample A-71, "Marnes á foraminifères", early Late Rupelian (scale $100 \mu \mathrm{m}$ ), C39214

Fig. 2a lateral view

Fig. $2 \mathrm{~b}$ apertural view

sample Eguisheim-3, "Marnes á foraminiferes", early Late Rupelian (scale 50 m), C39204

Fig. 3a lateral view

Fig. 3b apertural view

Uvigerina cf. multistriata HANTKEN

sample A-8a, "Marnes à Cyrènes" - "Molasse alsacienne" - transition, Latest Rupelian - Earliest Chattian (scale 50 um), C39271

Fig. 4a lateral view

Fig. $4 \mathrm{~b} \quad$ apertural view

juvenile, sample W-45, “Couches à Melettes", Late Rupelian (scale $50 \mu \mathrm{m}$ ), C39277

Fig. 5a lateral view

Fig. $5 \mathrm{~b} \quad$ apertural view

Uvigerina rudlingensis PAPP

sample A-8a, "Marnes à Cyrènes" - "Molasse alsacienne" - transition, Latest Rupelian - Earliest Chattian (scale $50 \mu \mathrm{m}$ ), C39275

Fig. 6a lateral view

Fig. $6 \mathrm{~b}$ apertural view

Uvigerina rugosa D'ORBIGNY

sample W-23, "Marnes à Cyrènes", Late Rupelian (scale $100 \mu \mathrm{m}$ ), C39304

Fig. 7a lateral view

Fig. $7 \mathrm{~b}$ apertural view

Uvigerina tenuistriata Reuss

sample W-76, "Marnes á foraminiferes", early Late Rupelian (scale $100 \mu \mathrm{m})$, C39179

Fig. 8a lateral view

Fig. $8 \mathrm{~b} \quad$ apertural view

Uvigerina vicksburgensis CUSHMAN \& ELLISOR

sample W-28, "Couches à Melettes" - "Marnes à Cyrènes" - transition, Late Rupelian (scale $100 \mu \mathrm{m}$ ), C39276

Fig. 9a lateral view

Fig. $9 \mathrm{~b} \quad$ apertural view

Angulogerina cf. angulosa (Williamson)

sample A-23, "Marnes à Cyrènes", Late Rupelian (scale $100 \mu \mathrm{m}$ ), C39340

Fig. 10a lateral view

Fig. 10b apertural view

sample A-8a, "Marnes à Cyrènes" - "Molasse alsacienne" - transition, Latest Rupelian - Earliest Chattian (scale $100 \mu \mathrm{m})$, C39343

Fig. 11a lateral view

Fig. 11b apertural view

Angulogerina globosa (STOLTZ)

sample A-8a, "Marnes à Cyrènes" - "Molasse alsacienne" - transition, Latest Rupelian - Earliest Chattian (scale 50 um), C39344

Fig. 12a lateral view

Fig. 12b apertural view

Angulogerina muralis (TERQUEM)

sample A-23, "Marnes à Cyrènes", Late Rupelian (scale $100 \mu \mathrm{m}$ ), C39150

Fig. 13a lateral view

Fig. 13b apertural view

Angulogerina oligocenica (ANDREAE)

sample A-72, "Marnes à foraminiferes", early Late Rupelian (scale 50 um), C39329

Fig. 14a lateral view

Fig. 14b apertural view

Colomia sp.

sample A-23, "Marnes à Cyrènes", Late Rupelian, possibly reworked Cretaceous (scale $100 \mu \mathrm{m}$ ), C39339

Fig. 15a apertural view

Fig. 15b lateral view

Pleurostomella alternans SCHWAGER

sample A-23, "Marnes à Cyrènes", Late Rupelian (scale $100 \mu \mathrm{m}$ ), C39336

Fig. 16a, b lateral views 


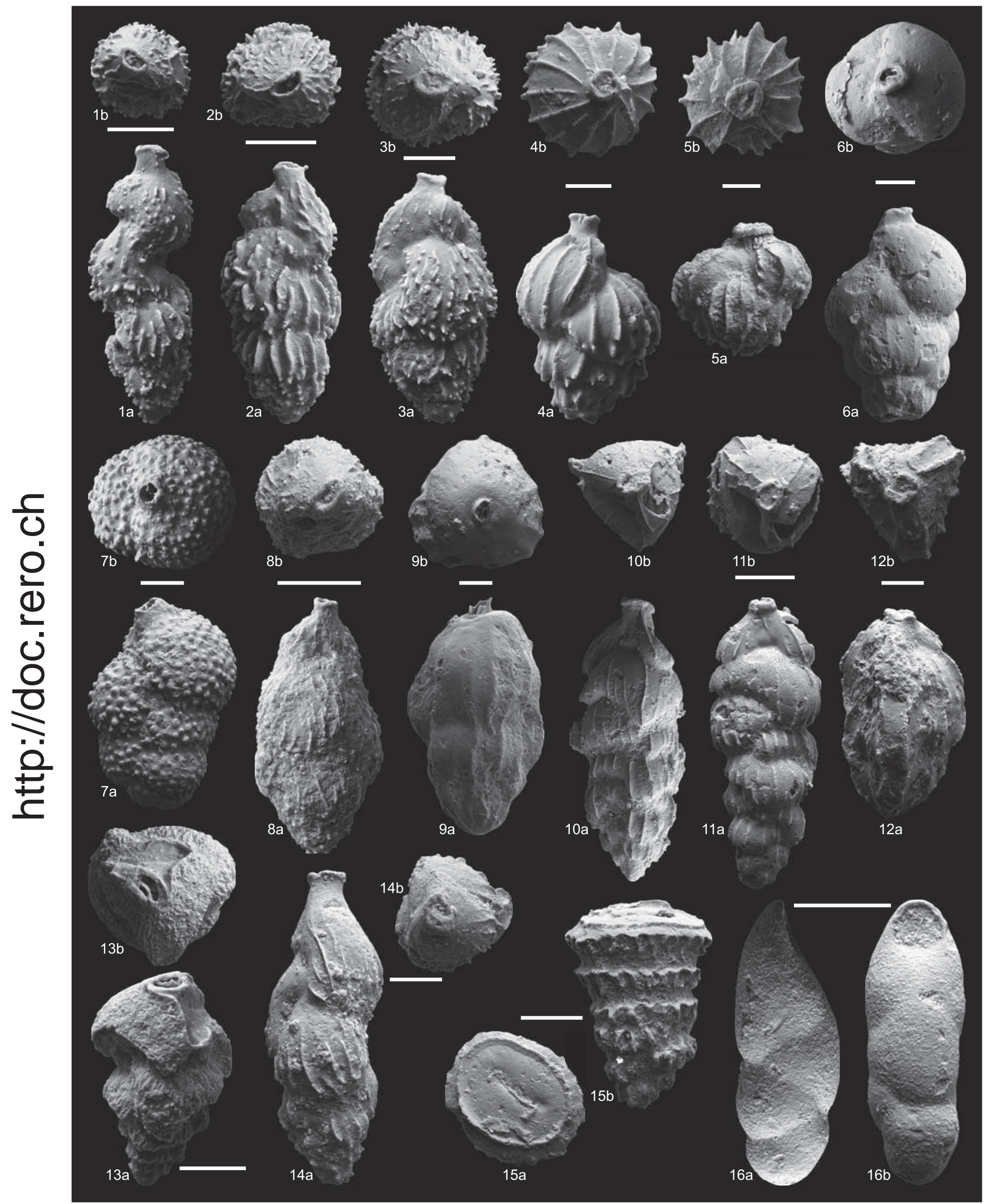




\section{Plate 9}

Siphonodosaria emaciata (REuss)

sample Eguisheim-1, "Marnes á foraminifères", early Late Rupelian (scale $50 \mu \mathrm{m}$ ), C39159

Fig. 1 lateral view

Siphonodosaria ewaldi (Reuss)

sample Eguisheim-1, "Marnes á foraminiferres", early Late Rupelian (scale $300 \mu \mathrm{m}$ ), C39295

Fig. 2 lateral view

Siphonodosaria adolphina (D'ORBIGNY)

sample W-20, "Marnes à Cyrènes", Late Rupelian (scale $100 \mu \mathrm{m}$ ), C39347

Fig. 3 lateral view

Cancris turgidus Cushman \& TODD

sample W-26, "Marnes à Cyrènes", Late Rupelian (scale $100 \mu \mathrm{m}$ ), C39079

Fig. 4a spiral view

Fig. 4b umbilical view

Fig. 4c lateral view

Sphaeroidina variabilis Reuss

sample A-68, "Marnes á foraminiferes", early Late Rupelian (scale $100 \mu \mathrm{m}$ ), C39318, C39316

Fig. 5a apertural view

Fig. $5 \mathrm{~b}$ lateral view

Fig. 6a spiral view

Fig. 6b oblique apertural view

Discorbinoides sp.

sample W-26, "Marnes à Cyrènes", Late Rupelian (scale $100 \mu \mathrm{m}$ ), C39077

Fig. 7a spiral view

Fig. $7 \mathrm{~b}$ umbilical view

Fig. $7 \mathrm{c}$ lateral view

Glabratella sp.

sample A-8a, "Marnes à Cyrènes" - "Molasse alsacienne" - transition, Latest Rupelian - Earliest Chattian (scale 50 um), C39274

Fig. 8a lateral view

Fig. $8 \mathrm{~b} \quad$ spiral view

Fig. 8c umbilical view

Cibicidoides lucidus (REuss)

sample A-72, "Marnes à foraminiferres", early Late Rupelian (scale $100 \mu \mathrm{m})$, C39328

Fig. 9a spiral view

Fig. $9 \mathrm{~b}$ umbilical view

Fig. 9c lateral view

Cibicidoides oligocenicus (Samoylova)

sample A-66, "Marnes à foraminiferes", early Late Rupelian (scale $100 \mu \mathrm{m}$ ), C39310

Fig. 10a spiral view

Fig. 10b umbilical view

Fig. 10c lateral view

Cibicidoides roemeri (Reuss)

sample A-66, "Marnes à foraminiferes", early Late Rupelian (scale $250 \mu \mathrm{m}$ ), C39307

Fig. 11a spiral view

Fig. 11b umbilical view

Fig. 11c lateral view 


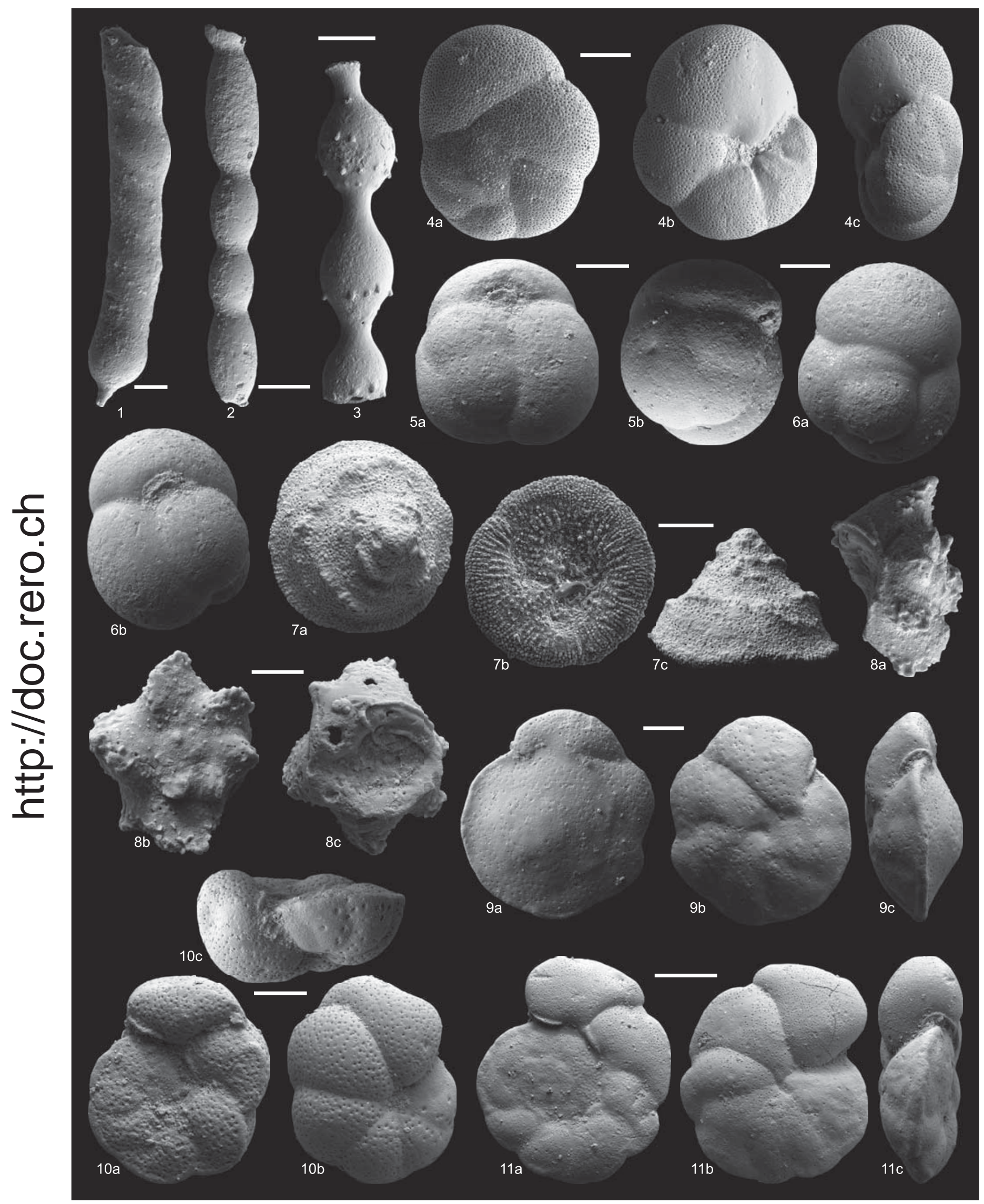




\section{Plate 10}

Cibicidoides? weinkauff (REuss)

sample A-70, “Marnes à foraminifères”, early Late Rupelian (scale $250 \mu \mathrm{m}$ ), C39321

Fig. 1a spiral view

Fig. 1b umbilical view

Fig. 1c lateral view

Cibicides amphisyliensis (ANDREAE)

sample W-59, “Marnes á foraminiferes”, early Late Rupelian (scale $100 \mu \mathrm{m})$, C39172

Fig. 2a spiral view

Fig. $2 \mathrm{~b} \quad$ lateral view

Planorbulina difformis ROEMER

sample Rheinweiler RWL 2-29, "Schistes à poissons", early Late Rupelian (scale $200 \mu \mathrm{m}$ )

Fig. 3a "spiral" view

Fig. $3 b$ "umbilical” view

Porosononion sp.

sample A-152, lower “Zone fossilifere”, Earliest Rupelian (scale $100 \mu \mathrm{m})$, C39232

Fig. $4 a, b \quad$ spiral views

Fig. $4 \mathrm{~b} \quad$ lateral view

Melonis affinis (REUSs)

sample Eguisheim-3, “Marnes á foraminiferes”, early Late Rupelian (scale 100 m), C39192

Fig. 5a, b spiral views

Fig. 5c lateral view

Pullenia bulloides (D'ORBIGNy)

sample W-70, "Marnes á foraminiferes", early Late Rupelian (scale $100 \mu \mathrm{m})$, C39188

Fig. 6a spiral view

Fig. 6b lateral view

Pullenia quinqueloba (REuss)

sample Eguisheim-1, “Marnes á foraminiferres”, early Late Rupelian (scale 100 m), C39209

Fig. 7a spiral view

Fig. $7 \mathrm{~b} \quad$ lateral view

Almaena osnabrugensis (RoEMER)

sample Wessenberg-3, "Molasse alsacienne", early Chattian, reworked Paleogene (scale $100 \mu \mathrm{m}$ ), C39145

Fig. 8a spiral view

Fig. $8 \mathrm{~b} \quad$ lateral view

Suratkina perlata (ANDREAE)

sample Eguisheim-3, "Marnes á foraminiferes”, early Late Rupelian (scale 100 um), C39193

Fig. 9a spiral view

Fig. 9b umbilical view

Fig. 9c lateral view

Heterolepa dutemplei (D'ORBIGNY)

sample A-68, “Marnes à foraminiferes”, early Late Rupelian (scale $100 \mu \mathrm{m})$, C39317

Fig. 10a spiral view

Fig. 10b umbilical view

Fig. 10c lateral view 


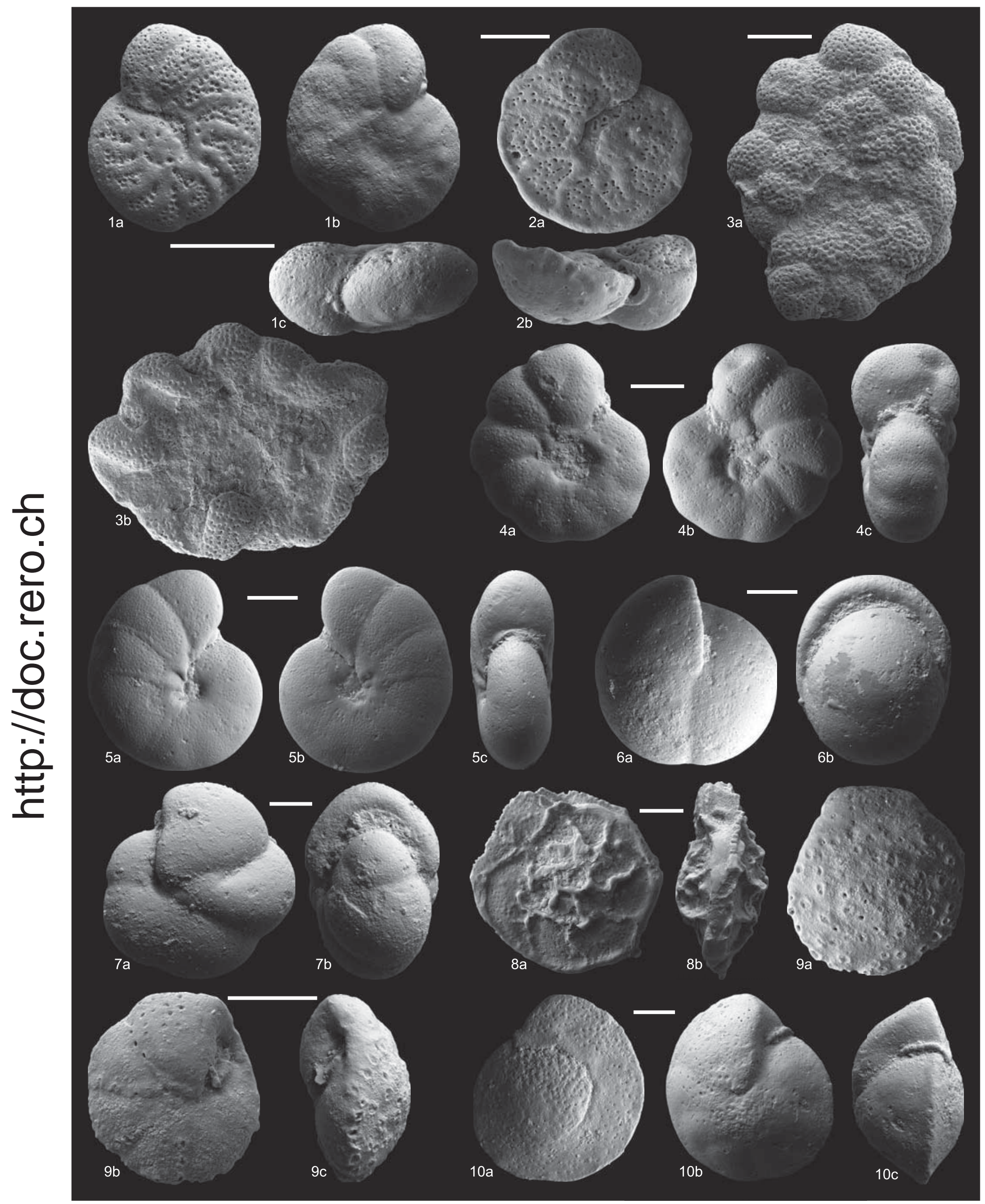




\section{Plate 11}

Gyroidina brokerti REISER

sample A-64, "Schistes à poissons", early Late Rupelian (scale $100 \mu \mathrm{m}), \mathrm{C} 39233$

Fig. 1a spiral view

Fig. $1 b \quad$ umbilical view

Fig. 1c lateral view

Gyroidinoides girardanus (REUss)

sample A-70, "Marnes á foraminifères", early Late Rupelian (scale $250 \mu \mathrm{m}$ ), C39320

Fig. 2a spiral view

Fig. $2 b \quad$ umbilical view

Fig. 2c lateral view

Gyroidinoides mamillatus (ANDREAE)

sample W-67, "Marnes á foraminifères" - "Shistes à poissons" - transition, early Late Rupelian (scale 100 um), C39279

Fig. 3a spiral view

Fig. $3 \mathrm{~b}$ umbilical view

Fig. 3c lateral view

Hansenisca soldanii (D'ORBIGNY)

sample Eguisheim-3, “Marnes á foraminiferes”, early Late Rupelian (scale 100 m), C39290

Fig. $4 \mathrm{a}$ spiral view

Fig. 4b umbilical view

Fig. 4c lateral view

Aubignyna kiliani (ANDREAE)

sample W-26, "Marnes á Cyrènes", Late Rupelian (scale $100 \mu \mathrm{m})$, C39078

Fig. $5 \mathrm{a}$ spiral view

Fig. 5 b umbilical view

Fig. 5c lateral view

Buccella granulata (LAUTENSCHLAEGER)

sample W-70, "Marnes á foraminiferes", early Late Rupelian (scale $100 \mu \mathrm{m})$, C39252

Fig. 6a spiral view

Fig. 6b umbilical view

Fig. 6c lateral view

Pararotalia cf. canui rhenana (ELLERMANN)

sample A-59, "Schistes à poissons", early Late Rupelian (scale 100 um), C39234

Fig. 7a spiral view

Fig. $7 \mathrm{~b}$ umbilical view

Fig. $7 \mathrm{c}$ lateral view

Pararotalia cf. canui (CUSHMAN)

sample A-27, "Marnes á Cyrènes”, Late Rupelian (scale 100 m), C39259

Fig. 8a spiral view

Fig. 8 b umbilical view

Fig. 8c lateral view

Pararotalia canui (Cushman)

sample W-26, "Marnes á Cyrènes”, Late Rupelian (scale 100 m), C39072

Fig. 9a spiral view

Fig. 9b umbilical view

Fig. 9c lateral view

Elphidiella minuta (REuss)

sample A-26, "Marnes á Cyrènes”, Late Rupelian (scale 50 m), C39334

Fig. 10a lateral view

Fig. 10b spiral view 


\section{Plate 12}

Reworked Cretaceous planktonic Foraminifera

Heterohelix globulosa (EHRENBERG)

sample A-51, "Couches à Melettes”, Late Rupelian (scale $100 \mu \mathrm{m}$ ), C39047

Fig. 1a apertural view

Fig. 1b lateral view

Heterohelix striata (EHRENBERG)

sample A-8a, "Marnes à Cyrènes" - "Molasse alsacienne" - transition, Latest Rupelian - Earliest Chattian (scale $50 \mu \mathrm{m}), \mathrm{C} 39273$

Fig. 2a apertural view

Fig. $2 \mathrm{~b} \quad$ lateral view

Guembelitria sp.

sample A-23, "Marnes á Cyrènes”, Late Rupelian (scale 50 m), C39152

Fig. 3 lateral view

Muricohedbergella delrioensis (CARSEY)

sample W-20, “Marnes á Cyrènes”, Late Rupelian (scale 100 m), C39057

Fig. $4 \mathrm{a}$ spiral view

Fig. $4 \mathrm{~b} \quad$ umbilical view

Fig. 4c lateral view

Globotruncana linneiana (D'ORBIGNY)

sample W-20, "Marnes á Cyrènes", Late Rupelian (scale 100 m), C39063

Fig. 5a spiral view

Fig. $5 b \quad$ umbilical view

Fig. 5c lateral view

Globotruncana arca? (CUSHMAN)

sample A-51, “Couches à Melettes", Late Rupelian (scale $100 \mu \mathrm{m}$ ), C39046

Fig. 6a spiral view

Fig. $6 \mathrm{~b}$ umbilical view

Fig. 6c lateral view

Globotruncanella sp.

sample Retzwiller sandig, "Marnes á Cyrènes”, Late Rupelian (scale 100 m), C39136

Fig. 7a spiral view

Fig. $7 \mathrm{~b}$ umbilical view

Fig. 7c lateral view

Marginotruncana pseudolinneiana Pessagno

sample Retzwiller-2, “Marnes á Cyrènes”, Late Rupelian (scale $100 \mu \mathrm{m})$, C39134

Fig. 8a spiral view

Fig. 8 b umbilical view

Fig. 8c lateral view

sample Retzwiller sandig, "Marnes á Cyrènes”, Late Rupelian (scale 100 um), C39140

Fig. 9a umbilical view

Fig. 9b lateral view

Praeglobotruncana delrioensis (Plummer)

sample A-51, "Couches à Melettes", Late Rupelian (scale $100 \mu \mathrm{m}$ ), C39051

Fig. 10a umbilical view

Fig. 10b spiral view

Fig. 10c lateral view 


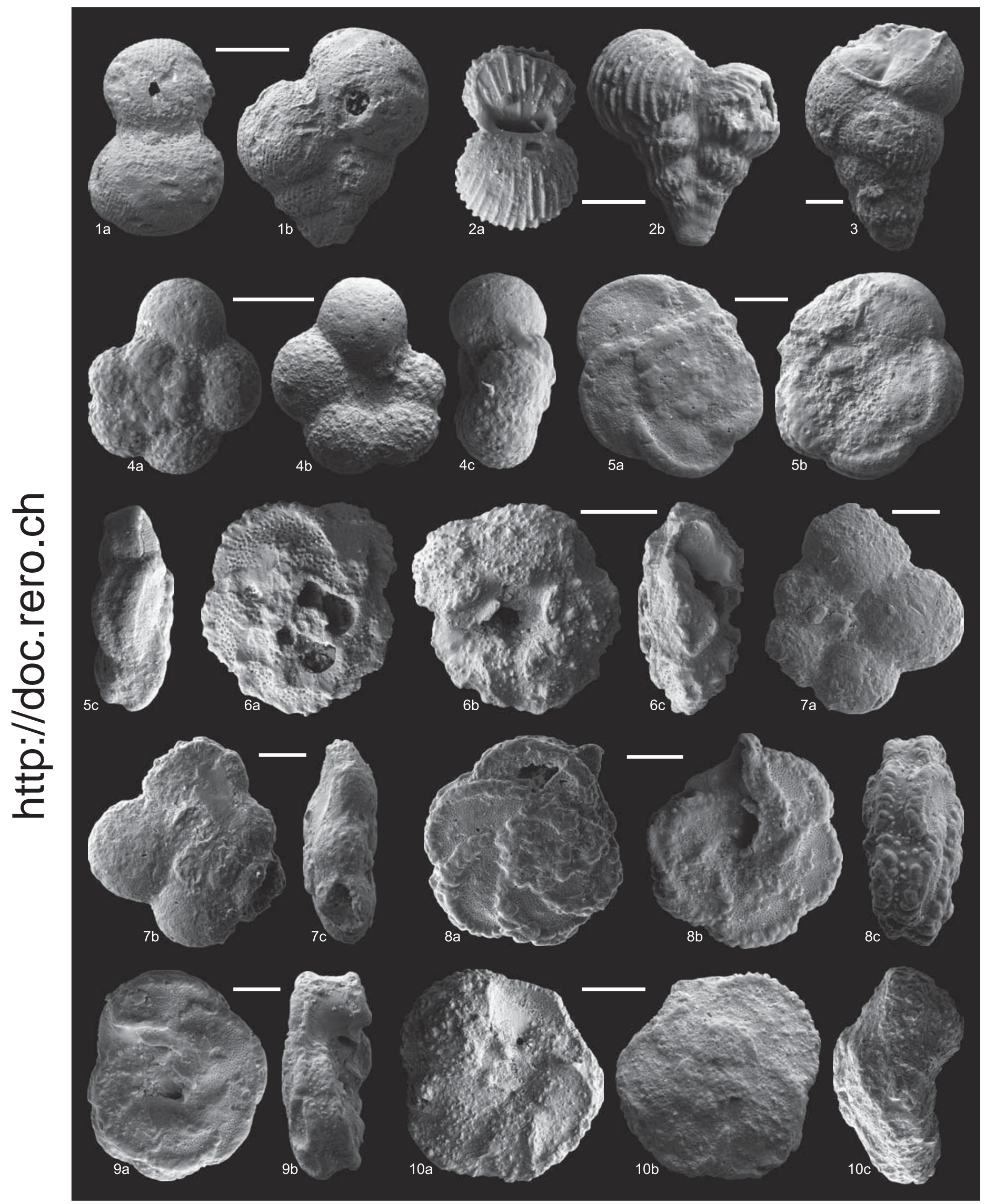




\section{Plate 13}

Reworked Cretaceous planktonic Foraminifera - Figs. 1-3

Reworked Eocene planktonic Foraminifera - Figs. 4-8

Contusotruncana fornicata (PLUMMER)

sample W-20, “Marnes á Cyrènes”, Late Rupelian (scale 100 m), C39115

Fig. 1a spiral view

Fig. $1 b \quad$ umbilical view

Fig. 1c lateral view

Rotalipora brotzeni (SIGAL)

sample Wessenberg-3, "Molasse alsacienne", Early Chattian (scale $100 \mu \mathrm{m})$, C39144

Fig. 2a spiral view

Fig. $2 b \quad$ lateral view

Fig. 2c umbilical view

Macroglobigerellinoides ultramicrus (SuввотіNA)

sample A-39, "Couches à Melettes", Late Rupelian (scale $100 \mu \mathrm{m})$, C39157

Fig. 3a spiral view

Fig. 3b umbilical view

Fig. 3c lateral view

Acarinina bullbrooki (BOLLI)

sample A-39, "Couches à Melettes", Late Rupelian (scale $100 \mu \mathrm{m})$, C39044

Fig. $4 \mathrm{a}$ spiral view

Fig. $4 \mathrm{~b}$ umbilical view

Fig. 4c lateral view

Acarinina collactea (FINLAY)

sample A-23, "Marnes á Cyrènes”, Late Rupelian (scale 50 m), C39040

Fig. 5a spiral view

Fig. $5 b \quad$ lateral view

Fig. 5c umbilical view

Acarinina decepta (MARTIN)

sample W-35, "Couches à Melettes”, Late Rupelian (scale $50 \mu \mathrm{m})$, C39124

Fig. 6a spiral view

Fig. 6b umbilical view

Fig. 6c lateral view

Acarinina matthewsae (BLOw)

sample W-20, "Marnes á Cyrènes”, Late Rupelian (scale $100 \mu \mathrm{m}$ ), C39053

Fig. 7 a spiral view

Fig. $7 \mathrm{~b}$ umbilical view

Fig. 7c lateral view

Acarinina medizzai (Toumarkine \& Bolli)

sample A-51, "Couches à Melettes”, Late Rupelian (scale 50 um), C39238

Fig. 8a spiral view

Fig. 8b umbilical view

Fig. 8c lateral view 


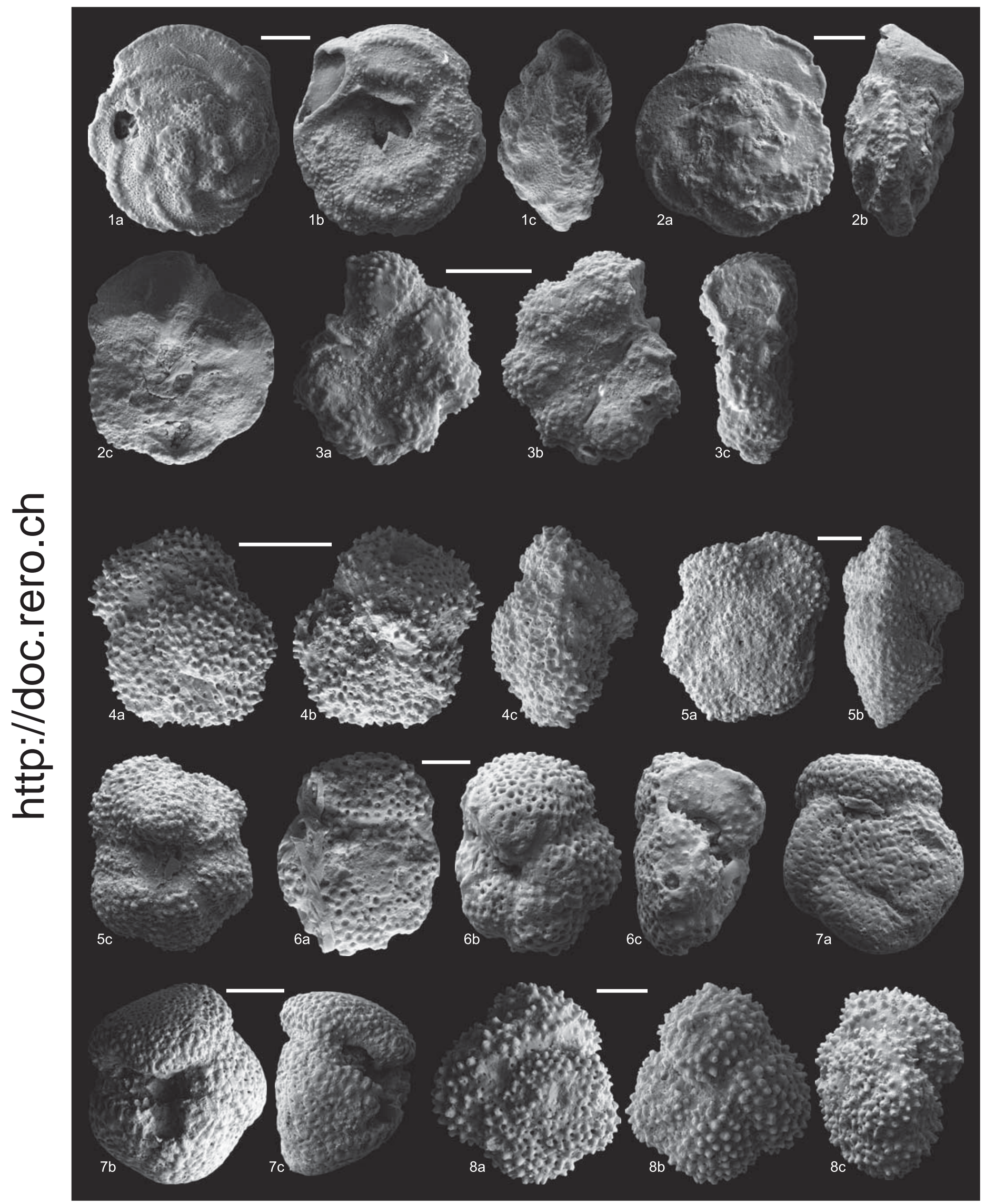




\section{Plate 14}

Reworked Eocene planktonic Foraminifera

Acarinina pentacamerata (SubBotina)

sample A-03, "Molasse alsacienne", Early Chattian (scale $50 \mu \mathrm{m}$ ), C39036

Fig. 1a spiral view

Fig. 1b umbilical view

Fig. 1c lateral view

Acarinina primitiva (FINLAY)

sample A-34, "Couches à Melettes", Late Rupelian (scale 50 m), C39247

Fig. 2a spiral view

Fig. $2 b \quad$ lateral view

Fig. 2c umbilical view

Acarinina pseudotopilensis (SubBotina)

sample A-51, "Couches à Melettes", Late Rupelian (scale $100 \mu \mathrm{m})$, C39045

Fig. 3a spiral view

Fig. 3b umbilical view

Acarinina rugosoaculeata (SUbBotina)

sample A-39, "Couches à Melettes", Late Rupelian (scale $100 \mu \mathrm{m}$ ), C39043

Fig. $4 \mathrm{a}$ spiral view

Fig. 4b umbilical view

Fig. 4c lateral view

Turborotalia cocoaensis (CUSHMAN)

sample A-39, "Couches à Melettes", Late Rupelian (scale $100 \mu \mathrm{m})$, C39333

Fig. 5 a spiral view

Fig. $5 \mathrm{~b} \quad$ lateral view

Fig. 5c umbilical view

Turborotalia frontosa (MARTIN)

sample W-18, uppermost "Marnes á Cyrènes", Latest Rupelian (scale 100 um), C39112

Fig. 6a spiral view

Fig. 6b umbilical view

Fig. 6c lateral view

Turborotalia possagnoensis (TOUMARKINE \& BOLLI)

sample Retzwiller sandig, "Marnes á Cyrènes”, Late Rupelian (scale $100 \mu \mathrm{m}$ ), C39138

Fig. 7a spiral view

Fig. $7 \mathrm{~b}$ umbilical view

Fig. 7c lateral view

Morozovella lehneri (Cushman \& JARVis)

sample Retzwiller-1, "Marnes á Cyrènes", Late Rupelian (scale 100 um), C39141

Fig. $8 \mathrm{a}$ spiral view

Fig. 8 b umbilical view

Fig. 8c lateral view 


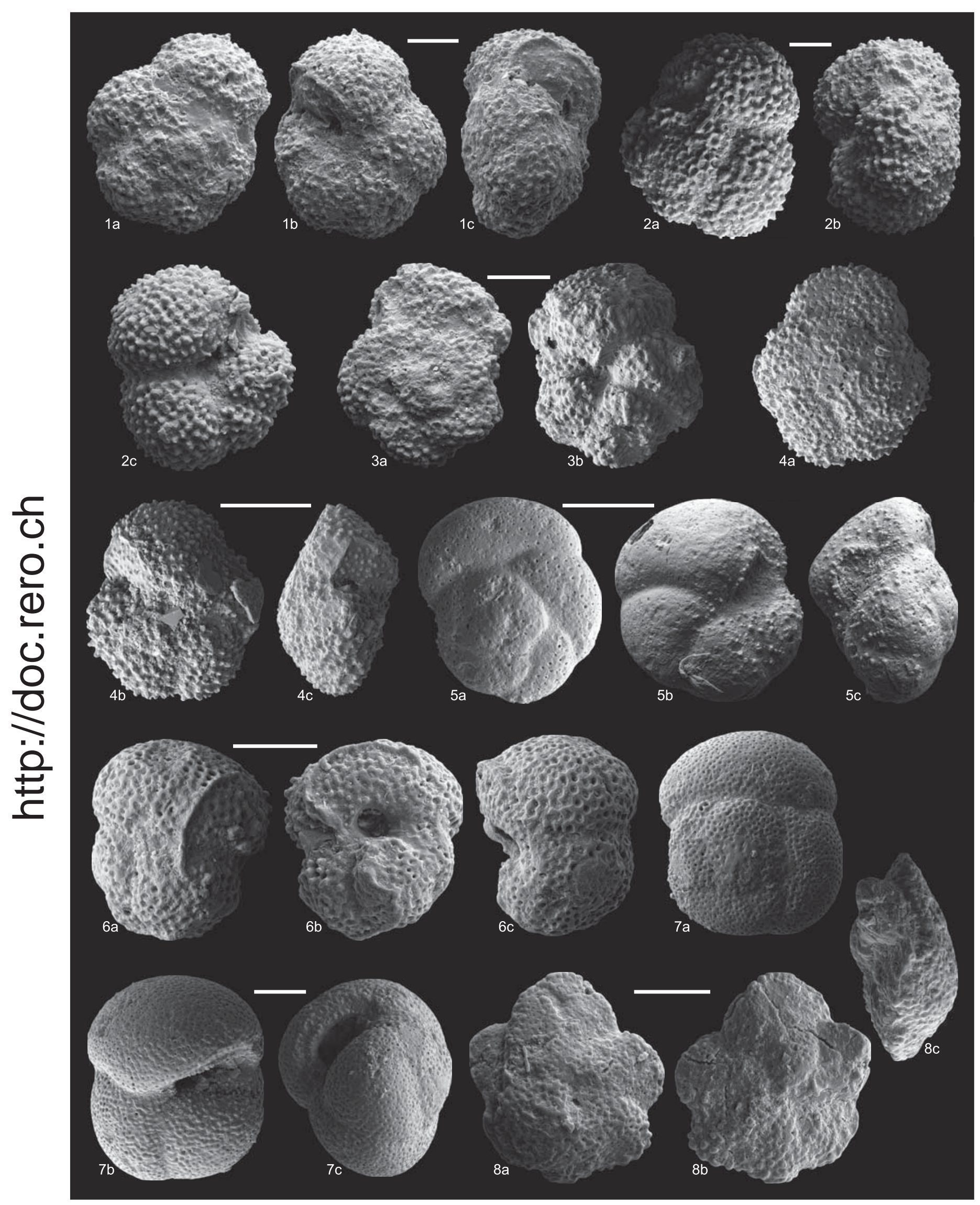




\section{Plate 15}

Reworked Eocene planktonic Foraminifera - Figs. 1-6

Eo-Oligocene planktonic Foraminifera - Figs. 7-10

Morozovella subbotinae (Morozova)

sample Retzwiller sandig, "Marnes á Cyrènes", Late Rupelian (scale 100 m), C39137

Fig. 1a spiral view

Fig. 1b umbilical view

Fig. 1c lateral view

sample W-20, "Marnes á Cyrènes", Late Rupelian (scale 100 um), C39054

Fig. 2a spiral view

Fig. $2 \mathrm{~b}$ lateral view

Fig. 2c umbilical view

Globigerinatheka micra (SHUTSKAYA)

sample Retzwiller sandig, "Marnes á Cyrènes", Late Rupelian (scale 100 m), C39139

Fig. 3a spiral view

Fig. $3 \mathrm{~b}$ oblique lateral view

Fig. 3c apertural view

Globigerinatheka semiinvoluta (KEIJZER)

sample Retzwiller sandig, "Marnes á Cyrènes", Late Rupelian (scale $100 \mu \mathrm{m}$ ), C39135

Fig. 4a spiral view

Fig. 4b umbilical view

Fig. 4c lateral view

Chiloguembelina midwayensis (CUSHMAN)

sample A-23, "Marnes á Cyrènes", Late Rupelian (scale 50 m), C39345

Fig. 5 lateral view

Chiloguembelina wilcoxensis (Cushman \& PONTON)

sample A-34, "Couches à Melettes", Late Rupelian (scale $50 \mu \mathrm{m}$ ), C39147

Fig. 6a lateral view

Fig. 6b peripheral view

Chiloguembelina cubensis (PALMER)

striate form, sample Eguisheim-3, "Marnes á foraminiferes", early Late Rupelian (scale $50 \mu \mathrm{m}$ ), C39201

Fig. 7a lateral view

Fig. $7 \mathrm{~b}$ peripheral view

pustulate form, sample A-66, "Marnes á foraminiferes", early Late Rupelian (scale $50 \mu \mathrm{m}$ ), C39038

Fig. 8 lateral view

Tenuitella munda (JENKINS)

sample W-25, "Marnes á Cyrènes", Late Rupelian (scale 100 um), C39121

Fig. 9a spiral view

Fig. 9b umbilical view

Fig. 9c lateral view

Tenuitella gemma (JENKINs)

sample Retzwiller-1, "Marnes á Cyrènes", Late Rupelian (scale $100 \mu \mathrm{m}$ ), C39305

Fig. 10a, b spiral views

Fig. 10c lateral view 


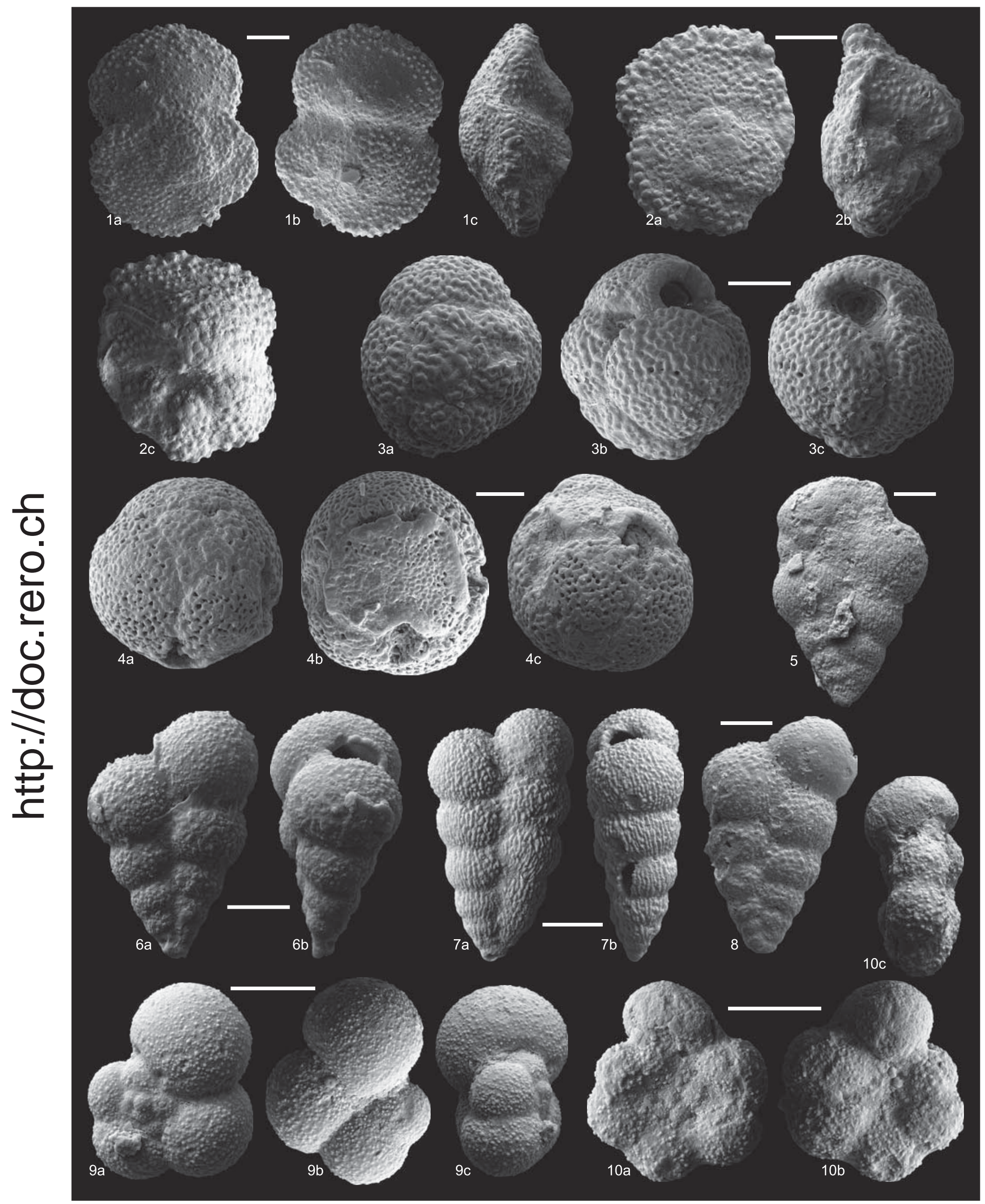




\section{Plate 16}

Eo-Oligocene planktonic Foraminifera

Globigerina ciperoensis BOLLI

sample W-45, “Couches á Melettes”, Late Rupelian (scale 100 m), C39081

Fig. 1a spiral view

Fig. $1 b \quad$ umbilical view

Fig. 1c lateral view

Globigerina praebulloides BLOw

sample A-36, “Couches á Melettes”, Late Rupelian (scale 50 m), C39242

Fig. 2a spiral view

Fig. $2 b \quad$ umbilical view

Fig. 2c lateral view

twin, sample A-42, “Couches á Melettes”, Late Rupelian (scale 100 um), C39236

Fig. 3a spiral view

Fig. 3b "umbilical" view

"Globigerina" venezuelana HedBerG

sample W-20, "Marnes á Cyrènes", Late Rupelian (scale $100 \mu \mathrm{m}$ ), C39055

Fig. $4 a$ spiral view

Fig. $4 \mathrm{~b}$ umbilical view

Fig. 4c lateral view

"Zeaglobigerina" ampliapertura (BOLLI)

sample A-03, "Molasse alsacienne”, Early Chattian, reworked (scale $100 \mu \mathrm{m}$ ), C39034

Fig. 5 a spiral view

Fig. 5 b umbilical view

Fig. 5c lateral view

Zeaglobigerina sp. 1

sample A-74a, basal “Marnes á foraminifères”, early Late Rupelian (scale $100 \mu \mathrm{m}$ ), C39331

Fig. 6a spiral view

Fig. $6 \mathrm{~b}$ umbilical view

Fig. 6c lateral view

Subbotina angiporoides (HORNIBROOK)

sample A-39, “Couches á Melettes”, Late Rupelian (scale $100 \mu \mathrm{m})$, C39332

Fig. 7a spiral view

Fig. $7 \mathrm{~b}$ umbilical view

Fig. 7c lateral view

Subbotina eocaena (GUEMBEL)

sample A-15, “Marnes á Cyrènes”, Late Rupelian (scale 100 m), C39267

Fig. 8a spiral view

Fig. $8 \mathrm{~b}$ umbilical view

Fig. 8c lateral view 


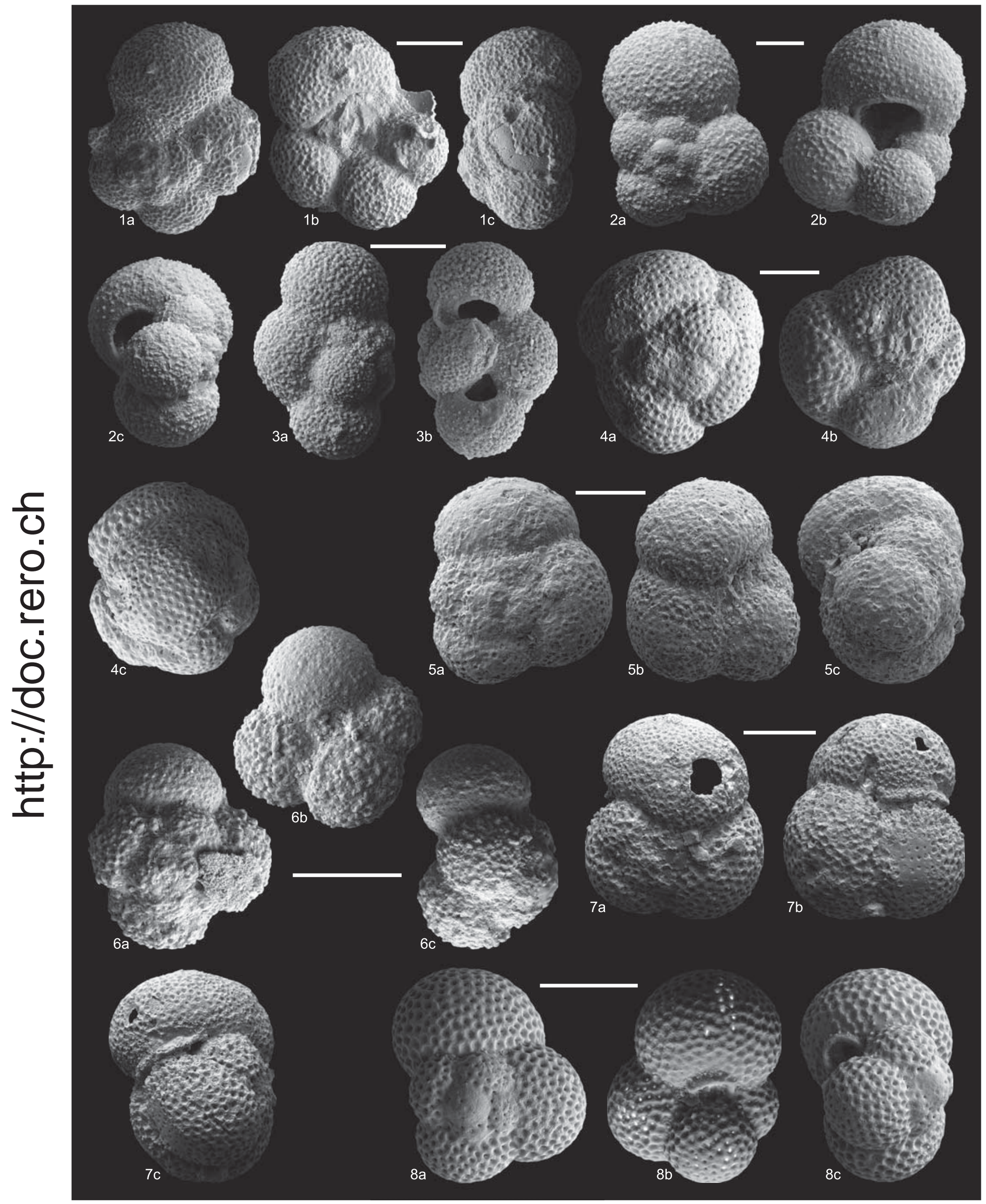


Plate 17

(scale $100 \mu \mathrm{m}$ )

Subbotina gortanii (BORSETTI)

sample W-20, "Marnes á Cyrènes", Late Rupelian, C39064

Fig. 1a spiral view

Fig. 1b umbilical view

Fig. 1c lateral view

Subbotina utilisindex (JENKINS \& ORR)

sample A-03, "Molasse alsacienne", Early Chattian, C39087, C39246

Figs. 2a, 3a spiral view

Figs. $2 \mathrm{~b}, 3 \mathrm{~b}$ umbilical view

Figs. 2c, 3c lateral view

Globigerinella obesa (D'ORBIGNY)

sample A-70, "Marnes á foraminifères", early Late Rupelian, C39219

Fig. $4 a$ spiral view

Fig. 4b umbilical view

Fig. 4c lateral view

Pseudohastigerina barbadoensis BLow

sample A-23, "Marnes á Cyrènes", Late Rupelian, C39341

Fig. 5a spiral view

Fig. 5b lateral view

Pseudohastigerina micra (COLE)

sample A-23, "Marnes á Cyrènes", Late Rupelian, C39264

Fig. 6a spiral view

Fig. 6b lateral view

Paragloborotalia nana (BOLLI)

sample A-34, "Couches á Melettes", Late Rupelian, C39097

Fig. 7a spiral view

Fig. 7b umbilical view

Fig. $7 \mathrm{c}$ lateral view

Paragloborotalia cf. nana (Bolli)

sample Retzwiller-1, "Marnes á foraminiferes", early Late Rupelian, C39248

Fig. 8a spiral view

Fig. $8 \mathrm{~b}$ umbilical view

Fig. $8 c$ lateral view 


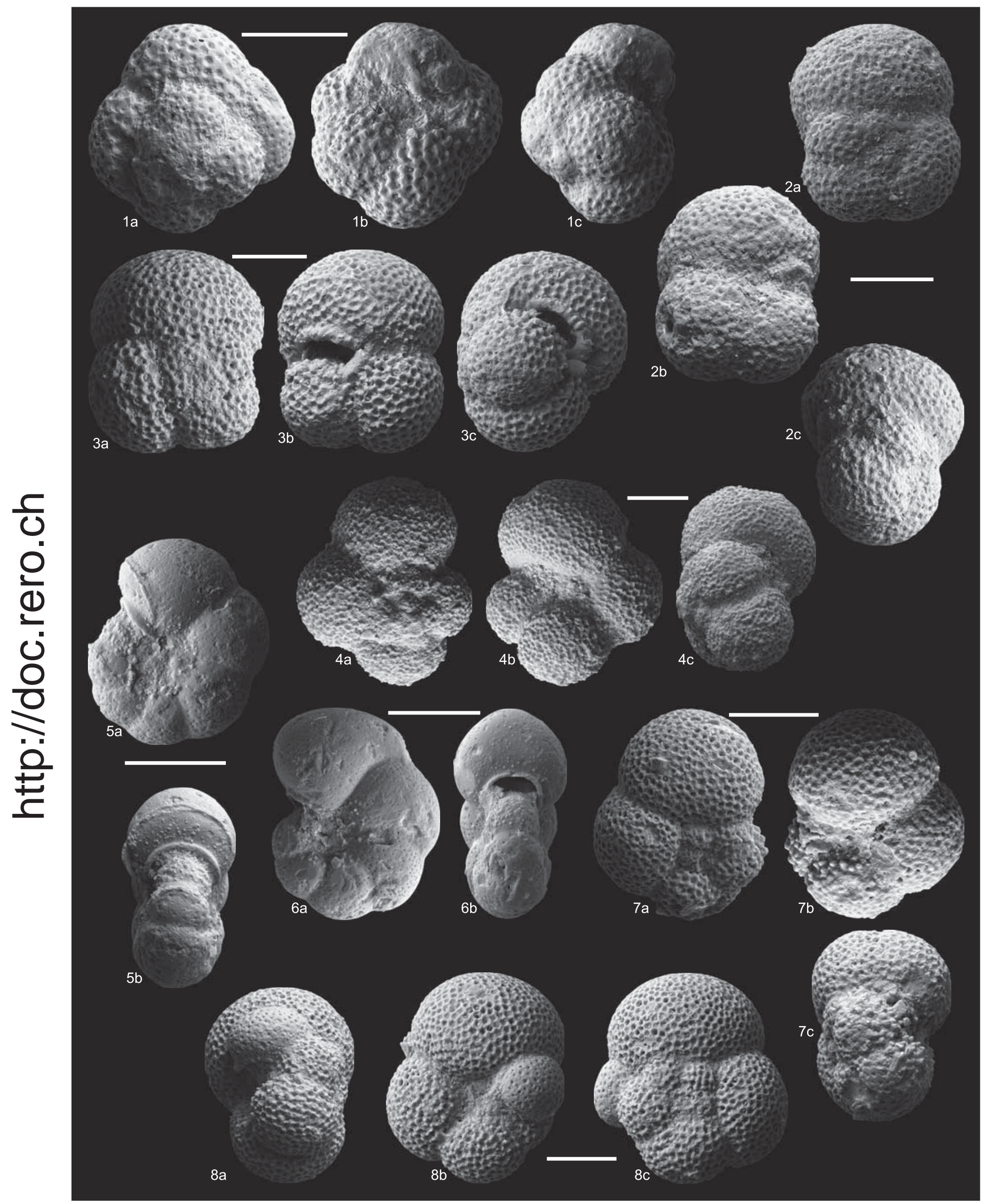




\section{Plate 18}

Acarinina echinata [Catapsydrax echinatus] (BOLLI)

with bulla, sample Eguisheim-3, "Marnes á foraminiferes”, early Late Rupelian (scale $50 \mu \mathrm{m}$ ), C39198

Fig. 1a spiral view

Fig. $1 \mathrm{~b}$ umbilical view

Fig. 1c lateral view

without bulla, above sample (scale $50 \mu \mathrm{m}), \mathrm{C} 39206$

Fig. 2a spiral view

Fig. $2 \mathrm{~b}$ umbilical view

Fig. 2c lateral view

Catapsydrax martini (BLOW \& BANNER)

sample W-45, “Couches á Melettes”, Late Rupelian (scale 100 um), C39080

Fig. 3a spiral view

Fig. $3 \mathrm{~b}$ umbilical view

Fig. 3c lateral view

Catapsydrax unicavus BolLI, LOEBLICH \& TAPPAN

sample Retzwiller sandig, "Marnes á foraminifères”, early Late Rupelian (scale 100 m), C39282

Fig. $4 a$ spiral view

Fig. $4 \mathrm{~b}$ umbilical view

Fig. 4c lateral view

Globorotaloides cf. carcoselleensis ToumARKINE \& BOLLI

sample W-45, "Couches á Melettes”, Late Rupelian (scale $100 \mu \mathrm{m})$, C39126

Fig. 5a spiral view

Fig. 5b umbilical view

Fig. 5c lateral view

Globorotaloides variabilis BOLLI

sample A-40, “Couches á Melettes”, Late Rupelian (scale $50 \mu \mathrm{m}$ ), C39240

Fig. 6a spiral view

Fig. $6 \mathrm{~b}$ umbilical view

Fig. 6c lateral view

Dentoglobigerina cf. galavisi (LERoy)

sample W-23, "Marnes á Cyrènes”, Late Rupelian (scale 100 m), C39118

Fig. 7a spiral view

Fig. $7 \mathrm{~b}$ umbilical view

Fig. 7c lateral view 

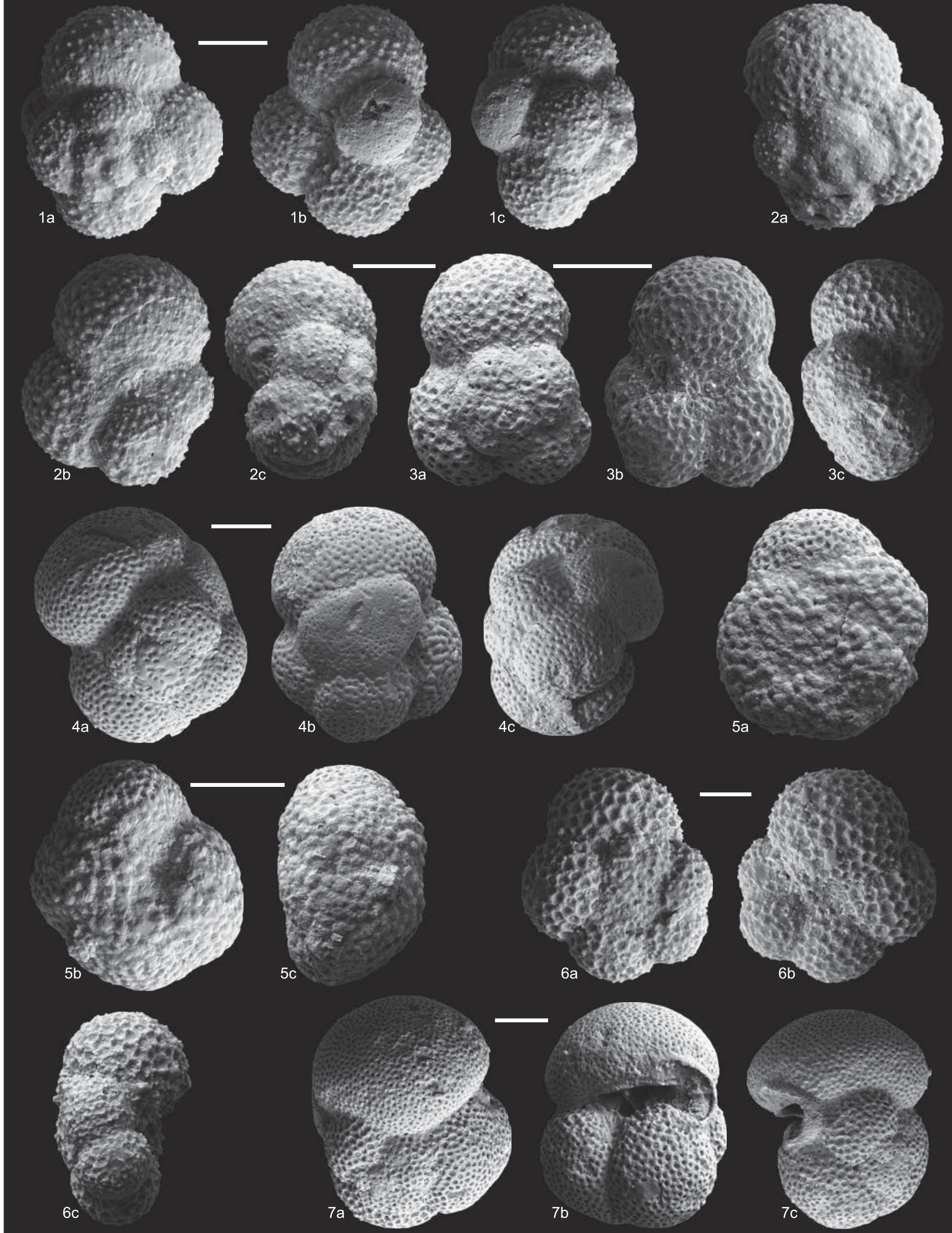